\title{
IIDAKA, T., A Comparative Study of Body Structure of Nisei of Native Japanese.
}

\section{米國生れ二世の体格成績ミ日本人この比䡌}

\section{第 1 編 米國生れ二世の体格調查成績}

指溥石原房雄

飯高歲子

\section{藉管}

両親共日本人で米国て生れ且発育した二世 の体格に就て研究されたものは, 吉田章信博 士がハワイの二世の小学校児童 2,321 名の体 格に就て委啒調查したるのか最初であつて， 其成績によると，その身長，体重，ともに內地 の児童より優秀であることを指摘されたのが 1922 年で，それがたら気候や栄䓹がよいため に早熟したものではないかとの疑問をるたれ 終局体格の壯丁に於てとうであ万うかとの疑 問をとくために石原は 19 才以上26才迄の253 に就て調查したのか; 1930 年で，ややはり內地人 に比して身長，体重の绿秀，特に下肢長の長 いことを指摘した。っつて石原指導のるとに ロスフンヂルス市に於て蕦々木栄博士が二世 の学童 2,583 名に就て 1931 年加 5 ヶ年間其 休格を調查し，さきに吉田博士の示した数字 以上に優秀さ哮しその発育は米国人の览童 の発育と㱠んと等しいこと存示した。ロスフ ンヂルス市の壮藤氏は溉々榑士の示股の下 にロスアンヂルス市にて202名の新生児の体 格を調く，次で成年女子の体格を詳細侸研究 しこれも文內地のものに比し優秀で, 殆んを 米国人と同し身長，体重を示したのであつた。 (1936 年) 細加い数字は後に諨り二世の体格 は出赽時既にすぐれて,発育も米国人に劣らな い数字を示しているか，份その終局の体位に 就て如何なる美異を示しているか，殊に身長 の長いのは下肢長が長いのに原因するもの了
如く石原は称えたか，佾これを追試する必要が あり, 坐高, 上肢長, 頭部, 皮厚等に就ては いまだ实際の計測がいので，これをる湘定 し, 二世の体格が日本內地人の体格と如何な る部位か違うか子比較研究することは，日本 人の体格をとれまで発展せしめ得るか子る知 ることを得るもので，極めて重要なことであ る。殊に石原の報告に低れば二世か一挙に身 長 9.3 㱫る伸びだ列を示している。

F. Boas 氏（1910.年）は東欧へブライ人が 米国に移住せしるのが身長伂 1.5 糎大, 体重 0.6 躯增大していることを報告したが、シシリ 一島から米国に移住した昌童は身長，体重共 に小さくなったことを報告した。るれ故に身 長 $4 \%$ ，体軍 $13 \%$ を伂びた例はないのて - Pearson 氏梳これ杜実に Epockmaking in anthropology であると兴したのである。幸 に目下日本に多数の二世淮䮃して潜在して いるので，之等の人の体格を検查出來れば，絶 好の機会であると思い，総司令部のションy 二大佐に研究の主旨を述へたら，それは日本人 の天赋の体格索検討するに梁架な問題である 加ら進駐軍として調查しょうと, 去る昭和 24 年 12 月郵船ビルの中で進駐軍人及び軍属の体 格を調查した。此等の人は軍属か７分て軍人か; 3 分位である。軍属と日光ば一般の人ょり優 秀な様に思われるが実際は病気てないものは 全部徵兵されているし，体格検查もほんの形 式的のものであり, 其冈に正規軍人は除かれて 
いるのであるから，二世--般の成績よりいく らか惡いと思われる。文検查の結果を見ても 従來の二世の結果に比較してや了劣つている のを見ても領かれる。計測は258名の男子で 20 才ょり 30 才のものがまをのであつた。 計测事項は身長, 体重, 胸囲, 上肢長, 下肢長, 坐高, 上脯团, 頭長, 頭幅, 皮厚等 の 10 項目をマルチンの㳂則により計测した。 倘日本の出身地, 現住所, 腤湿, 父母の身長, 体重等を記入して鿓つた。二世の体格の優 秀なのは両親の体格が地の人ょり優れて いるのではないか，殊に渡米の際には一応の 体格検查もあるからである。二世は両親の身 長，体重は相当正碓に記憶しているものであ つた。

集計には全部の者の平均を求めた外に，米

第 1 表 被檢者年 令

\begin{tabular}{|c|c|c|c|c|}
\hline \multirow{2}{*}{ 年 令 } & \multicolumn{2}{|c|}{ 員 } & \multicolumn{2}{|c|}{ 數 } \\
\hline & 日 本 & ハワイ & 米 國 & 詁 \\
\hline 18〜20才 & 1 & 4 & 7 & 12 \\
\hline $21 \sim 25$ & 5 & 33 & 37 & 75 \\
\hline $26 \sim 30$ & 7 & 31 & 65 & 103 \\
\hline $31 \sim 35$ & 7 & 9 & 34 & 50 \\
\hline $36 \sim 40$ & 1 & 4 & 7 & 12 \\
\hline $41 \sim 45$ & 2 & 0 & 2 & 4 \\
\hline $46 \sim 49$ & 0 & 1 & 0 & 1 \\
\hline 不时 & 0 & 0 & 1 & 1 \\
\hline 計 & 23 & 82 & 153 & 258 \\
\hline
\end{tabular}

統計 記號

$$
\mathrm{n}=\text { 員 數 }
$$

$\mathrm{M}=$ 算随平均

$\sigma=$ 標準 偏豦

$\mathbf{m}=$ 算衡平均の平均洖差

$\mathbf{m} \sigma=$ 標準偏差の平均器差

$\mathrm{V}=$ 變巽係數

$\mathrm{mV}=$ 變照係數つ平均誤差

墢育地の記號

全は總平均 米は米大陸內吃於て發育せ しもの八ワイは同島伦於て發育せしも の 日本は或期聞日本の內地飞て發育せ しすの
大陸で発育した者と，ハワイで発育した者と， 成育の中涂数年間を日本で発育した者とを別 に集計した。これはさきに石原か発表したも ので米大陸の者と，ハワイの者とは寚があつた

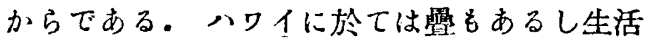
様式が純米式より多少違つているからである

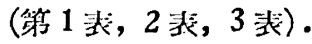

内地人の標淮としては文部省, 陸軍省等色 々の訐測值を用いたが就中慶応大学谷口教授 の許で玉井, 塚田両博士の東京在住の関東配 電の從業員を調查したものと比較した。これ は調查項目が多く, 且日朴全地区の人か; 網檌 されているからである。只労務者があるからら 体格仙広身型が多い軀わある

又移民による影響を調查した郝告には，満 洲に移民した人の子供の発育について 関東庁 体育研究所の報告があり，又㴚田氏は台湾に 於ける內地人，及野田氏，塚田氏の南洋に成 育せる日本人及び混血児の報告がありり，江口 氏のサイバン島に於けるもの，池氏のマリフ ナ島に於けるものがあるので之等と比较し た。

\section{第 1 節 身長に就て}

二止全体の 身長平均は 165.5 糎である。こ れは石原の 276 名の 全米国の本均は 166.3 粧 と比较すると 0.8 糖の芸があるだけである。 其理的は石原のものは，一定期間日本で大き くなつたものはなく，都术生活者ばかりであ つたからである。今度のは月本で或期間大きく なつたものや，田舍の人，農夫等も皆集計した し,正規の策人は少ないのであるから当然の坡 である. Хハワイの 82 名の平均は 166.1 糎で ある. 石原がさきに計测したハワイの93名の 身長平均は 164.9 粝であつたから 1.2 糎大きく なつている。（石原のちのは夕刻の测定である から少し小さくなつていると思われる)文同し 二世で一定期闑日本內地で成育した者の平均 は 164.5 糎てある・日本での年数は明記されて 
第 2 表

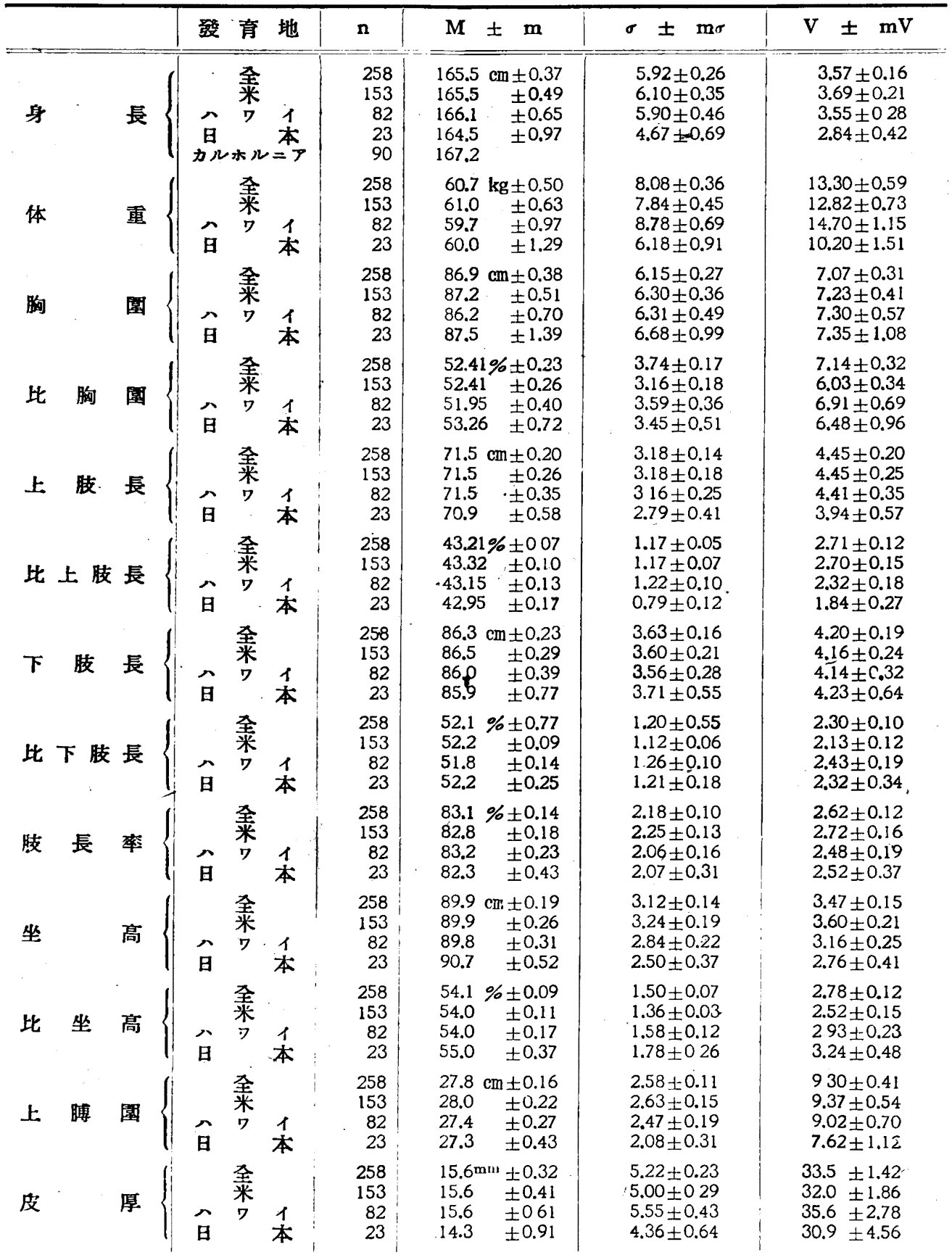




\begin{tabular}{|c|c|c|c|c|c|c|c|c|}
\hline & & 墢 & 育 & 地 & $\mathbf{n}$ & $\mathbf{M} \pm \mathbf{m}$ & $\sigma \pm \mathbf{m} \boldsymbol{\rho}$ & $\mathbf{V} \pm \mathbf{m V}$ \\
\hline 口 指 & 數 & 合 & $\begin{array}{l}\text { 奎 } \\
\text { 来 } \\
\text { ワ }\end{array}$ & 京 & $\begin{array}{r}258 \\
153 \\
82 \\
23\end{array}$ & $\begin{array}{lr}134.4 & \% \pm 10.8 \\
136.4 & \pm 1.48 \\
131.0 & \pm 1.88 \\
135.5 & \pm 3.16\end{array}$ & $\begin{array}{l}17.47 \pm 0.77 \\
18.27 \pm 1.04 \\
17.10 \pm 1.33 \\
15.16 \pm 2.24\end{array}$ & $\begin{array}{l}13.08 \pm 0.58 \\
18.25 \pm 1.03 \\
13.05 \pm 1.01 \\
11.18 \pm 1.65\end{array}$ \\
\hline 頭 & 長 & 合 & $\begin{array}{l}\text { 㝨 } \\
\text { 米 } \\
\text { ワ }\end{array}$ & 本 & $\begin{array}{r}258 \\
153 \\
82 \\
23\end{array}$ & $\begin{array}{ll}18.64 \mathrm{~cm} & \pm 0.05 \\
18.76 & \pm 0.06 \\
18.41 & \pm 0.08 \\
18.74 & \pm 1.27\end{array}$ & $\begin{array}{l}0.74 \pm 0.03 \\
0.74 \pm 0.04 \\
0.72 \pm 0.05 \\
0.61 \pm 0.18\end{array}$ & $\begin{array}{l}3.99 \pm 0.18 \\
3.94 \pm 0.23 \\
3.94 \pm 0.31 \\
3.26 \pm 0.48\end{array}$ \\
\hline 頭 & 偪 & 全 & $\begin{array}{l}\text { 全 } \\
\text { 米 } \\
\text { ワ }\end{array}$ & $\begin{array}{l}1 \\
\text { 米 }\end{array}$ & $\begin{array}{r}258 \\
153 \\
82 \\
23\end{array}$ & $\begin{array}{l}15.89 \mathrm{~cm} \pm 0.04 \\
15.90 \pm 0.06 \\
15.89 \pm 0.07 \\
15.89 \pm 0.13\end{array}$ & $\begin{array}{l}0.65 \pm 0.03 \\
0.68 \pm 0.04 \\
0.60 \pm 0.05 \\
0.63 \pm 0.09\end{array}$ & $\begin{array}{l}409 \pm 0.18 \\
4.25 \pm 0.24 \\
3.76 \pm 0.29 \\
3.97 \pm 0.59\end{array}$ \\
\hline 頭 & 率 & 香 & $\begin{array}{l}\text { 全 } \\
\text { 米 } \\
\text { ワ }\end{array}$ & $\begin{array}{c}1 \\
\text { 本 }\end{array}$ & $\begin{array}{r}258 \\
153 \\
82 \\
23\end{array}$ & $\begin{array}{l}85.21 \% \pm 0.24 \\
85.0 \quad \pm 0.38 \\
86.4 \quad \pm 0.46 \\
84.7 \quad \pm 0.78\end{array}$ & $\begin{array}{l}3.86 \pm 0.17 \\
4.67 \pm 0.27 \\
4.17 \pm 0.33 \\
3.73 \pm 0.55\end{array}$ & $\begin{array}{l}4.52 \pm 0.20 \\
5.50 \pm 0.31 \\
4.83 \pm 0.38 \\
4.40 \pm 0.65\end{array}$ \\
\hline
\end{tabular}

第 3 表 (總括表)

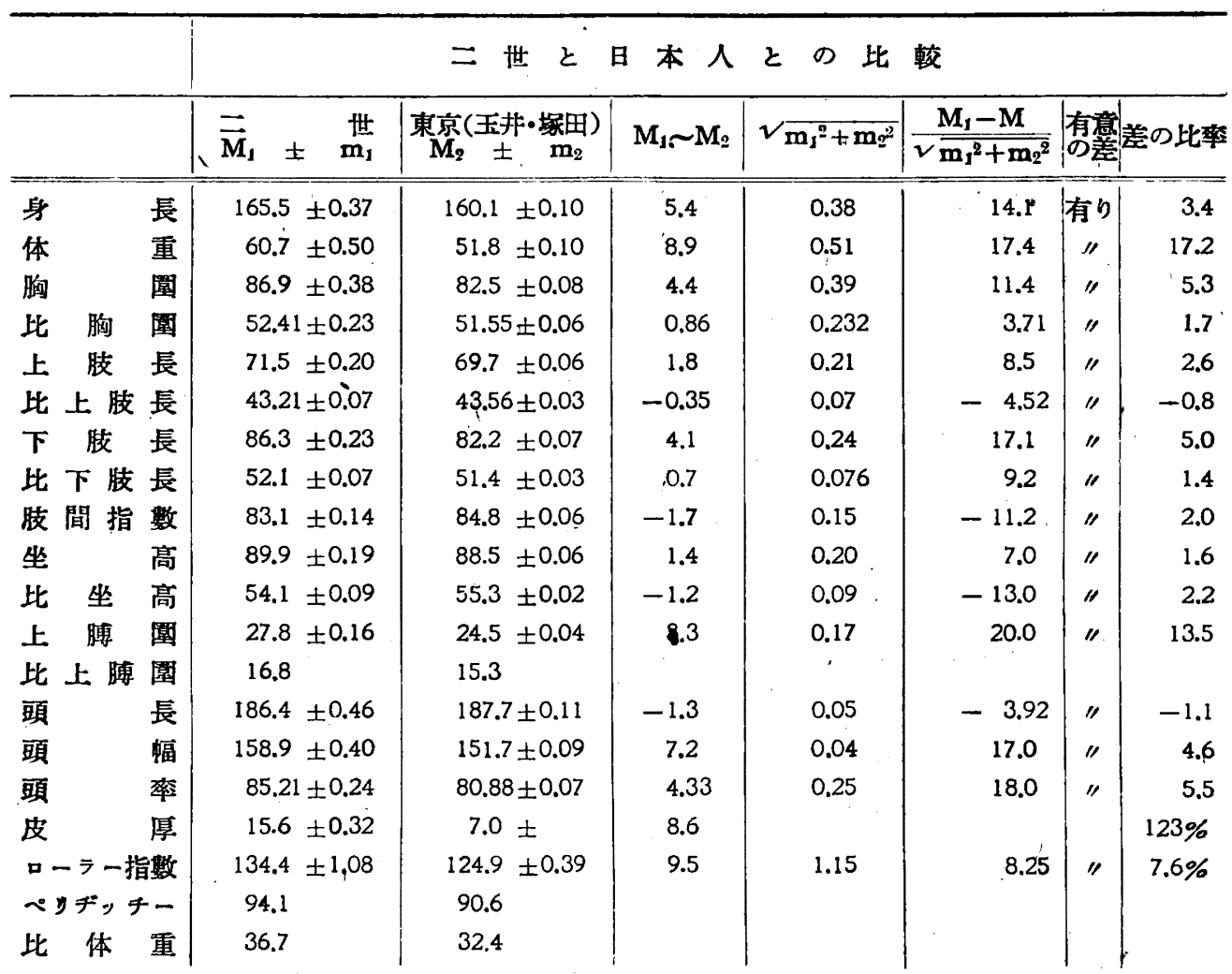




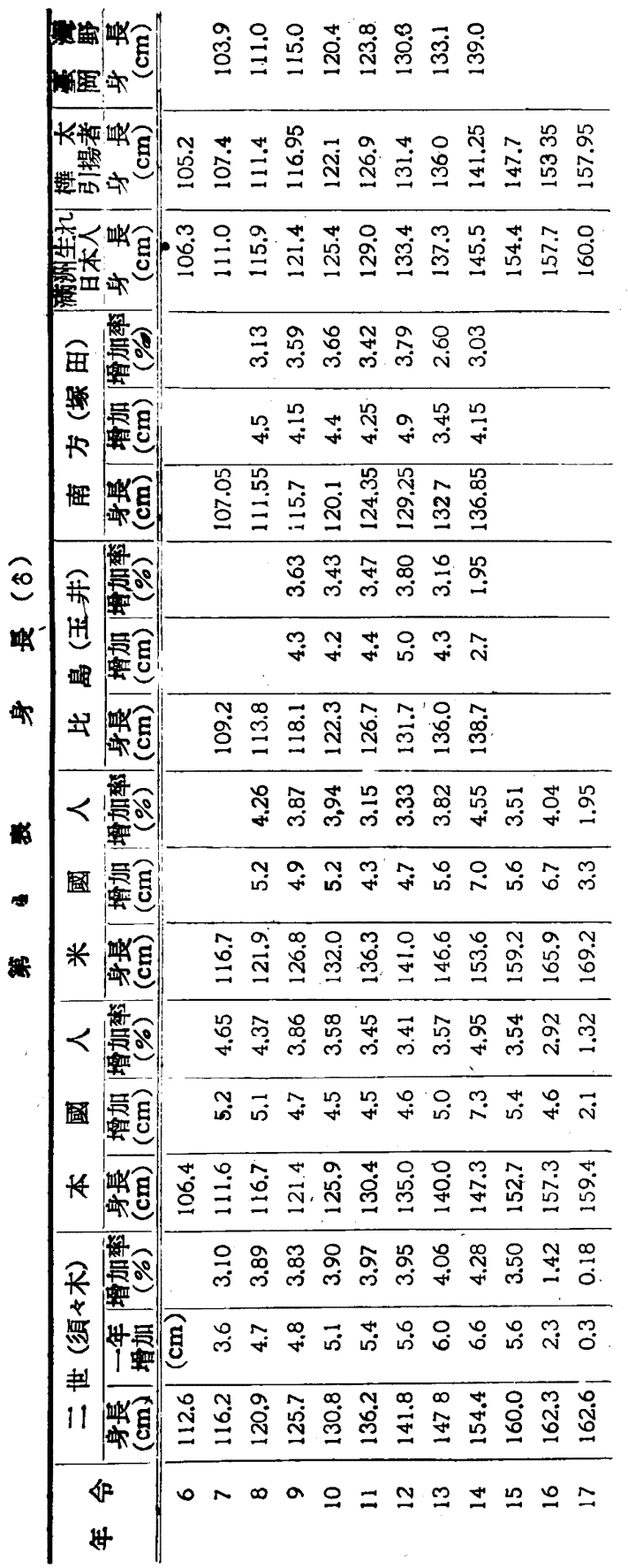

\begin{tabular}{|c|c|c|}
\hline & 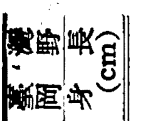 & 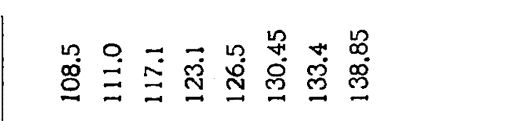 \\
\hline & 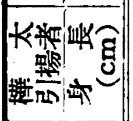 & 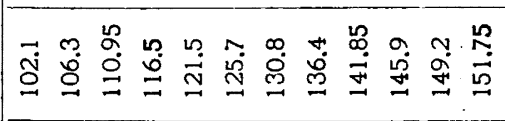 \\
\hline & 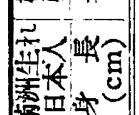 & 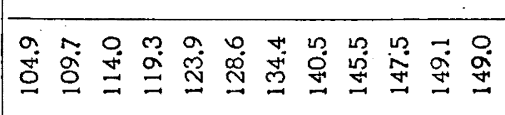 \\
\hline & 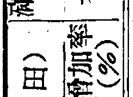 & 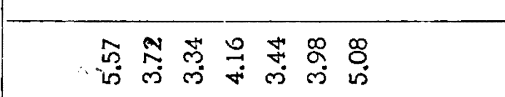 \\
\hline & 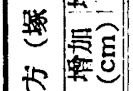 & 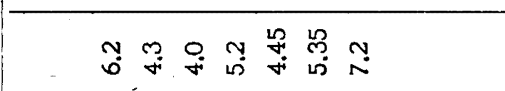 \\
\hline & 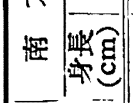 & 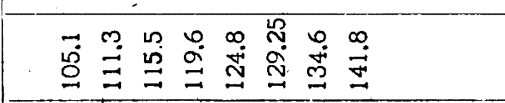 \\
\hline & 琣领 & 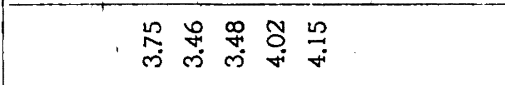 \\
\hline & 樆鸹 & 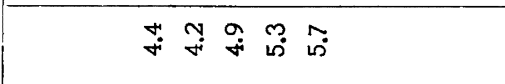 \\
\hline & 紫窇 & 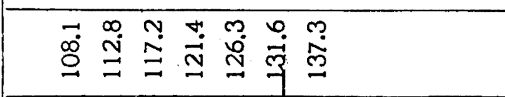 \\
\hline & 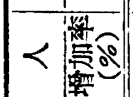 & 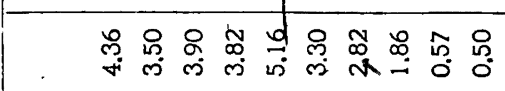 \\
\hline & 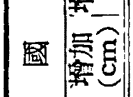 & 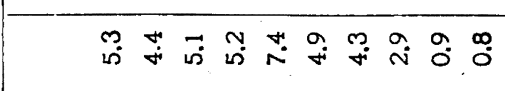 \\
\hline & * 整息 & 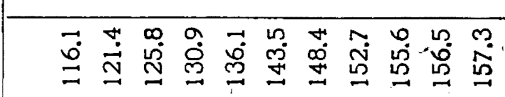 \\
\hline & 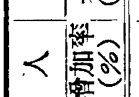 & 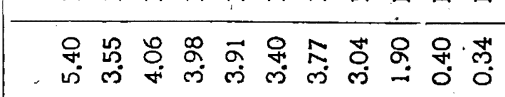 \\
\hline & 国套殉 & 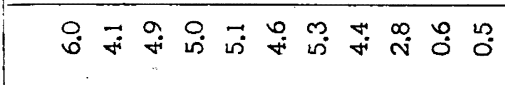 \\
\hline & * & 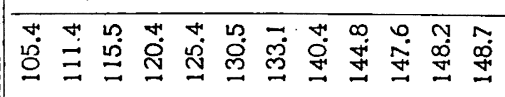 \\
\hline & 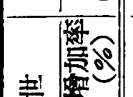 & 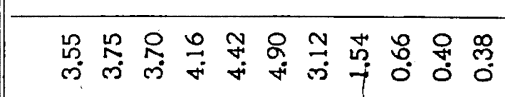 \\
\hline & 4 & 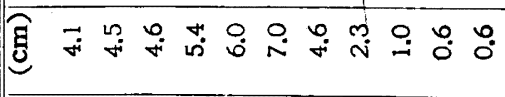 \\
\hline & 11 & 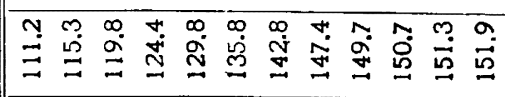 \\
\hline & \$ & \\
\hline
\end{tabular}


いないのか多く大体は数年らしいがそれが 身長平均 1.0 糎小さいという事は注意すべき 事である。石原がロスアンヂルフ市內の 104 名の平均は 169.5 糎で著しく大であるがこ 了に今度計测した二世の內からカリフォル ニア洲の人だけ 90 名を別に集計してみたが其 平均は 167.2 糎で, 全体平均より 1.7 糎大であ る。其內にロスフンヂルス市內のものは僅か に7名である. 且今回はハワイの人が多く3
分の 1 に澾しているから，さきに調へた石原 のはロスフンヂルス市,シフトル市內の人のみ であつたから此差を見たのであるが，倘かリ フォナルニア洲は気候や生活がよいと見えて全 体の本均より 1.7 糎大である. Shapiro 氏の ハワイ二世 70 余名の本均は，162.53 粝で 3.6 糎小である.1939年のもので，年代の差であ ろう（第 4,5 表, 第 1 図).

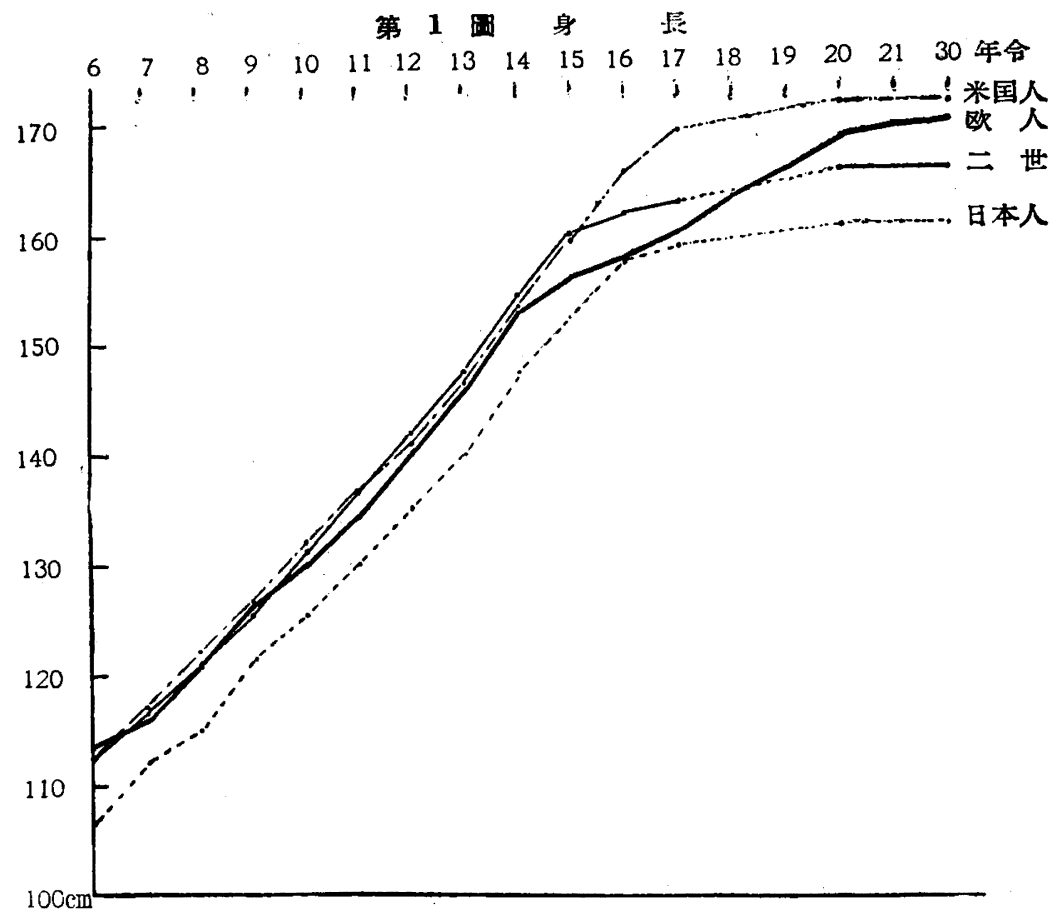

身長は瞳籍, 貧富, 地域別, 都市と農山村, 潐村により差がある.Pitzner は下䄲官吏，中 流, 富者を比較して身長 3 4 粝の差を示すと 第 6 表に表示した。又年代によつても違う。世 界各国共 10 ケ年に $0.1 \sim 0.5$ 糎位伸びているこ とを注意しなければならね。職禁により其差 も著しいもので，一番身長の長いのは專䅀学 校, 大学の学徒で,一般より 4 糎队外大である ことは英, 米, 伊, 佛の下記の統計の示す所日 本も同しである. 又陸上選手る亦大である。
吉田博士の砛究によれば 6 13 糎大である. 又都市と農村によつても差がある。都市の生 活者は農村に比して 2 粝位大であり，労務者 でも外労務者は稍々大きく漁夫等は大きい。 昭和 6 年 10 年陸軍省全国壯丁本均 は 160 糎である. 又第 7 裴に示すが如く矢ケ崎, 村 田, 古屋氏等 24 名の計测値を本均してみると 159.97糎であつて二壮はこれに比して 5.5 湹 大である，塚田博士の東京都在佳会社員の平 均 160.1 糎に比すれば 5.4 粧大であう。今二世 


\begin{tabular}{|c|c|c|c|c|c|c|c|c|c|}
\hline & & & & 第 & 衰 & & & & \\
\hline & \multicolumn{3}{|r|}{$\hat{\delta}$} & 体 & 目 & & \multicolumn{2}{|c|}{ 身 } & 長 \\
\hline & & I (富者) & II & $\begin{array}{l}\text { 中位官耚 } \\
\text { 俸給 者 }\end{array}$ & 中位工場主) & $\prod_{(\mathrm{s}}$ & I & II & III \\
\hline \multirow{2}{*}{ 年 } & $2 \sim 3$ お & 13.7 & 12.3 & & & 11.8 & 88.6 & 86.2 & 84.6 \\
\hline & $3 \sim 4$ & 15.2 & 14.5 & & & 13.7, & 96.5 & 94.7 & 91.1 \\
\hline \multirow{2}{*}{ 令 } & $4 \sim 5$ & 18.9 & 15.6 & & & 15.4 & 107.1 & 98.9 & 97.4 \\
\hline & $5 \sim 6$ & 19.5 & 17.9 & & & 17.7 & 109.9 & 106.4 & 106.7 \\
\hline
\end{tabular}

大學生と勞務者と夷の表を見る（身長）

\begin{tabular}{|c|c|c|c|c|}
\hline & 英國人 (Roberts) & 佛 人 (Longuet) & 伊人（Livi） & 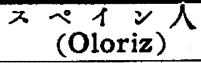 \\
\hline 專門大學 \&生 & $172.4 \mathrm{~cm}$ & 168.7 & 166.9 & 163.9 \\
\hline 勞 務 者 & 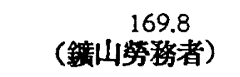 & （日 佊 $\stackrel{164.4}{\text { 人) }}$ & 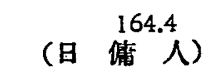 & $\begin{array}{c}159.8 \\
\text { (工場勞務者) }\end{array}$ \\
\hline
\end{tabular}

第 7 表

\begin{tabular}{|c|c|c|c|}
\hline 地 域 & 著 & 者 & 身 長 cm \\
\hline 越 中 & （矢 & 渏） & 158.41 \\
\hline 東海日本人 & （村 & 田） & 158.96 \\
\hline 北陸地方人 & （古 & 屋) & 160.33 \\
\hline 金澤市人 & （安 & 藤） & 158.01 \\
\hline 加賀富耎地人 & （安 & 藤） & 158.45 \\
\hline 我 彈 人 & （加 & 藤） & 158.60 \\
\hline $\begin{array}{l}\text { 標 準 体 格 } \\
\text { (專大學々生) }\end{array}$ & （西 & & 164.4 \\
\hline 北陸部落㞎 & （安 & 藤） & 159.50 \\
\hline 金澤市郵便局員 & & 置） & 158.3 \\
\hline 薜摩 人 & （鮫島， & 加藤） & 162.29 \\
\hline 大隅 人 & （加藤， & 鮫島） & 162.23 \\
\hline 崦美大島人 & （加藤， & 鮫島） & 159.89 \\
\hline 琉 球 人 & (加藤， & 鮫島） & 161.96 \\
\hline 秋田縣人 & （中 & 山） & 158.20 \\
\hline 薹岐島人 & （小 & 濱） & 162.78 \\
\hline 對馬島人 & （小 & 演） & 162.03 \\
\hline 南九洲人 & （小 & 演） & 159.02 \\
\hline 近㼄地方人 & （中 & 山) & 164.73 \\
\hline 土佐 人 & （上 & 田） & 160.76 \\
\hline 大分 縣 人 & （西 & 岡) & 157.84 \\
\hline 種子 & （伊 & 東) & 159.64 \\
\hline 屋 久 島 & （伊 & 東） & 158.64 \\
\hline 靑 森 縣 人 & （中 & 山) & 157.70 \\
\hline 平 & & & 159.97 \\
\hline
\end{tabular}

の示した 165.5 粝という数字は陸上競拔者の 平均より小さく，大学々生の平均より稍々大 きい数である。

次に此等二世の両親の体格に就て見ん。渡 米移住せんとすれば身体検查もあり両親の体 格が優秀であれば其子も聚秀なることは明ら かである。其父の 119 人の本均身長 161.4 糎 で內地の人にしては少し大きい方である.112 人の母の本均身長は 153.6 粝で內地 の平均 147.2 糎に比較すると 6.4 糎大である。即ち両 親共体格が大であつたことは二世の体格を大 ならしめた一原因であると思われる(第8 表). 石原が先年同様の調查した.99名の平均は父 159.9 粝, 母 154.6 粝で大体同じであつた。

向其発育と米国以外の地域に成育した人と の比較は後章に詳述した.向日本人と比較する 際注意しなければならぬことは，內地日本人 も地域により本均身長に差潼あるからである。 一般に近畿，中国，北九洲の人は身長大きく， 東北, 北陸, 南九洲は短身型で, 沖繩は最も 小である。今二世両親の出身地を見ると厷島 が最も多く $15 \%$ を占め, 次で和歌山, 福岡, 熊本，鹿児島，岡山等は5８\%で総して中国 $40 \%$, 沂幾 $21 \%$ ，九洲 $20 \%$ (北 $13 \%$, 南 $7 \%$ ) 其他であつて，長身型の地方の人か多い。こ 
茅 8 製

\begin{tabular}{|c|c|c|c|c|c|}
\hline & 弡 一育 地 & $\mathbf{n}$ & $\mathbf{M} \pm \mathrm{m}$ & $\sigma \pm \mathbf{m} \sigma$ & $\mathrm{v} \pm \mathrm{mv}$ \\
\hline 父の身長 & 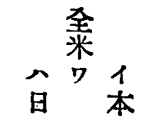 & $\begin{array}{r}119 \\
73 \\
34 \\
12\end{array}$ & $\begin{array}{lr}161.4 & \mathrm{~cm} \pm 0.54 \\
161.5 & \pm 0.73 \\
161.4 & \pm 0.99 \\
160.3 & \pm 1.03\end{array}$ & $\begin{array}{l}5.88 \pm 0.38 \\
6.23 \pm 0.52 \\
5.75 \pm 0.70 \\
3.57 \pm 0.73\end{array}$ & $\begin{array}{l}3.64 \pm 0.24 \\
3.86 \pm 0.32 \\
3.56 \pm 0.43 \\
2.23 \pm 0.46\end{array}$ \\
\hline 父の体重 & 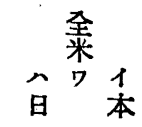 & $\begin{array}{r}104 \\
67 \\
29 \\
8\end{array}$ & $\begin{array}{ll}61.6 \mathrm{~kg} & \pm 0.76 \\
61.6 & \pm 1.03 \\
61.4 & \pm 1.54 \\
61.5 & \pm 2.23\end{array}$ & $\begin{array}{l}7.72 \pm 0.54 \\
8.46 \pm 0.73 \\
8.28 \pm 1.00 \\
6.29 \pm 1.57\end{array}$ & $\begin{array}{l}12.70 \pm 0.88 \\
13.75 \pm 1.19 \\
13.46 \pm 1.63 \\
10.25 \pm 2.58\end{array}$ \\
\hline 母の身長 & 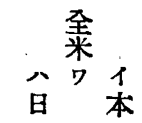 & $\begin{array}{r}112 \\
69 \\
32 \\
11\end{array}$ & $\begin{array}{ll}153.6 \mathrm{~cm} \pm 0.45 \\
153.6 & \pm 0.57 \\
152.8 & \pm 0.97 \\
154.2 & \pm 0.93\end{array}$ & $\begin{array}{l}5.00 \pm 0.33 \\
4.72 \pm 0.40 \\
5.48 \pm 0.68 \\
3.08 \pm 0.66\end{array}$ & $\begin{array}{l}3.25 \pm 0.22 \\
3.07 \pm 0.26 \\
3.59 \pm 0.45 \\
1.99 \pm 0.42\end{array}$ \\
\hline 母の体重 & 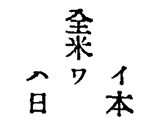 & $\begin{array}{r}98 \\
65 \\
\cdot 26 \\
7\end{array}$ & $\begin{array}{ll}53.4 \mathrm{~kg} & \pm 0.75 \\
53.0 & \pm 0.89 \\
55.2 & \pm 1.62 \\
50.4 & \pm 1.67\end{array}$ & $\begin{array}{l}7.42 \pm 0.53 \\
7.17 \pm 0.63 \\
8.26 \pm 1.15 \\
4.46 \pm 1.19\end{array}$ & $\begin{array}{r}13.90 \pm 1.00 \\
14.01 \pm 1.23 \\
14.95 \pm 2.07 \\
8.86 \pm 2.37\end{array}$ \\
\hline
\end{tabular}

れらも身長の大かつた原因の一つになるもの である。

\section{第 2 節 下肢長に就て}

下肢長の全平均は 86.3 糎で日本で一定期間 成育した人は稍々小さく 85.9 糎となつている. それを塚田博士の下肢長の 82.2 椻に比較する と 4.1 糎大である. 即ち身長の差 5.4 粝の內 4.1 粧 $(76 \%)$ は下肢長の長さによるものであ ることが解る．巽きに石原は身長の差 9.3 糎
あつたもの3，下肢長の差 8.3 框と云う数字 は 89\%であつた。須々木博士の児童の下肢長 を內地人と比較してみると第 7 表に示すが如 く二世は 各年令に於て 7 20才の本均 6.1 糎 は大で，身長の姜 6.0 糎の $100 \%$ か; 下肢長の 伸長に原因してるることがかかる。

比下肢長に就いてみても $52.1 \%$ ，內地の $51.4 \%$ に比較すると $0.7 \%$ の差だある．石原 が聂きにロスフンヂルス市民104名に就て調

第 9 表 坐高 $(\delta)$

\begin{tabular}{|c|c|c|c|c|c|c|c|c|c|c|c|c|c|c|c|}
\hline \multirow[b]{2}{*}{ 合 } & \multicolumn{2}{|l|}{$=$} & 世 & \multicolumn{2}{|l|}{ 本 } & 人 & 米 & 國 & 人 & \multicolumn{2}{|c|}{1 比 } & 島 & \multicolumn{2}{|c|}{ 南 } & 方 \\
\hline & $\mid$ & $\begin{array}{l}\text { 年之 } \\
\text { 增加 } \\
\text { (cm) }\end{array}$ & $\begin{array}{l}\text { 電 } \\
\text { 啐。 }\end{array}$ & 坐高 & $\begin{array}{c}\text { 霬加 } \\
\text { (c) }\end{array}$ & 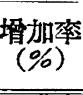 & $\begin{array}{l}\text { 坐高 } \\
(\mathrm{cm})\end{array}$ & $\begin{array}{c}\text { 㻥加 } \\
(\mathrm{cm})\end{array}$ & $\begin{array}{c}\text { 塉加率 } \\
(\%)\end{array}$ & $\begin{array}{l}\text { 坐高 } \\
\text { (cm) }\end{array}$ & $\begin{array}{c}\text { 䜖加 } \\
(\mathrm{cm})\end{array}$ & $\mid$\begin{tabular}{c|} 
增加率 \\
$(\%)$
\end{tabular} & $\begin{array}{l}\text { 坐高 } \\
(\mathrm{cm})\end{array}$ & $\begin{array}{l}\text { 增加 } \\
\text { (cm) }\end{array}$ & $\mid$ \\
\hline 6 & 66.1 & & & 64.2 & & & & & & & & & & & \\
\hline 7 & 64.9 & & & 66.2 & 2.0 & 3.02 & 63.8 & & & & & & 61.3 & & \\
\hline 8 & 66.2 & 1.3 & 1.96 & 67.9 & 1.7 & 2.50 & 66.0 & 2.2 & 3.33 & 63.8 & & & 63.3 & 2.0 & 3.16 \\
\hline 9 & 68.4 & 2.2 & 3.22 & 69.2 & 1.3 & 1.88 & 68.0 & 2.0 & 2.94 & 65.6 & 1.8 & 2.74 & 65.2 & 1.9 & 2.91 \\
\hline 10 & 70.6 & 2.2 & 3.12 & 71.8 & 2.6 & 3.62 & 69.8 & 1.8 & 2.58 & 67.4 & 1.8 & 2.68 & 67.0 & 1.8 & 2.69 \\
\hline 11 & 72.7 & 2.1 & 2.89 & 73.7 & 1.9 & 2.58 & 71.5 & 1.7 & 2.38 & 69.1 & 1.7 & 2.46 & 68.75 & 1.75 & 2.55 \\
\hline 12 & 74.8 & 2.1 & 2.81 & 76.1 & 2.4 & 3.14 & 73.3 & 1,8 & 12.46 & 71.3 & 2.2 & 3.09 & 70.4 & 1.65 & 2.38 \\
\hline 13 & 77.8 & 3.0 & 3.85 & 77.9 & 1.8 & 2.32 & 75.5 & 2.2 & 2.92 & 73.2 & 1.9 & 2.60 & 71.8 & 1.4 & 1.95 \\
\hline 14 & 81.2 & 3.4 & 4.18 & 82.2 & 4.3 & 5.23 & 78.2 & 2.7 & 3.46 & 73.4 & 0.2 & 0.27 & 74.05 & 2.25 & 3.04 \\
\hline 15 & 84.0 & 2.8 & 3.33 & 85.4 & 3.2 & 3.75 & 79.8 & 1.6 & 2.01 & & & & & & \\
\hline 16 & 86.3 & 2.7 & 3.14 & 86.7 & 1.3 & 1.50 & & & & & & & & & \\
\hline 17 & 86.3 & 0 & 0 & & & & & & & & & & & & \\
\hline 18 & 87.8 & 1.5 & 1.71 & & & & & & & & & & & & \\
\hline 19 & 88.1 & 0.3 & 0.34 & & & & & & & & & & & & \\
\hline 20 & 89.0 & 0.9 & 1.12 & & & & & & & & & & & & \\
\hline
\end{tabular}


第 10 表坐高 (\%)

\begin{tabular}{|c|c|c|c|c|c|c|c|c|c|c|c|c|c|c|c|}
\hline \multirow{2}{*}{$\begin{array}{l}\text { 年 } \\
\text { 命 }\end{array}$} & \multicolumn{2}{|l|}{$\Rightarrow$} & 世 & \multicolumn{2}{|c|}{ 本 } & & 米 & 國 & & \multicolumn{2}{|c|}{ 比 } & & \multicolumn{2}{|c|}{ 南 } & \multirow{2}{*}{ 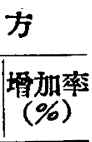 } \\
\hline & $\begin{array}{l}\text { 坐高 } \\
\text { (cm) }\end{array}$ & $\begin{array}{l}\text { 增加 } \\
(\mathrm{cm})\end{array}$ & 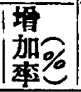 & $\begin{array}{l}\text { 坐高 } \\
(\mathrm{cm})\end{array}$ & $\begin{array}{l}\text { 壻加 } \\
\text { (cm) }\end{array}$ & $\begin{array}{c}\text { 增加率 } \\
(\%)\end{array}$ & $\frac{\text { 坐高 }}{(\mathrm{cm})}$ & $\begin{array}{l}\text { 埧加 } \\
(\mathrm{cm})\end{array}$ & \begin{tabular}{|l} 
堛加本 \\
$(\%)$
\end{tabular} & $\begin{array}{l}\text { 坐高 } \\
(\mathrm{cm})\end{array}$ & $\begin{array}{l}\text { 增加 } \\
\text { (cm) }\end{array}$ & $\begin{array}{c}\text { 塔加率 } \\
(\%)\end{array}$ & $\begin{array}{l}\text { 坐高 } \\
(\mathrm{cm})\end{array}$ & $\begin{array}{l}\text { 增加 } \\
\text { (cm) }\end{array}$ & \\
\hline 6 & 62.3 & 1 & & 63.4 & & & & & & & & & & & \\
\hline 7 & 64.2 & 1.9 & 2.96 & 65.3 & 1.9 & 2.91 & 63.5 & & & & & & 59.85 & & \\
\hline 8 & 65.9 & 1.7 & 2.58 & 67.3 & 2.0 & 2.97 & 65.5 & 2.0 & 3.06 & 63.1 & & & 62.75 & 2.9 & 4.62 \\
\hline 9 & 67.8 & 1.9 & 2.80 & 69.2 & 1.9 & 2.75 & 67,5 & 2.0 & 2.97 & 65.0 & 1.9 & 2.92 & 64.65 & 1.9 & 2.94 \\
\hline 10 & 70.7 & 2.9 & 4.10 & 71.4 & 2.2 & 3.08 & 69.5 & 2.0 & 2.88 & 66.9 & 1.9 & 2.84 & 66.25 & 1.6 & 2.42 \\
\hline 11 & 72.7 & 2.0 & 2.75 & 74.1 & 2.7 & 3.64 & 71.9 & 2.4 & 3.34 & 68.8 & 1.9 & 2.76 & 68.55 & 2.3 & 3.36 \\
\hline 12 & 76.2 & 3.5 & 4.60 & 77.0 & 2.9 & 3.77 & 74.4 & 2.5 & 3.36 & 71.0 & 2.2 & 3.10 & 70.6 & 2.05 & 2.90 \\
\hline 13 & 78.8 & 2.6 & 3.30 & 79.8 & 2.8 & 3.51 & 77.6 & 3.2 & 4.12 & 74,2 & 3.2 & 4.32 & 72.05 & 1.45 & 2.01 \\
\hline 14 & 81.2 & 2.4 & 2.96 & 81.5 & 1.7 & 2.08 & 79.6 & 2.0 & 2.51 & & & & 76.65 & 4.6 & 6.00 \\
\hline 15 & 81.9 & 0.7 & 0.85 & 82.3 & 0.8 & 0.97 & 80.8 & 1.2 & 1.49 & & & & & & \\
\hline 16 & 82.3 & 0.4 & 0.49 & 82.9 & 0.6 & 0.72 & & & & & & & & & \\
\hline 17 & 82.2 & -0.1 & -0.12 & & & & & & & & & & & & \\
\hline 18 & 83.2 & 1.0 & 1.21 & & & & & & $!$ & & & & & & \\
\hline 19 & 81.6 & 1.6 & -1.96 & & & & & & $i$ & & & & & & \\
\hline
\end{tabular}

第 11 表比坐高の比較

\begin{tabular}{|c|c|c|c|c|c|c|c|c|c|c|c|c|c|c|c|c|}
\hline \multicolumn{7}{|c|}{$\delta$} & \multicolumn{6}{|c|}{ 우 } & \multirow{2}{*}{\multicolumn{2}{|c|}{$\begin{array}{c}\text { 来國人 } \\
\text { est }\end{array}$}} & & \\
\hline 年 & & 世 & 本 & 人 & $\begin{array}{c}\text { 米 } \\
\text { Collin }\end{array}$ & 今ark & & 世 & 本 & 或人 & 米 萳 & 人 & & & \multicolumn{2}{|c|}{$\begin{array}{l}\text { 米 } \\
\text { Porter }\end{array}$} \\
\hline 命 & $\begin{array}{l}\text { 坐高 } \\
\text { (cm) }\end{array}$ & 些 & $\begin{array}{l}\text { 坐高 } \\
\text { (cm) }\end{array}$ & $\begin{array}{l}\text { 皆 } \\
\text { 育\% }\end{array}$ & $\begin{array}{l}\text { 坐高 } \\
\text { (cm) }\end{array}$ & $\begin{array}{c}\text { 比坐高 } \\
(\%)\end{array}$ & $\begin{array}{l}\text { 坐高 } \\
(\mathrm{cm})\end{array}$ & 夎\% & $\begin{array}{l}\text { 坐高 } \\
\text { (cm) }\end{array}$ & 毞\% & 坐高 & 坒 & $\begin{array}{c}\text { 比 } 5 \\
\delta\end{array}$ & $\begin{array}{c}\text { 高 } \\
\text { 甲 } \\
\end{array}$ & 比 坐 & $\begin{array}{l}\text { 高 } \\
\text { 웅 }\end{array}$ \\
\hline 6 & & & 64.2 & 57.8 & & & 62.3 & 55.3 & 63.4 & 58.0 & & & 55.2 & 55.7 & 55.5 & 54.7 \\
\hline 7 & 64.9 & 56.1 & 66.2 & 57.1 & 63.8 & 53.8 & 64.2 & 55.3 & 65.3 & 57.4 & 63.3 & 53.5 & 54.7 & 54.6 & 54.3 & 54.2 \\
\hline 8 & 66.2 & 54.7 & 67.9 & 56.4 & 66.0 & 52.7 & 65.9 & 55.8 & 67.3 & 56.9 & 65.5 & 52.6 & 54.0 & 53.9 & 53.8 & 53.3 \\
\hline 9 & 68.4 & 54.5 & 69.2 & 56.0 & 68.0 & 52.2 & 67.8 & 54.5 & 69.2 & 56.4 & 67.5 & 52.1 & 53.6 & 53.5 & 53.7 & 53.2 \\
\hline 10 & 70.6 & 53.8 & 71.8 & 55.6 & 69.8 & 51.7 & 70.7 & 54.0 & 71.4 & 55.8 & 69.5 & 51.7 & 53.5 & 53.4 & $52.8^{7}$ & 52.6 \\
\hline 11 & 72.7 & 53.5 & 73.7 & 55.0 & 71.5 & 51.2 & 72.7 & 53.7 & 74.1 & 55.3 & 71.9 & 51.2 & 52.4 & 52.9 & 52.6 & 52.3 \\
\hline 12 & 74.8 & 53.2 & 76.1 & 54.7 & 73.3 & 50.8 & 76.2 & 53.7 & 77.0 & 55.1 & 74.4 & 50.9 & 52.3 & 52.4 & 51.9 & 51.7 \\
\hline 13 & 77.8 & 52.7 & 77.9 & 54.3 & 75.5 & 50.4 & 78.8 & 53.5 & 79.8 & 55.1 & 77.6 & 51.1 & 51.9 & 52.5 & 51.5 & 52.1 \\
\hline 14 & 81.2 & 52.7 & 82.2 & 54.0 & 78.2 & 50.4 & 81.2 & 54.0 & 81.5 & 55.1 & 79.6 & 51.2 & 51.8 & 52.7 & 51.2 & 52.7 \\
\hline 15 & 84.0 & 52.7 & 85.4 & 54.2 & 79.8 & 50.3 & 81.9 & 54.1 & 82.3 & 55.2 & 80.8 & 51.5 & 51.8 & 53.0 & 51.1 & 53.0 \\
\hline 16 & 86.3 & 52.5 & 86.7 & 54.4 & & & 82.3 & 54.3 & 82.9 & 55.4 & & & 52.0 & 53.3 & 51.9 & 53.3 \\
\hline 17 & 86.3 & 53.2 & & & & & 82.2 & 54.4 & & & & & 52.5 & 53.5 & 51.6 & 53.6 \\
\hline
\end{tabular}

查したものは $53.7 \%$ であつた。児童の発育時 期に於ては平均比下肢長 $54.0 \%$ で本国人の 51.3 \%に比べると $2.7 \%$ 大である。米国人は大転 子を基点としで测つたものであるから直接比 較出來ないが米国人は $53.0 \%$ ある。

\section{第3䇴 坐高}

二世の坐高は 89.9 糎で日本で一定時成育し た二世は少し高く, 90.7 糎で 0.8 粝高くなつて いる。 日本人は 87.2 粝で夫れより 2.7 粝小さ い.87.2 糎は 次の 四氏の 縝計から算出した 
ものである「日置氏(金沢节) $86.2 \pm 0.11$ n506。 鮫島, 加藤両氏 (薩摩) $88.20 \pm 0.25 \mathrm{n} 99$, 同上 (大隈) $88.40 \pm 0.23 \mathrm{n} 74$, 中山（秋田） $87.10 \pm$ $0.30 \mathrm{n} 100$ を其数字に $\mathrm{n}$ を乘したるもの了和 を n の総和にて除し $87.2 \pm 0.09$ を出したもの である了.

須々木博士の児童の坐高を見ると本国人は 二世ょり 1 2 糎禀い。そして二世は米国人よ
ク更に 1〜2 糎高い数字を示している（第 9 , 第 10,11 表，第 2 図).

比坐高を見ると，二世は $54.1 \%$ で日本で一 時大きくなつた者は $55.0 \%$ になつてる。內 地人 $55.3 \%$ であるから $1.2 \%$ 小である（第3.10 表). 日本人との各監幹の比較は後章に詳迅し た.

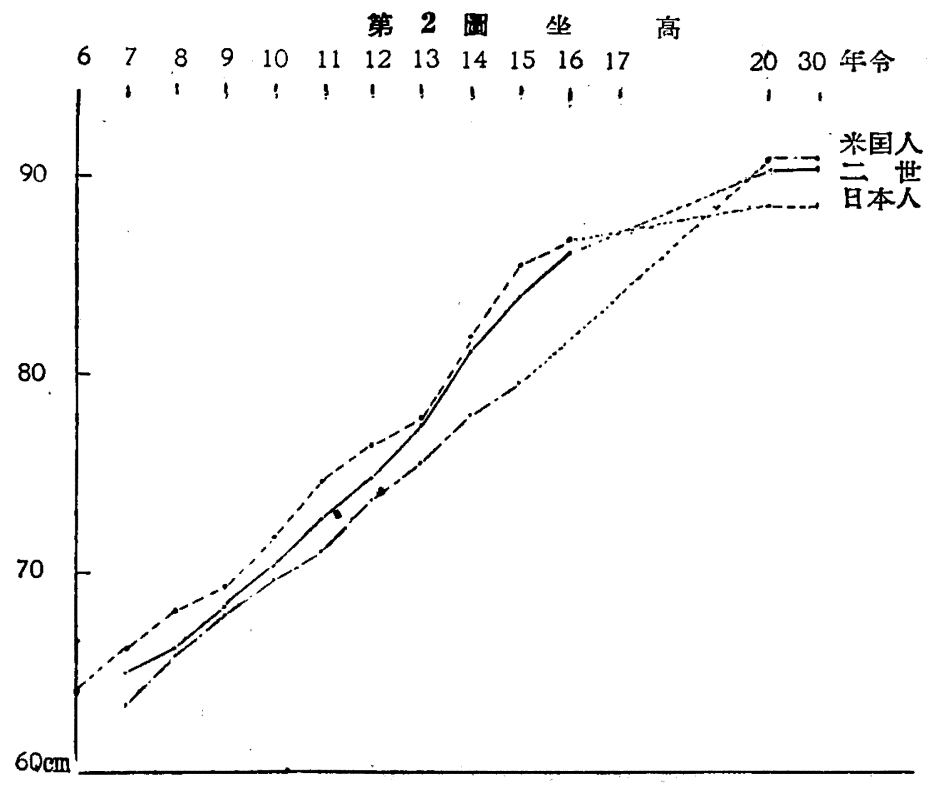

\section{第 4 䇫 体重}

全体の本均体重は 60.7 灹でハワイ及び日本 で成育した人は米国で発育しけ人ょり約 1 䏕 小である。これを內地人の 51.8 䏕に比較すれ ば 8.9 䏕大 $(17.0 \%)$ である. 石原のさきに調 查したもの全平均 60.5 㿞で（ロスアンヂル スのものでは 64.28 狂) あるというに一致し ている． 又児童の体重を見ると內地人に比し て 3 万至 5 䏕 $(13.0 \%)$ 大である. 又其年々の体 重增加率を見ると二性は米人と同し割合に惯 加し，各年令で日本內地人を凌駕していること は表に見る通りである．此等はさきの吉田博 士のハワイ児童の数値とよく一致している。
次に示す上膊囲，ローレルの指数ベリデッ チの指数，皮厚なども皆然食が世の著しく 優れていることを示するのである。

次に二世の父の体重は 61.6䏕で內地の同年 令の体重に比し 4.8 灹大である。，又母の体重 は 53.4 䏕で內地の 46.2 䏕に比し7.2大である。 即ち米国生几二世の身長，体重は內地人に比 し優つているが,其両親の身長体重も偠ていた こととか分る. Shapiro 氏のハワイの日本人二 世 70 余名を調べたものは身長 162,53 粧, 体重 $56.7 \mathrm{~kg}$ である。米国以外に成育した二世の体 重を見るに，玉井氏の比帛育古の二世 211 名 の体重は本国人に比し 7 才〜 14才で男子 2〜5 


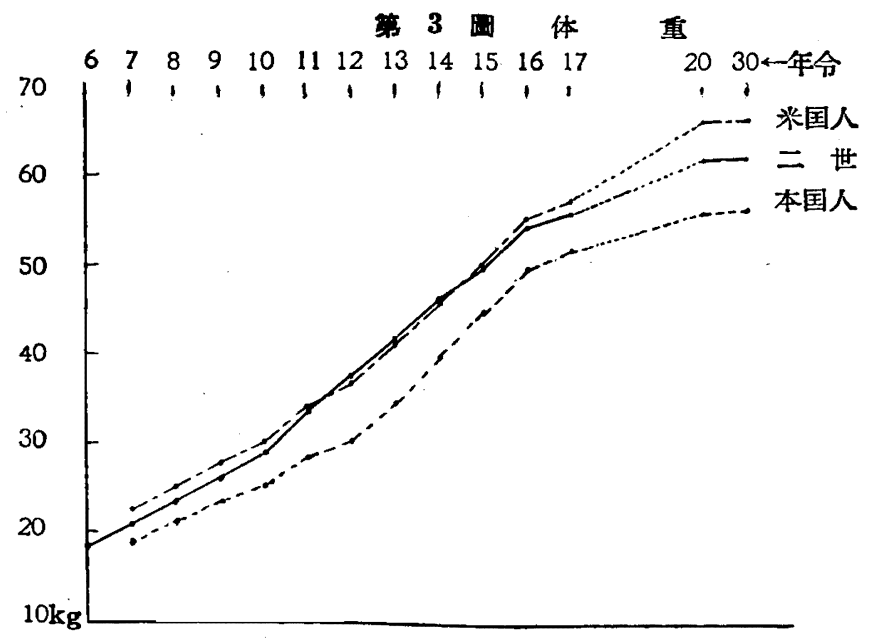

第 12 表見童の体重

\begin{tabular}{|c|c|c|c|c|c|c|c|c|}
\hline & & \multicolumn{3}{|c|}{ 우 } & \\
\hline 年 & $\vec{\rightleftarrows}$ & $\begin{array}{l}\text { 本 } \\
\text { 國 }\end{array}$ & $\begin{array}{l}\text { 米 } \\
\text { 國 } \\
\text { 人 }\end{array}$ & $\overrightarrow{\ddot{世}}$ & $\begin{array}{l}\text { 本 } \\
\text { 國 }\end{array}$ & $\begin{array}{l}\text { 来 } \\
\text { 國 } \\
\text { 人 }\end{array}$ & 比島 & \\
\hline 6 & 19.6 & 17.3 & & 18.8 & 16.7 & & & \\
\hline 7 & 21.4 & 19.1 & 22.3 & 20.7 & 18.5 & 21.7 & 17.5 & \\
\hline 8 & 23.5 & 21.1 & 24.6 & 22.8 & 20.4 & 23.9 & 19.3 & 18. \\
\hline 9 & 25.8 & 23.2 & 27.1 & 25.1 & 22.5 & 26.0 & 21.0 & 20. \\
\hline 10 & 28.6 & 25.4 & 29.9 & 27.9 & 24.9 & 28.7 & 23.0 & 22. \\
\hline 11 & 32.3 & 27.8 & 32.4 & 31.4 & $27 . \dot{8}$ & 31.6 & 25.1 & 24. \\
\hline 12 & 36.2 & 30.3 & 35.4 & 37.1 & 30.3 & 36.2 & 28.3 & 27. \\
\hline 13 & 40.5 & 34.2 & 39.3 & 41.0 & 35.9 & 40.8 & 29.9 & 32. \\
\hline 14 & 45.4 & 39.5 & 44.0 & 43.4 & 37.7 & 45.1 & 32.2 & \\
\hline 15 & 50.2 & 45.0 & 49.4 & 44.8 & 43.3 & 48.6 & & \\
\hline 16 & 53.8 & 48.8 & 55.5 & 45.9 & 44.4 & 51.1 & & \\
\hline 17 & 55.8 & 51.4 & & 46.6 & 46.5 & & & \\
\hline
\end{tabular}

〜7 䏕小であり.女子に於て 2 3.5 䏕小であ る. 米国生れ二世に比較すれば4〜6〜13 灹小 であり，女子で 4 9〜12 舮小である（第 12 表, 第 3 図).

\section{第 5 節 胸圍，上膊園及び皮厚}

二世の胸囲は 86.9 糎で內地の 82.5 糎に比し て 4.4 糎 $(5.4 \%)$ の差で眊童の発育時に於け る数も又內地人に比して 3 粝の偍秀さを示し てるる。従つて比胸囲を見ても二世か５2.41\%
に対して內地の $51.55 \%$ で 0.86\% の優秀さ走 示してるる。二世児童に於ても大体同じであ る.

各国人の此胸囲を見るに，第 13 表に見る如 く独人，英人，アイ邓は大きく，ベルギー人， 佛人は稍々小さく，日本人，朝鮮人は尚小さ い. 支那人はや引大きい。今日本人の比胸囲 をべルギー人に比較すると 14 才迄年々小さく なり夫れから文大きくなること同しである。

二世を見ると，日本人と 11 才迄は大体同し であるが，夫れからは3〜4粝大きい，比胸团 る同じである．英人に比較すれば，各年令で 2〜3 糎小さい。

米国以外の地域に成育した二世の胸囲に就 て見ん，南洋育ち二世を見るに（江口氏），移 民せし日本人は $53.4 \%$ ，南洋育ち二世 $52.3 \%$ で1.1\% だけ小さく．塚田氏の南方育ちにて は 7〜14 才で平均 $0.4 \%$ 位小で 大体南洋育ち は細長型である， 又玉井氏の比島のものは本 国人ょり 7〜14 才で 本均 0.2 粝位大きく，比 胸田も日本人ょり僅加に大きい傾向である。

\section{上膊、囲}

二世は 27.8 粝で 內地人の 24.5 糎に比して 3.3 粝 (13.5\%) の優秀さを示してるる。その 標準偏差から比較して見ても最も大なる差を 


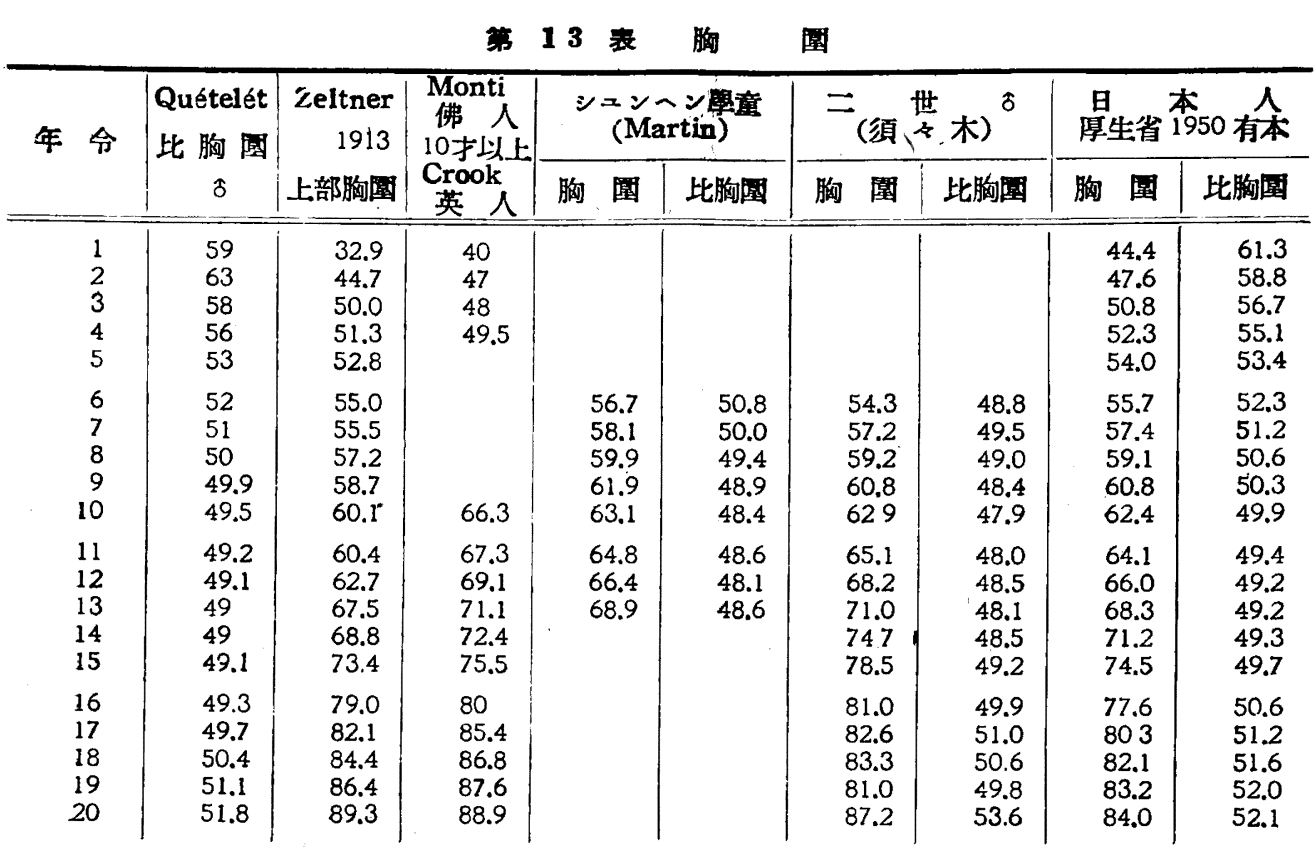

各國人比胸国（合）

\begin{tabular}{|c|c|c|c|c|c|c|c|c|c|c|c|}
\hline 露人 ( & $=\not x+1$ & 49.7 & スワイッ人 & 50.7 & & 毛ー & & 528 & 佛 & & \\
\hline 潖 & 人 & 55.4 & 本 人 & 50.8 & $\gamma$ & 1 & x & 577 & 朝 & 鮮 & 人 \\
\hline 支 那 & 人 & 51.5 & & & & & & & & & \\
\hline
\end{tabular}

示してるる。比上膊囲は二世は16.8であるが， 日本人は 15.3 で 1.5 の著差である。

欧人の上膊团を見るに，Bach 氏は独人（身 長 168.0) 28.5(女 24.8), 比上膊囲 17.0(女15.0) で、コロラドインヂフ人 (Colorado Indianer) 16.1 (女 17.2) である.之れに比し二世は独人 沉同じ位であるが，日本人とは著しい差違を 示すのである．元來上膊囲は各国人間に人種 的差はない，節肉の練習と脂肪膜に体るもの であるからである，反之栄羪の指数として重 要なものである(3裴).

\section{皮厚}

皮厚は本均 15.6 糎で日本で一定期間成育し たものは 14.3 糎で 1.3 劣つてるる。队地の本

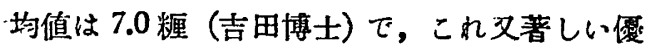
秀さて123\%といふ差を示してるる。これる 办栄餋の差を示すものである。
第 14 表

\begin{tabular}{|c|c|c|}
\hline \multirow{2}{*}{ 各國人名 } & \multicolumn{2}{|c|}{ 各國此上肢 長 } \\
\hline & $\delta$ & $\%$ \\
\hline ノールウ $=$ - 人 & 43.3 & 43.2 \\
\hline 獨 人 & 44.5 & 44.4 \\
\hline バ & 45.1 & 44.7 \\
\hline & 44.7 & \\
\hline$\therefore n \neq-人$ & 45.5 & 44.2 \\
\hline 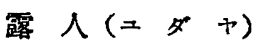 & 45.1 & 44.1 \\
\hline 米 1 & 45.0 & 44.4 \\
\hline ネグロ (Dahome) & 45.6 & \\
\hline 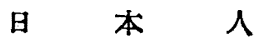 & 43.1 & \\
\hline$>1 \times 1$ & 46.0 & 45.1 \\
\hline 南 支 那 人 & & 44.6 \\
\hline
\end{tabular}

\section{第 6 笁 ローレル示数及びペリデッ チー示数}

ロー゚ルの示数 全体の本均は 134.4 で米 
国で成育した者が最もよく $136.4 て ゙$, 次いで日 本で一定期間成育しだ者か：135.5で，ハワイの ものは劣つて 131.0 であるこれを本邦の本 均塚田氏の 124.9 に比較すると $9.5(7.6 \%)$ 伾 秀である．米国以外の地域に成育した日本人 二世のローラー示数に就て見るに，此島育ち のものは体重が 0.5 灹小なるだけに，示数も 122.0 で 2.9 小となつてるる．塚田氏の南洋に 3 年以上㕕ちしものは，125.0 で殆んど日本人 と差がないが，南洋生れのものは 7 才〜 14 才 の間て 125 135て，日本人本均よりや了劣 る. 又概して身長大なるもの程ローラー示数 は小となるものであるのに，米国生れ二世の 場合は身長大なるもの程口ーラー示数大とな つてるるのを見る。

\section{第 7 節 頭長，頭巾，頭示数に就乙}

頭长は 186.4 籷で 日本全国的に調查した解 剖学会の示した 185.9,坏田博士の示した 187.7 粍と略等しく，東北地方ょり稍々小て，北陸 地方より一層小である。

頭巾は 158.9 䊗で解剖学会の 155.6 粍を初め 日本各地の数より 6〜7 粍位大である。

示数は85.21 で，日本全国に涉る 塚田博士 の80.88, 他の各地方の 81〜77 よ、り大である. 即古二世は頭幅大きく従つて頭示数が大きく なつてるる・後章に論述した。

佾本調查計測に特に援助されし 公衆蕚生院 古屋, 熊沢, 大森博士等に讙謝し, 文部省科 学研究費の補助を仰きしことを謝す。

第 2 編 米國に於けろ二世の研究成績及び本成績との比較

指遒 石 原 房 雄

\section{第 1 節 二世新生兒と日本人新生兒 との比較}

指运 石 原 房 雄

二世新生児に就ては，伊藤氏か: Los Angeles 市て 日本病院內男 94, 女 109 名合計 203 名に 就て研究したものがある. 其母令は 17〜41 才，(大多数は.20〜26才） $55.9 \%$ は初座であ る.これと比較せん為め予は賛育会病院に於 て出生した新生児 33 例（男 15，女 18）につい てマルチン氏の方式により同一項目で同一方 法で計測したのである．計测は目下場所をか 人他の産院でも続行中なので統計学的の計算 は全部終了後に譲り，姟には算術本均のみと 記した。

計測を行つた新生児は正常妊娠で好娠満期 の正規分婏によるるの3 るを選び,体重を除い た他はすへて生後 4 6日目のものについて行
つた．体重は出商直後 2,3 日は減少するのて 直後のものを選んだが，頭部等の計测は出座直 後は変形したものか:多いので 4 日後を選んだ。

二世との比較

1. 身長と体重 二世は冈地日本人より相当 俖秀で，身長を見ても，米人には及ばないが， 佛人，簬人の新生児を淩ぐものであること表 の通りである (15 表)。即ち二世は身長 $2.0 \mathrm{~cm}$, 体重 $300 \mathrm{~g}$ 內地の人上り大きく，米人に较ぶ れば身長 $0.7 \mathrm{~cm}$ (男女本均) ・体重 $190 \mathrm{~g}$ 小 さい.

各國新生兒身長

\begin{tabular}{ll|l|l}
\hline & & $\delta$ & \multicolumn{1}{c}{ \% } \\
\hline 英 & 人 & 49.6 & 49.1 \\
露 & 人 & 49.5 & 48.3 \\
佛 & 人 & 49.9 & 49.2 \\
㺈 & 人 & 51.2 & 50.3
\end{tabular}




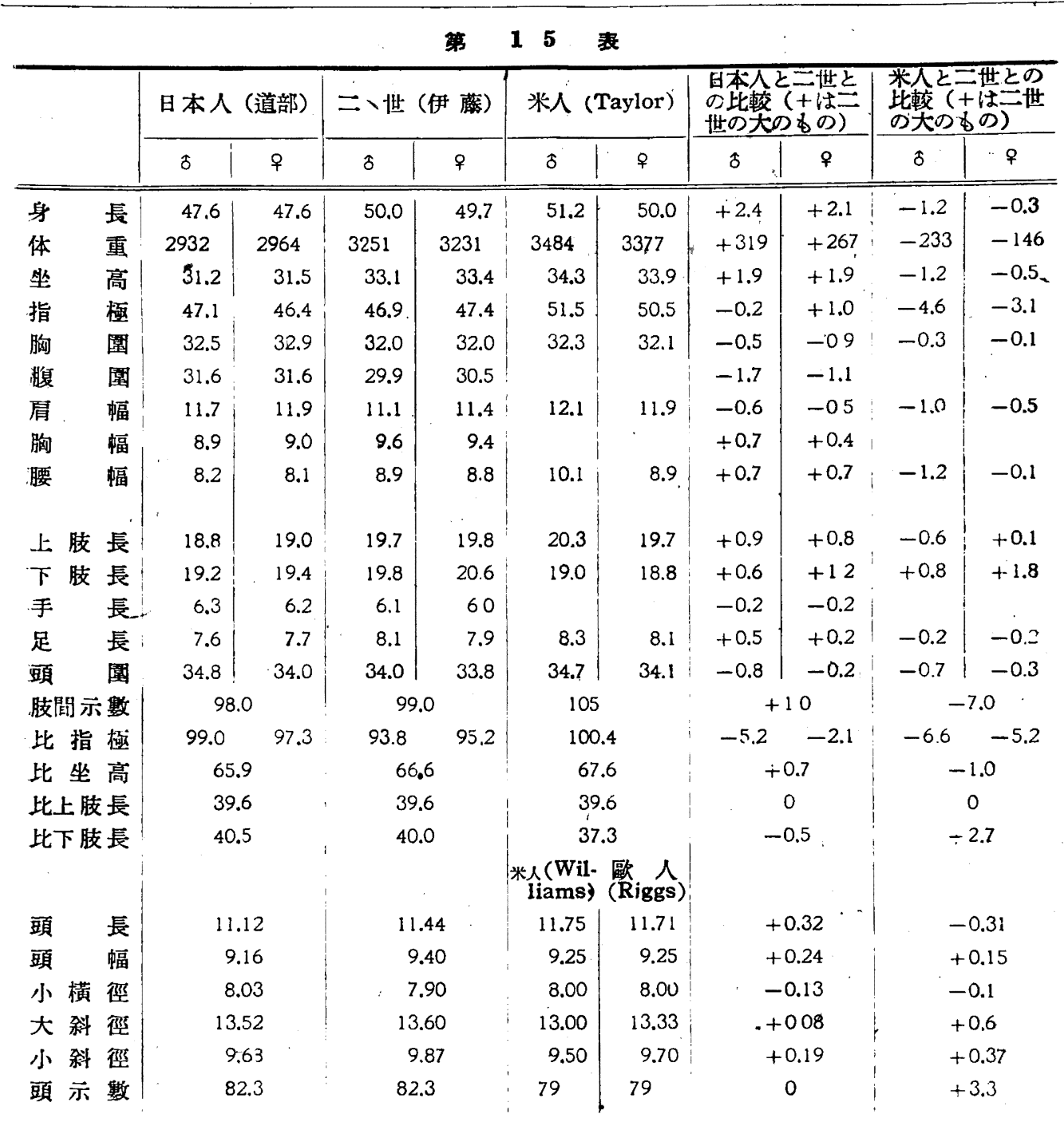

2. 上肢長下肢長共に二世は長くなり肢間示 数は 1 大きい・不肢長が短くなつた為めであ る. 比下肢長は二世か～ 0.5 小さくなつてるる。 比上肢長は差はない，手は短く，足は長くな つている。

3. 坐高, 比坐高共に二世の方が高くなつ るる，指極は実数て男子 0.2 娍り女子 1.0 增加 していて, 比指極も男子 5.2 減り女子 2.1 減ち ている。肩幅, 胸囲; 腹囲は二世位はやや小さ くなつてるるか，胸幅，腰幅はやろ大きくな

\section{ロてるる・}

4. 頭部の計值では頭長, 頭幅, 大斜径共に 二世は大きい，小横径のみやろ小さい，頭示 数は全く等しい，二世の成人では頭示数方， 日本人より 5 も大きくなつてるるか，新生児 では同じである。

次に米白人と比較して見ん，総して二些の 方が小さいが，特に注目されるものが 4 ある。

1. 頭示数は各年令の推移に於て常に 3 位白 人は日本人ょり低いが，新生児に於ても同し 
割合で低い，頭長は $3 \mathrm{~mm}$ 大きくなり，頭幅 も日本人ょりも $2 \mathrm{~mm}$ 大きく白人ょりも太き い. 大小科径を大きい(第 1 輯 9 図参照).

2. 指極 米人は指極が身長より長くなつて いる. 二世や日本人は逆に指極か沸長より短 い. Taylor の計測でも比指極が 100.4 である が日本人は 98 になつている. 三世は 94.5 で 倘小さくなつている(第 15 管 115 頁第 8 図).

3. 下肢長，米人の新生児ては，二世ょり も，又日本人ょりる下肢長が短くなつてるる。 (之れは 大転子から同一の方法で計測したも の).そして見ると, 成人では米人はひどく日 本人より下肢長が長いのであるか， 新生坚で は逆に日本人或は二世の下肢長より「男 $0.8 \mathrm{~cm}$ $($ ( $1.8 \mathrm{~cm})$ 了短いのを見るのである. 又比下 肢長も $2.7 \%$ を小さい。

4, 上肢長 白人は上肢長か下肢長より長い 加，日本人は逆に下肢長の方が長い。故に
白人の肢間示数は（Taylor 氏）105で日本人 の 98 ょり 7大くなつてるる。佛人 Godin 氏の計測でも 100 となつてる，Weissenberg 氏の南露人の計测でも上肢長の方が長く 104 となつてるる。日本人保新生児では下肢長が 特に長く，肢間示数は小さいのである。しか し二壮は日本人ょり大きく白人に近つき 99 に なつている(第 15 表) (第 15 癹 114 頁第 7 図). 二世は上䁌長が長くなり下䁌長割合に短く 肢間示数大きくなり坐高，腰幅の大きくなつ ているが発育後は皆小さくなつてるるものて ある.台実驗数を增し研究中である。

\section{第 2 節 伊藤氏の女子成人の成績に 就て 飯 高 歲子}

伊藤氏の成人女子の研究は 267 名で其第 1 群は.135 名で米国に傆れて，そこで成育した人 で, 其年令は 18 求 30 才（本均 23 才），単身

第 16 表 伊藤氏女子成績と日本人との比較

\begin{tabular}{|c|c|c|c|c|c|c|c|c|c|c|}
\hline & & $=$ & No. & 135 & 翺 米 & 二世 $\mathrm{N}$ & o. 125 & （星內本 & 仝) & 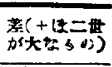 \\
\hline 身 & 長 & 154.00 & \pm 2.40 & $\sigma 50.00$ & 151.93 & \pm 2.20 & $\sigma 54.90$ & 149.2 & & +4.8 \\
\hline 坐 & 高 & 84.88 & \pm 1.51 & $\sigma 26.16$ & -83.96 & \pm 1.74 & $\sigma 28.90$ & $\begin{array}{l}82.9 \\
82.94 \text { (鈴木) }\end{array}$ & \pm 1.35 & +2.0 \\
\hline 比 坐 & 高 & 55.12 & \pm 0.089 & $\sigma \quad 1.10$ & 55.30 & \pm 0.115 & $\begin{array}{ll}\sigma & 1.25\end{array}$ & $\begin{array}{l}55.4 \\
55.34 \text { (鈴木) }\end{array}$ & \pm 0.09 & -0.3 \\
\hline 体 & 重 & 50.51 & & & 50.90 & & & 47.6 & \pm 0.09 & +2.9 \\
\hline 比 & 重 & 138.0 & & & 145.7 & & & & & \\
\hline 下 肢 & 長 & 77.88 & \pm 2.16 & $\sigma 37.35$ & 76.74 & \pm 2.60 & $\sigma 43.75$ & $75.27 \quad$ ("I) & \pm 1.60 & +2.61 \\
\hline 比下肢 & 長 & 50.58 & \pm 0.14 & & 50.52 & \pm 017 & & 50.28 (鈴木) & \pm 1.10 & +0.3 \\
\hline 指 & 極 & 153.14 & \pm 3.24 & $\sigma 55.9$ & 151.30 & \pm 3.62 & $\sigma 60.15$ & 148.0 & & +5.1 \\
\hline 比 指 & 極 & 99.44 & \pm 0.21 & & 99.59 & \pm 0.238 & & 99.2 & & +0.24 \\
\hline 肩 & 幅 & 35.21 & \pm 0.83 & & 34.92 & \pm 0.90 & & 33.7 & & +1.5 \\
\hline 比 & 幅 & 22.87 & \pm 0.05 & & 23.00 & \pm 0.059 & & 22.5 & & +0.3 \\
\hline 腰 & 幅 & 28.26 & \pm 0.79 & & 28.43 & \pm 1.02 & & 26.9 & & +1.3 \\
\hline 比 腰 & 幅 & 18.35 & \pm 0.05 & & 18.72 & \pm 0.067 & & 18.0 & & +0.35 \\
\hline 頭 & 園 & 54.24 . & \pm 0.84 & ๑ 14.46 & 5,385 & \pm 079 & $\sigma 13.10$ & $\begin{array}{l}54.37 \text { (中山) } \\
54.20 \text { (鉿木) }\end{array}$ & \pm 065 & +0.04 \\
\hline 比 頭 & 園 & 35.22 & \pm 0055 & & 35.46 & \pm 0.052 & & 36.6 & & \\
\hline 胸 & 畧 & 75.20 & \pm 2.79 & & 77.67 & \pm 3.47 & & $\begin{array}{l}78.8 \\
-81.45 \text { (鈴木) }\end{array}$ & \pm 2.94 & -62 \\
\hline 比 胸 & 園 & 48.84 & \pm 0.18 & . & 50.88 & \pm 0.23 & & $\begin{array}{l}52.8 \\
54.40 \text { (鈴木) }\end{array}$ & \pm 0.196 & -5.6 \\
\hline
\end{tabular}


者 61 名，結婚者 74 名，高等女学校出身 109 名でカルホル二ア生れ 102 名，ワシントン州 生れ 13 名である (16 表).

次で第 2 群は 125 名で米国に生れ 6 タ月乃 至 9 才迄の間 (平均 3 才 8 ケ月) 日本に帰り 発育したもので（平均日本滞在期間は 4 年 2 ク月）ある. 其 103 名はカルホルニフ生れて ある.

少同時に三楽病院で 鈴木氏か;同氏の 委啒に より特に同一方法によつて 150 名の看護婦の 体格調查をしたるのであるが夫れは職業的に 一定し且人数も少いので女子䅺準としては竹 內氏のものを表示し比較した． 只計測法が違 つてるるるの即ち下肢長及び 数値著差のある 胸围とは鈴木氏のものを併せ表示した。

今其成績を見ると,身長に就て二世は日本人 女子に比し 4.8 糎大で，一定時日本で発育した ものは稍々小さいがそれで 2.7 粝大である。

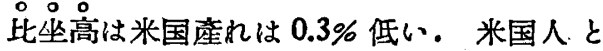
比較すると米ネグロは坐高は最も低い，米国 人，インデフン婦人 (北太平洋岸)はいくらか 高いか日本人は最す高い(17 表 A)。

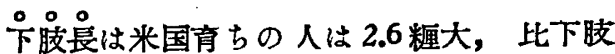
長は $0.3 \%$ 大である。換言すれば比坐高 $0.3 \%$ 減りそれだけ比下肢長が伸びていた。後に詳 述する. 之の数字は大転子から測定したもの であるから直接竹內氏其他の棘状上端からの 数字に比較出來ない，故に鈴木氏の数值を表 示した。（竹內氏は身長 3 糎伸びるにつれ下肢 長は 1.5 糎（0.9 2.6 糎）伸び其比下肢長は不 変であると日つだ。、ルチン氏は身長の伸びる につれ比下肢長も変ると日つたのであるが,离 では身長の伸びるにつれ変化するのを見た.)

指極 二世阢 $5.1 \mathrm{~cm}$ 大きくなり比指極 99.2 で二世は $0.2 \%$ 大きい，米白人はこれより稍 々大であり,米ネグ口は最る大である。

肩幅は日本女子に比し米国圱れは $35.2 \mathrm{~cm}$ で 1.5 粧も大きいことを証明した。しかし米白 人の大学生の肩幅よりすつと小さい(Bowles. College 㞛幅 $36.89 \pm 1.0$, 身長 164.53).

䫓囲は日本人と同しである。米人に比較す れば頭囲は少し大きい。

胸聿は日本人は $81.5 \mathrm{~cm}$ で二世は $75.2 \mathrm{~cm}$

第 17 表 (A)

\begin{tabular}{|c|c|c|c|c|}
\hline 웅 & 坐 高 & 比坐高 & 長 & \\
\hline 米白人 & $86.84 \pm 2.00$ & 53.28 & 162.8 & Steggrda (Smith college) 1929 \\
\hline 米ネグロ & 77.9 & 51.7 & 157.9 & Hrdlička (Maids) 1928 \\
\hline 米インヂ & $85.8 \pm 1.3$ & 54.8 & 156.7 & Boas (Ceutral Oregon) 1891 \\
\hline 米白人 & 84.4 & 52.2 & 161.69 & Jackson (Minn, Women) 1929 \\
\hline 日本人 & 82.9 & 55.4 & 149.2 & 竹 \\
\hline
\end{tabular}

第 17 表 (B)

\begin{tabular}{|c|c|c|c|c|c|}
\hline 우 & No. & 体 & Rohrer & 身 長 & \\
\hline ミネソタ大學生 & 1022 & $54.37 \pm 0.17$ & 128.6 & 161.69 & Jackson 1929 \\
\hline 全 職 業 & 1075 & 56.20 & 131.2 & 162.39 & Hooton E.H. 1931 \\
\hline 婦人勞務者 & 100 & $61.48 \pm 0.49$ & 145.8 & 161.55 & Bayer. Gray 1934 \\
\hline 二 $\quad$ 世 & 267 & $50.7 \pm 0.41$ & 138.6 & 154.0 & 伊＜wide>藤 \\
\hline 日 本人 & 3856 & $47.6 \pm 0.09$ & 143.4 & 149.2 & 內 \\
\hline
\end{tabular}


で明らかに小さい：之は日本人の乳房が大き いだあである。ニ世の乳房は，一世ょり小て ある。米婦人は 85.88 (士3.66) で比胸囲は 53.15 である。

体告は二世仗日本婦人ょり 2.9 銵 $(5.8 \%)$ 大 であるが，しかし米婦人同年同身長に此較す れば小である。斯くして二世の方が小さいも のは比坐高と胸囲である（第 16,17 表 A, B）.

\section{第 3 節 シャパイロ一氏の成績と本成} 謈との比較及び移民による影祭

飯高歲子

シャバイロー氏の成續と私のものとを比較 してみることる興味あることである。

シャバイロー氏は 1939 年 Oxford大学より ハワイに渡り，日本人移住民 53 名（內ㅇ 18 名), 二世 77 名 (ㅇ 24 名) 計测し, 日本人と しては 日本人の平均を用ひないでハワイ二世
の出身者の多い広島，山口地方の人を自ら日 本に來て計测したもので，それと比較した個 人差がいこと，同時代であること等は皆比 較すべき対照として最適なるのである（18 表). (同大学紀要)

身長は 移民及び內地人に比し二世は 5.3 糎 或は 4.8 糎大きい，しかし $\mathrm{S}$ 氏のは本成績よ りは3.6小さくなつてるる。体重は二世の方 が遙かに县つてるることは同しで栄食が優つ てるるからである。

此坐高は共に低くなつてるることは同して あるが私の成績の方か;著しい。

下肢長はシャバイロー氏は大転子を基点と してるる，が二せと差は 3.5 糎で，私の成 績のものは 3.8 糎で，大体等しい，比下肢長 は共に大きくなつているが，S 氏のは2\%大 きくなり，私の成樍では $0.4 \%$ 大きい許りで ある (18 表).

第 18 表 Shapiro 氏ヘワイ二世の成樍と飯高のものとの比較 (+は二世の方が大きいすの)

\begin{tabular}{|c|c|c|c|c|c|c|c|c|}
\hline & & & \multicolumn{4}{|c|}{ Shapiro } & \multicolumn{2}{|r|}{ 高 } \\
\hline & & & れのさ憵 & 日本島島) & $\begin{array}{l}\text { ヘワイ移民 } \\
\text { せし日本人 }\end{array}$ & 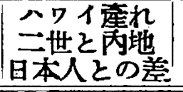 & ヘワイ二世 & $\begin{array}{l}\text { 內地日本 } \\
\text { 人に差 }\end{array}$ \\
\hline 身 & & 長 & 162.53 & 157.22 & 157.79 & +5.31 & 166.1 & +6.0 \\
\hline 体 & & 重 & 56.7 & 53.2 & 55.0 & +3.5 & 59.7 & +7.9 \\
\hline 坐 & & 高 & 85.58 & 83.46 & 82.74 & +2.12 & 89.9 & +1.4 \\
\hline 比 & 坐 & 高 & 52.47 & 53.21 & 52.28 & -0.74 & 54.0 & -1.3 \\
\hline 下 & 肢 & 長 & 77.06 & 73.4 & 75.06 & +3.54 & 86.0 & +3.8 \\
\hline 比 & 下 肢 & 長 & 48.8 & 46.8 & 47.6 & +2.0 & 51.8 & +0.4 \\
\hline 上 & 肢 & 長 & 54.83 & 52.5 & 52.8 & +2.33 & 71.5 & +1.8 \\
\hline 比 & 上 肢 & 長 & 34.1 & 33.4 & 33.4 & +0.7 & 43.2 & -0.4 \\
\hline 肢 & 間 指 & 數 & 70.9 & 71.6 & 70.0 & -0.7 & 83.2 & -1.6 \\
\hline 頙 & 骨 & 愊 & 142.20 & 141.39 & 141.96 & +0.81 & & \\
\hline 頝 & & 高 & 119.87 & 120.83 & 123.74 & -0.96 & & \\
\hline 顏 & 指 & 数 & 84.40 & 85.24 & 87.13 & -0.84 & & \\
\hline 頭 & & 長 & 186.18 & 189.02 & 189.86 & -2.84 & 18.4 & -0.4 \\
\hline 頭 & & 幅 & 155.82 & 151.66 & 151.54 & +4.16 & 15.9 & +8.0 \\
\hline 頭 & 指 & 数 & 83.84 & 80.40 & 81.00 & +3.44 & 86.4 & +5.6 \\
\hline 賁 & & 高 & 49.84 & 48.7 & 50.46 & +1.14 & . & \\
\hline 㫷 & & 幅 & 33.74 & 35.28 & 34.96 & -1.54 & & \\
\hline 畺 & 指 & 數 & 65.38 & 69.92 & 70.48 & -4.54 & & \\
\hline
\end{tabular}


比上肢長は $\mathrm{S}$ 氏のは手部を除いてあるのて 数字が違ふ.其の為めであるのか， $\mathrm{S}$ 氏のは 十で $0.7 \%$ 上肢長は長くなつてる，私の試驗 ではーで $0.4 \%$ 短くなつてるる。䁌問示数は 両方共に一で小さくなつている。
頭部の数字仙良く一致して, 頭長は減り, 頭幅は鏆し, 示数は $\mathrm{S}$ 氏のは 3.4, 私のは 5.6. 增してるる. 顏高及び示数, 鼻示数に就ては 4 節に詳述した。二世は両者共に減少したの を見る。

\section{第 3 編 米國生れ二世の体位と日本人との比暧}

（併に南方，樺太，満洲生れ二世との比較）

\section{石 原 房 雄}

\section{第 1 節 身畏に就て}

娃に從來の二世に関する研究を一括して日 本人のそれと比較して見たい，先つ伊藤氏の 新生児二世の身長に就て，次で吉田氏及び須 々木氏の学童の発育曲線に就て, 次て石原及 び Shapiro 氏，及び飯高の男子成人に就き， 石原, 伊藤氏の女子成人に就ての研究と件 せ，夫れに內地人に就ては本邦啪家研究と比 較して見たい。

第 18 表 B. 二世の身長 $\mathrm{cm}$

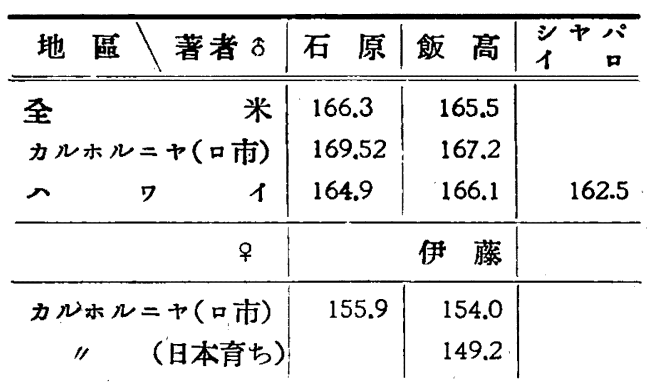

新㒸览の身長は第 15 表に示方が如く，二世 は男子 $50.0 \mathrm{~cm}$ ，女子 $49.7 \mathrm{~cm}$ で日本人ょり $2.4 \mathrm{~cm}(4.8 \%)$ 大きく, 英，露，佛人新生児 より $0.4 \mathrm{~cm}$ 碓り，独米人に比し $1.2 \mathrm{~cm}$ 少る といふ数字を示してるる.

身長の発充 須々木博士の6才から17才ま での発育曲腺を本国人に比較して見ると，日 本人に比し各年令に於て 常に 4 7 粝位（5.3
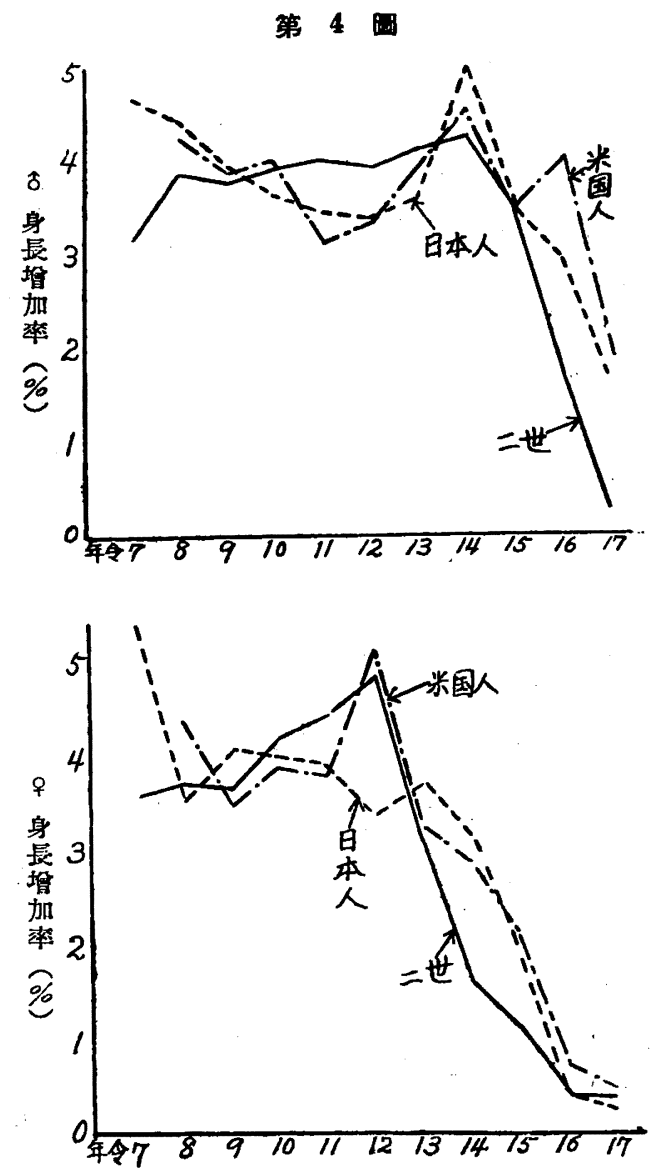

\%）大きい。これは吉田博士の布哇の二世 学童の成績に於て身長は 各年令 $3: 6 \%$ 優秀で あるといふ成績に略々一致する。今其の年々 
の発育曲線を四示すると第1図に示すやうに 米国人と欧州人平均登育珀線と二世との三者 は憼く程相一致してるる。〔しかし桐崎氏の二 世の成樍は身長・体重の曲線が共に日本人と 米人との中間を走るやうになつている。原著 を得られなかつた.)

斯く一致する数字仙 6 才゙から 15 才迄で 15 才以上になると，米国人は份年々作びるが， 日本人は趣を異にして殆んど伸びない，即ち 欧米人は 15 才以後 5 ヶ年に 12.8 粝伸びるが, 日本人では 7.3 糎しか伸びないといふ特長は

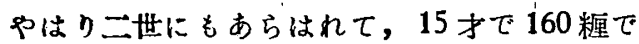
ある方のか，成育して須々木博士の口市の二 世の平均 169.5 緾と比較すると 9.5 糎伸びた事 になつて队地の数字より大きいが白人ょり著 しく少ないことは同じである。

成人゚の身長に就ては，石原の口市のもの最 も高く $169.5 \mathrm{~cm}$ で, 飯高のカルホルニヤ州の もの次で $167.2 \mathrm{~cm}$ である. 共にカルホルニ 十か最る発育に適してるるの証明する。八 ワイは鲎もあり生活も純米国式でないが，飯 高の $166.1 \mathrm{~cm}$ 最高で, 以前の石原の $164.9 \mathrm{~cm}$ これに次ぎ，シャバイロ氏の成績最も惡く $162.5 \mathrm{~cm}$ である。年代による美で，ハワイ二世 る追く伸びてるるるのと思はれる(18表 B)。 次に女子に就て之れを見るに新并览に於て 己に日本人ょり $2.1 \mathrm{~cm}$ 大きく男子の差 $2.4 \mathrm{~cm}$ とほう等しい，須々木博士の6才以上 17 才ま での発充曲線を見るに日本人に比し常に 4 5 䊓大で5\%以上の差を示し男子より其差が大 きい，成人女子の身長克見るに石原が先年 55 名の本均は 155.9 糎で伊藤氏の 135 名の研究 にては 154.0 糎，共に日本人の 149.2 に比し $6.7 \sim 4.8$ 糎 $(4.5 \%)$ 大である.

及二世其発充曲線を見るに米人の夫れと 13 才までは相一致してるるが，夫れから後は 二世は年々の伸び方著しく減少すること內地 日本人と同じである。13才で 147.4 で成人の 155.9 粝迄に8.5糎伸びてるるか，米国人は
163.8 糎（Wilder 氏）に伸びて乃るので其差 16,4糎伸びてるる理である。目本人は 8.5 糎 しか伸びないのと大きな差である， 又內地女 子でも 13 才゙の身長 142,0 と成人との琴 $7.2 \mathrm{~cm}$ で, 二世の 8.5 ょり小さいが，この関係男 子と同しである. 特筆しなければならぬ事て ある。

份年々゚登充亳を詳細に見ると妘に大に異 なる点がある。即ち之れる詳細に見る為めに 身長增加率の曲線を見るに，男子二世は 8 才 加ら 14 才迄で常に $4 \%$ の增加を以て伸び 14 才になつて著しく突出した山孝示してるるが， 日本人は增加率少なく $3.5 \%$ 內外の增加を見 るに止まる。るして14打て突出した山を示す ことは二世も同しである，又欧米人も $3.8 \%$ 位で発育し14牛で山を示すことは同じであ る.佾よく見ると8才から 14 才までは二世は 異常に発育してるることを示す。にの代り 14 才での山の高さは一番低いのである(4図).

女子に於ては特に注意すべ事がある. 8 才から 12 才まで二世は $4 \%$ の增加を示して， 欧米人と同しか, 或は少し優つた率を示し, 12 才で突出した $5 \%$ の山を示すこと, 欧米人 も同じである。然るに日本人だけは 8 才から 11 才まで4\%で增すことは同しであるが，12 才で山を作る代りに $3.4 \%$ の谷を作つてるる

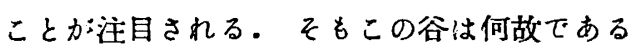
か，或は栄食学的に何か欠陷があるのではな からうか，考へなければならない問題である (第 1,4 図 4, 5 表).

裹きに石原，佐藤の日華混血児に於て 13 才 万至 15 才では日本人ょり $9 \mathrm{~cm}$ も身長が高く なつてるた，成人の時の身長は解らないか， 発育時期に著しい差があるのか，これも食生 活が違ふためではなからうか。

次に米国に非らさる他国に移住し，そこて 成育した人の数值と比較して見ん. 即ちフイ リッビンに於て生れ自発育した二世に就て玉 
井氏のもの注比島に成育した男女 211 名の 7 〜24 才のもので昭利 12 年〜18 年に調查した もので5分の 1 は沖繩出身である。沖繩汹日 本では最も身長の短い地域である（偷年令は 文部省流に記算してあるので牛才のつれを换 算した，以下他の調查表も皆欧州の討算法に 換算した)，成績を第 4，5 表に見る如く米国生 れ二世は比島の夫れに比し， 7,8 才に於ては 7 粝程大であるか： 13 才では 10.0 糎大である. 又比島產れ二世の身長を 冈地日本人に比較し て見ると糎 4 位小である.女子に於ては $3 \mathrm{~cm}$ 位小である。

又塚田氏の”調查したもので內地に生れて南 洋清島に発育満 3 年以上のものを昭和 10１7 年の間に南洋マタラニウム, シナバール, 水 踓島等の国民学校に 委啒し文部省の 身体検查 規定票にょり菟集したものである。其棇数 246 名である內牛数が沖繩県人である．沖繩 以外では東京, 鹿児島, 福島等が多い，今其 の成績と比較して見ると表に見る如く比島育 ちょり $2 \mathrm{~cm}$ 程小であり，日本內地人に比し $6 \mathrm{~cm}$ 位小であり，米国生れ二世に比較すると $10 \sim 17 \mathrm{~cm}$ 小さい，満洲，樺太各地に発有した ものよりを最も小さい数字を示している，又 中沢氏は樺太から引揚げた 6 才以上 59 才迄 の 6.651 名の中から樺太に移佳以來 10 ヶ年以 上経過したものについて調查した，母国は北 海道, 東北の短身の地域の人で，主に漁策， 炭坑夫が多い：これと日本內地人とを比較す ると 6〜17 才で 3〜13cm 小であるが，南方 及び比島発育のものより大となつている．勿 論米国生れ二世より少つて 9～14cm 小であ る。中楯氏の淽洲育ちの児童の調查をも表示 した，南洋育らの児童より稍々優れるという 程度である。

上述の各地域に成育した所謂二壮の 体格を 比較して見るに米国產れは他の地域を拔いて 優秀であるが, 他の比島, 南方誚島, 満洲, 台湾, 樺太等は著しい茫を認めないか此等の
內では最も卧いのは満洲である。満洲は本国 人と稍々劣るとも殆んど差なく，身長の最も 差のあるものでも $2 \mathrm{~cm}$ である。次でフイリ ッピンが良い，日本人ょり $2 \sim 3 \mathrm{~cm}$ 位劣つて いる.次で㩰太の次に台湾育ちのもので $4 \mathrm{~cm}$ 位小である. 最も劣つているのか南方諸島に 育つたものである (4, 5 表).

\section{第 2 節 下肢長，上肢長，坐高の比例 に就て}

下肢長の全本均は 86.3 糎で日本で一定期間 成育し帰米した人はやろ小さく 85,9 糎となつ

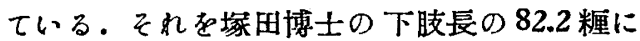
比較すると 4.1 糎大である.身長の差 5.4 糎の 內 4.1 糎即ち $80 \%$ は下肢長の長さによるもの

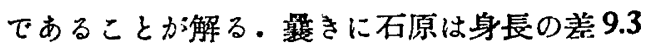
糎あつたもの了下肢長の差 8.3 糎即ち $89 \%$ で あつたというのと類似である。須々木氏の児 童調查では身長の美 6 糎であり，下肢長の差 ช 6.1 粧で $100 \%$ は下肢長の伸びているのに 埽因していた。

二世の比下肢長を見ても，52.1\%で內地日 本人の $51.4 \%$ に比し $0.7 \%$ 大であり，石原の ロスアンヂル ス市民 104 名の 平均は 53.7\% で $2.3 \%$ の差である・須々木博士のロスフンデル ス市児童の本均比下肢長 $54 \%$ に比し，本国児 童の $51.3 \%$ は正に其差 $2.7 \%$ で，成人に於て 示した差と同比率を示したのである。米国児 童の比下䁌長は 53\%となつているか，これは 大転子を基点として計つたもので直接比較さ れない(20表).

第 19 表 二世身長 158 162cm の人の 坐高及下肢長, 上肢長

\begin{tabular}{lr|r|r|r|r}
\hline & $\mathrm{n}$ & $\mathbf{M} \pm \mathrm{m}$ & $\sigma \pm \mathrm{m} \sigma$ & $\mathrm{V} \pm \mathrm{mV}$ \\
\hline \hline 身 & 長 & 47 & $160.0 \pm 0.17$ & $1.16 \pm 0.12$ & $0.73 \pm 0.08$ \\
坐 & 高 & 47 & $87.4 \pm 0.30$ & $2.02 \pm 0.21$ & $2.31 \pm 0.24$ \\
下 肢 長 & 47 & $83.1 \pm 0.25$ & $1.68 \pm 0.17$ & $2.02 \pm 0.21$ \\
上 肢 長 & 46 & $68.7 \pm 0.28$ & $1.89 \pm 0.20$ & $2.75 \pm 0.29$ \\
比上肢長 & 46 & $42.95 \pm 0.16$ & $1.06 \pm 0.11$ & $2.47 \pm 0.26$
\end{tabular}


身長 $160 \mathrm{~cm}$ の二世と日本人との此較

\begin{tabular}{|c|c|c|c|}
\hline & 二 世 & $\begin{array}{l}\text { 日本人之の比 } \\
\text { 較 (王并王) }\end{array}$ & 差 \\
\hline 身 長 & $160.0 \pm 0.17$ & $160.1 \pm 0.10$ & -0.1 \\
\hline 坐 高 & $87.4 \pm 0.30$ & $88.5 \pm 0.06$ & -11 \\
\hline 比坐高 & 54.66 & $55.3 \pm 0.02$ & -0.7 \\
\hline 上肢長 & $68.66 \pm 9 \times 28$ & $69.74 \pm 0.06$ & -1.0 \\
\hline 此上肢長 & $42.95 \pm 0$ & $43.56 \pm 0.03$ & -0.6 \\
\hline 下肢長 & $83.1 \pm 0.28$ & $82.2 \pm 0.07$ & +0.9 \\
\hline 比下肢長 & 52.02 & $51.4 \pm 003$ & +0.6 \\
\hline 肢間示數 & $82.7 \pm 0.14$ & $84.8 \pm 0.06$ & -2.1 \\
\hline
\end{tabular}

各著者による二世の下肢長と日本人との差

\begin{tabular}{|c|c|c|c|c|}
\hline 著 & 者 & $\begin{array}{l}\text { 三世忤の } \\
\text { 下肢長 }\end{array}$ & $\begin{array}{l}\text { 日本人 } \\
\text { との差 }\end{array}$ & 比下肢長 \\
\hline 石 & 原 & $91.0 \mathrm{~cm}$ & $8.3 \mathrm{~cm}$ & $53.7 \%$ \\
\hline 須 & 木 & （幼年者） & 6.1 & 54.0 \\
\hline 飯 & 高 & 86.3 & 4.1 & 52.1 \\
\hline 符高 & 日本人と同 & 83.1 & 0.9 & 52.02 \\
\hline Shap & & $77.1 \times$ & 3.5 & 48.8 \\
\hline 伊 & 藤（㝏) & $77.9 x$ & 2.7 & 50.5 \\
\hline
\end{tabular}

×の二者は大轉子より測定せしすの
佁二世で日本人と略同一只身長を有するもの の下肢長を調へて見た。即ち身長 158〜162 粝 の人 47 名あつたか，其本均下肢長 は 83,1 粝 で內地人の 82.2 粕に比し 0.9 糎大であつた。 比下肢長を見ても52.02\%で內地人の $51.4 \%$ に比し $0.62 \%$ の差がある(19表).

次に女文の午肢長を見るに伊藤氏の調查に よると，二世は 77.9 糎で，一定期間日本で発 育した人は 76,7, 同時に日本內地に於て 婦人 を計つたものは 75.2 糲となつている，共に大 転子基点としたものであるから日本冈地の 数字と直接比较出來ないし加し之れで見る と日本で一定時発育した人は下肢長稍々短く， 日本內地婦人ょり 2.7 糎長くなつている.儿氻 し之れは東京市內で看護婦の計測で，婦人の 內で㹥一番長い下肢長を示すものである（竹 內氏の数字をかりても，女教員比下肢長 50.5 \%で看護婦は $52.0 \%$ である).

故に差は 少ないか; 向其差 2.7 糎は身長の差 4.8 糎の $56 \%$ で男子の示した数字より 小さい

第 20 表 比下肢長

\begin{tabular}{|c|c|c|c|c|c|c|c|c|c|c|c|c|c|c|c|c|}
\hline \multirow{3}{*}{ 年 } & \multicolumn{2}{|c|}{$=$} & \multicolumn{2}{|c|}{ 世 } & \multirow{2}{*}{\multicolumn{2}{|c|}{ 本 國 }} & \multicolumn{2}{|c|}{ 人(田原) } & \multicolumn{4}{|c|}{ 独逸ミニンヘン學童 } & \multicolumn{4}{|c|}{$\begin{array}{l}\text { Schaffhauser } \\
\text { (Schwerz) }\end{array}$} \\
\hline & \multicolumn{2}{|c|}{$\delta$} & \multicolumn{2}{|c|}{ 우 } & & & \multicolumn{2}{|c|}{ 우 } & \multicolumn{2}{|c|}{$\delta$} & \multicolumn{2}{|c|}{ ㅇ } & \multicolumn{2}{|c|}{ t } & \multicolumn{2}{|c|}{ 우 } \\
\hline & $\mathrm{cm}$ & $\%$ & $\mathrm{~cm}$ & $\%$ & $\mathrm{~cm}$ & $\%$ & $\mathrm{~cm}$ & $\%$ & $\mathrm{~cm}$ & $\%$ & $\mathrm{~cm}$ & $\%$ & $\mathrm{~cm}$ & $\%$ & $\mathrm{~cm}$ & $\%$ \\
\hline 6 & 56.1 & 50.5 & 58.4 & 51.9 & & & & & 57.3 & 51.5 & 57.0 & 51.7 & 57.4 & 50.1 & 57.5 & 50.5 \\
\hline 7 & 60.4 & 52.3 & 61.3 & 52.8 & 54.0 & 49.1 & $\$ 3.2$ & 49.1 & 604 & 52.0 & 60.5 & 52.5 & 59.5 & 50.9 & 59.7 & 51.2 \\
\hline 8 & 64.1 & 53.6 & 63.8 & 53.2 & 57.5 & 50.1 & 56.7 & 50.1 & 63.9 & 52.7 & 63.9 & 53.1 & 61.6 & 50.9 & 63.6 & 51.3 \\
\hline 9 & 67.4 & 53.7 & 66.8 & 53.6 & 598 & 50.5 & 57.6 & 50.6 & 67.4 & 53.2 & 67.6 & 53.8 & 66.5 & 51.9 & 66.0 & 52.4 \\
\hline 10 & 71.4 & 54.4 & 70.5 & 54.4 & 62.5 & 50.6 & 62.4 & 50.6 & 67.9 & 53.7 & 69.7 & 54.1 & 69.7 & 52.7 & 69.4 & 52.9 \\
\hline 11 & 73.9 & 54.4 & 73.9 & 54.5 & 65.0 & 50.7 & 65.6 & 51.2 & 72.4 & 54.9 & 73.0 & 54.5 & 71.8 & 52.9 & 72.7 & 53.4 \\
\hline 12 & 77.0 & 54.8 & 78.1 & 54.8 & 68.2 & 51.6 & 68.7 & 51.6 & 75.7 & 54.9 & 75.9 & 54.7 & 74.6 & 53.4 & 77.0 & 54.1 \\
\hline 13 & 80.6 & 54.7 & 79.9 & 54.3 & 71.9 & 52.4 & 72.4 & 51.7 & 78.4 & 55.1 & 79.2 & 55.0 & 78.9 & 54.3 & 79.3 & 54.4 \\
\hline 14 & 84.4 & 54.7 & 81.0 & 53.9 & 76.7 & 52.7 & 75.8 & 52.1 & & 55.2 & & & 824 & $54.4^{\circ}$ & 832 & 54.8 \\
\hline 15 & 86.4 & 54.1 & 81.6 & 53.9 & 79.7 & 52.2 & 77.9 & 52.3 & & 55.2 & & & 84.7 & 55.0 & & \\
\hline 16 & 87.6 & 54.0 & 81.2 & 53.6 & 82.2 & 52.6 & 78.4 & 52.4 & & 54.9 & & & 86.2 & 54.9 & & \\
\hline 17 & 86.6 & 53.5 & 81.4 & 53.8 & 83.1 & 52.1 & 78.5 & 52.5 & & 54.6 & $v^{\prime}$ & & 89.2 & 55.2 & & \\
\hline 18 & 88.0 & 53.5 & 81.8 & 53.4 & 83.7 & 52.3 & 78.4 & 52.3 & & 54.3 & & & 90.3 & 55.0 & & \\
\hline 19 & 86.1 & 53.0 & 83.3 & 53.9 & 83.8 & 52.2 & 79.1 & 52.6 & & 54.3 & & & 91.8 & 55.2 & & \\
\hline 20 & 87.2 & 53.8 & & & 83.9 & 52.1 & & & & & & & 92.6 & 54.6 & & \\
\hline
\end{tabular}


と㱠んど同じ此下肢長を示しているのを見る のである(第 20,21 表).

\section{上肢長及び肢閭示數}

男子上肢長は女子のものより稍々長く，白 人は幼時加ら日本人ょり2糎位大であり，成 人でも日本人は $70 \mathrm{~cm}$ であるか，白人 $73.8 \mathrm{~cm}$ である. 此卟肢長㚾見ても，独逸人 44.5 であ ク，米人は 45.0 で日本人仙 43 である．黑人， アイヌ人は最も長く 46 であり殊にネグ口は前 脯加長心(第 14 表)。

上肢長と下肢長の割合，即古肢間示数も人 種によつて異なつてるる，胎児は上肢長か下、 肢長より長いか出產後は同じ位で示数は 100 であるものが 10〜16才で下肢長か伸び方著し く 83 になり，18〜20 才では上肢長か：伸び方 著しく 86 になる（第 19 聟論文 7 図 発育曲楾 参照). 又闃肢示数に 2 種ある，1 は下肢長全 体と上䁌長全体と此較したものであり，1は 手及び足部の長さを除いたものを比較したも のである.成卡で瑐者 85 內外であり，後者 は70 內外である。各 民族間で肢間示数が違 j. 独人 68(964)，バーデン人 $73.2(967.9)$, 南支那人 71，ジャワ 72.2；ブラヂル，インヂ

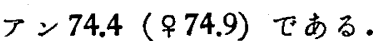

向日本人は新生児の上肢長か：下肢長より短 いか，白人は逆に上䁌長の方が長いことは第 第 19 浴諭文及び本論文一節に詳述した。

二世の肢間示数は 82.7 で日本人の 84.8 に比 し2.1小さいとしてヌ一方比上肢長を見る と二世は日本人ょりやはり，0.35小さいこと 第 3 装に見た通りである。然らば実際に上肢 長か短いのであるか，下肢長が長くなつたた めかこれを確める為めに二世で日本人を同じ 身長のものを選び出し其人に就て調へて見る と, 二世はやはり 1.0 糎短かい，此上肢長で 見ても二世は $0.6 \%$ 小さいのである(第19裴). 何故であるか，說明に苦しむ。

上肢長は寗ろ坐高と一定の比例に発育する
（第 22 表 C） 上肢長 示数表

\begin{tabular}{|c|c|c|}
\hline & \multicolumn{2}{|c|}{ 上肢 長, 坐高示數 } \\
\hline & 成人 。（飯高） & 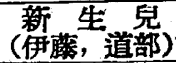 \\
\hline & 79.6 & 59.5 \\
\hline 日本人 & 78.8 & 60.4 \\
\hline 差 & +0.8 & -0.9 \\
\hline
\end{tabular}

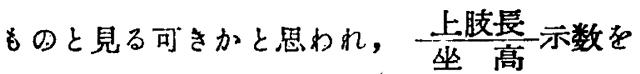
求めて見ると二世桜 79.6 で日本人は78.75とな ク，二世は 0.8 高い， Sh 氏の成緽でる二世忙 63.9 で日本人は 63 となり二世は 0.9 高いこと 同じ率を示した。 二世は坐高が短いにつれて 上肢長が短くなつたと見る可きか子知れない。

（只シャハイイロー氏のハワイ二世の成續で比 上肢長 $0.7 \%$ 長くなつている。之れは手部を 除いた数字であるので，違つたのかもしれな い. 手の長さが新生児に於て己に二世は日本 人ょり $0.2 \mathrm{~cm}$ 短いのを見たからである）(第 15 表). 今後研究しなければならない問題で ある) (第 18 表, 19 表).

胎巟は上肢長か:下肢長より長い，猿は終生 そうである・ネグッは下肢長も長いが上肢長 （特に前膊）か特に長い，白人は出座後は上肢 長か下肢長より長いか，間もなく反対になり 日本人は出産後からッッットうである。

\section{坐高}

各国の比坐高を一一覧すると日本人は最も高 い数を示し $55.3 \%$ である.次で満洲，支那人 で欧州では各国とも大美ないものである（第 $9,10,11$ 表).

比坐高は新生児最も大で下肢長が伸びると 共に比坐高は急に減り第二伸長期の間陎に 11 才゙から 17 才迄最も小さい比坐高となり 18 才 から又坐高が伸びる。女子は 10 才迄は男示と 同しであるが 14 才迄最も小さい此坐高となり 
が同し傾向である．須々木民の女子児童の下 肢長を見ると內地女子览童に比し 7 才〜19 車 平均で 6.9 糎大であることは男子と同じであ る. 身長の差亦 6 8 糎で，この下肢長の差は 即ち身長の差となつているのである．女子の 此下呙肢長を見るに伊藤氏、の世の比下肢長 $50.58 \%$ で，同一の方法で計测した日本队地看 護婦は 50,28\%で 0.3\% の差を示した。

Sh 氏の成績では二世は下肢長 3.54 糎長く 比下肢長 $2.0 \%$ 大きくなつてるる。

比下肢長は 欧米人では男子が女子ょり常に 大きいのであるが，我国では同じ大きさであ るが二世ではやはり男子が大である。

第 21 表 A 各民族の比下肢長

\begin{tabular}{|c|c|c|}
\hline 人 璉 別 & $\delta$ & 웅 \\
\hline 大 露 人 & 51.1 & 50.6 \\
\hline ポール秵太 & 52.2 & 52.0 \\
\hline$=1 \times 1$ & 53.3 & \\
\hline 獨 魀 人 & 53.8 & 54.1 \\
\hline ノールゥエー人 & 54.3 & 52.9 \\
\hline 馬 來 人 & 53.6 & \\
\hline 安東 人 & 52.2 & \\
\hline
\end{tabular}

第21表B 幼兒下肢長

\begin{tabular}{|c|c|c|c|c|}
\hline & \multicolumn{2}{|l|}{ 白 } & \multicolumn{2}{|c|}{ 日本人（飯高） } \\
\hline & $\delta$ & \& & $\hat{o}$ & 우 \\
\hline O(新生兒) & \multirow{2}{*}{\multicolumn{2}{|c|}{${ }_{\text {Taylor }}^{19.0} 18.8$}} & 19.2 & 19.4 \\
\hline 6 月 & & & 26.1 & 30.3 \\
\hline 1 才 & & & 30.6 & 33.5 \\
\hline 2 & & & 36.9 & 36.6 \\
\hline 3 & & & 43.7 & 44.3 \\
\hline 4 & & & 48.1 & 47.2 \\
\hline 5 & \multicolumn{2}{|c|}{ Schaffhauser } & 51.6 & 51.9 \\
\hline 6 & 57.4 & 57.5 & 54.0 & 56.7 \\
\hline
\end{tabular}

次に発充時期に於ける內外のるのを比較せ ん. 田原盛氏のるのは大正 13 年であるか: 7 手〜20才゙あので之れを表示した。只これは 年令の起算が違うので夫れを換算し，且， マ
ルチン氏の一定恒数を減し，且夫れの比下抆 長を表示した．表に就て之れを見れば 7 才に 於て二世は 6 糎大であり年と共に增大し，12， 3 才では 9 糎の差となり，15 才以上になつて 其差急減し， 4 糎內外となる。比下䁌長を見 ても 6,7 才は $3 \%$ の差で，13 才以上になると $1.5 \%$ の差となる．近くは堂園壯意氏の度応大 学のものがあり，昭和 19 年6才〜 14 才 623 名を計测したものであるか，6才 $49.9 \%$ で 14 才は最長の比下肢長を示し 53.3 ( $952.5 \%$ )を 示している.12〜14才は一番高い数字を示す 年令でもあり從來の数字より $0.6 \%$ 大きいか， 近來下肢長は伸びてをる。るれでる二忖の $54.8 \%$ に比し $1.5 \%$ 小である。

㳄に首人の下䁌長と比较して見ん，第 2 節 に述べた如く新嘋児の下肢長は，米白人の下 䁌長より男子 $0.8 \mathrm{~cm}$ ，女子 $1.8 \mathrm{~cm}$ 大きい，し かし白人の下肢長はすぐ伸びて 6 才で己に日 本人ょり $3 \mathrm{~cm}$ (ㅇ 1.5) 長くなる（16表 21 表 B). 比下肢長す日本人最も高く次で二ぜ白 人のは最も低い(15 表)。

次に二世と独逸人の数字と比較せん．此下 肢長を見ると常に一致している。独逸人も，二 世も 12 才 15 才が一生涯中一番高い比下肢長 を示す, 呆18 才以上成人に和つてか，二世 は相当比下肢長が小さくなるか，独婏人は依 然と高い数字を示して居る。

次に女字児童に就て見るに二世と日本人と は 7 才〜13 才ままて 8 糎の差があり，14 才で 5 糎に娍り，15 才以上では 3 糎の差となつてい る. 独逸女子䝨童に比して各年令共 1 糎以下 の差で相一致している. 二世の比卡肢長と日 本人とを比較すると 7,8 才て $3.5 \%$ 仿大であ ク，15 才以上は $1.5 \%$ 大である.二性 人と此較すると 13，4才までは大差ないか， 成人になり 18 才以上になると $1.0 \%$ 位小であ ること，年令的差はあるが男子と同率である。 本邦人の下肢長は最も短い民族とされてい たか，一代代移住にょりかくも伸びて独て人 
头で坐高が発育して $1 \%$ 以上男子ょり大きい 数を示すものである.然るに日本人㞲男女同し 比坐高を示す (22 表). 及二世に就て見ると上 述の如く絕対数は二世の方か:1.4 糎高くなつて いるが身長が高いためである.身長の差 $5.4 \mathrm{~cm}$ の $25.5 \%$ でる。故に，此号高は二世は 54.1 $\%$ で $1.2 \%$ 小さくなり，一定期間日本で大き くなつた二性は絕対数でより 0.8 粝高くなつ ているが比坐高に於て $0.9 \%$ 小である．更に 女子に就て之れを見ると伊藤氏の研究にて二 世は 84.88 糎で一時日本に㕕つた帰米二世は 83.96 粝である。日本人の 82.9 糎に比し絕対 数で 2.0 糎大である。身長の美 4.8 粝の $42 \%$

\begin{tabular}{|c|c|c|c|}
\hline \multirow{2}{*}{ 國人名 } & 比 & 高 - & \multirow{2}{*}{ 研究者名 } \\
\hline & $\delta$ & q. & \\
\hline 丁 抹人 & & 53.6 & Schaller \\
\hline$=$ 索人 & 51.5 & & \\
\hline フランス人 & 520 & 53.6 & Godin \\
\hline 獨 逸 人 & 52.0 & 52.9 & Bach \\
\hline 獨 逸 人 & & 53.0 & Fehlinger \\
\hline 南 露 人 & & 53.7 & Weissenberg \\
\hline$\gamma 1 又 \hat{\imath}$ & & 53.4 & 小 金 井 \\
\hline 日本人 & 55.3 & 55.3 & 塚田，鈴木 \\
\hline 北支那人 & 53.7 & & \\
\hline 滿 洲 人 & 54.0 & & \\
\hline
\end{tabular}

第 22 表

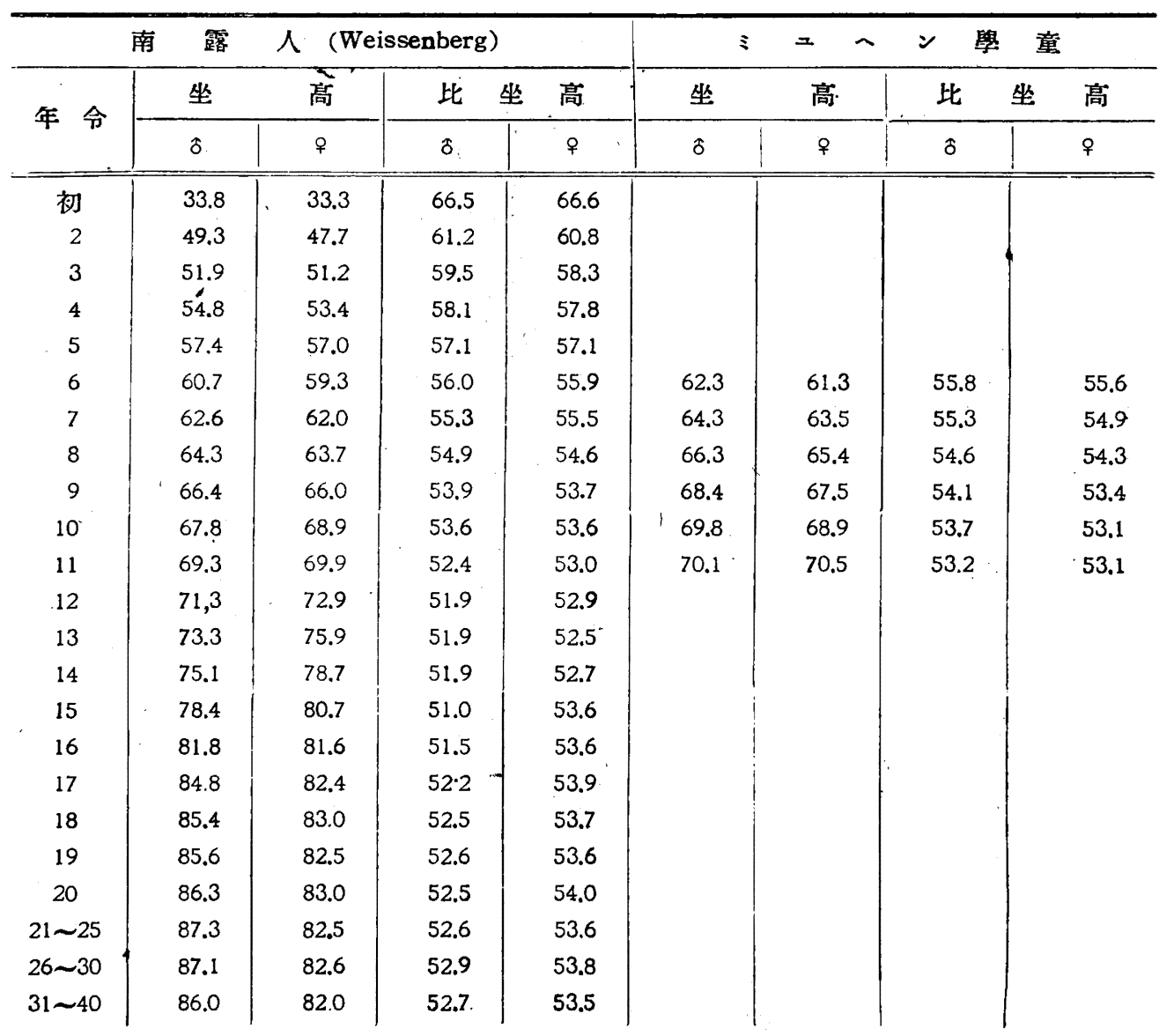


である。

让㙜高を見ると二世住 55.12 で一定期間日 本に 居た二世は 少し高く55.3で 0.2 大であり 內地日本人の 55.4 に比し僅加に 0.3\% の差を 示すのみである。男子の $1.2 \%$ 䇉というの と大きな差違であるが同し傾向である。

次に坐高の発育に就て見るに，新生児では 白人の方か： $3 \mathrm{~cm}$ 大で2才て $1 \mathrm{~cm}$ 其後等しく なり6才からは日本人の方か高くなる。二世 は新生览で米人と日本人との中間で初まり其

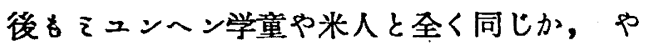
や大きいかであるが，南露人に比し各年令 3 〜 糎程大である(第 $10,11,22$ 表).

让坐高 新生児で日本人は白人上り $3 \%$ 小 さいか: 4 才で己に $1 \%$ 高く，6才で $2 \%$ 高く なつている．二世を見ると新生巟の時から日 本人と米人との中間で，幼時る日本人ょり $2 \%$ 低く，米人上り $2 \%$ 高く各年令に平行してい
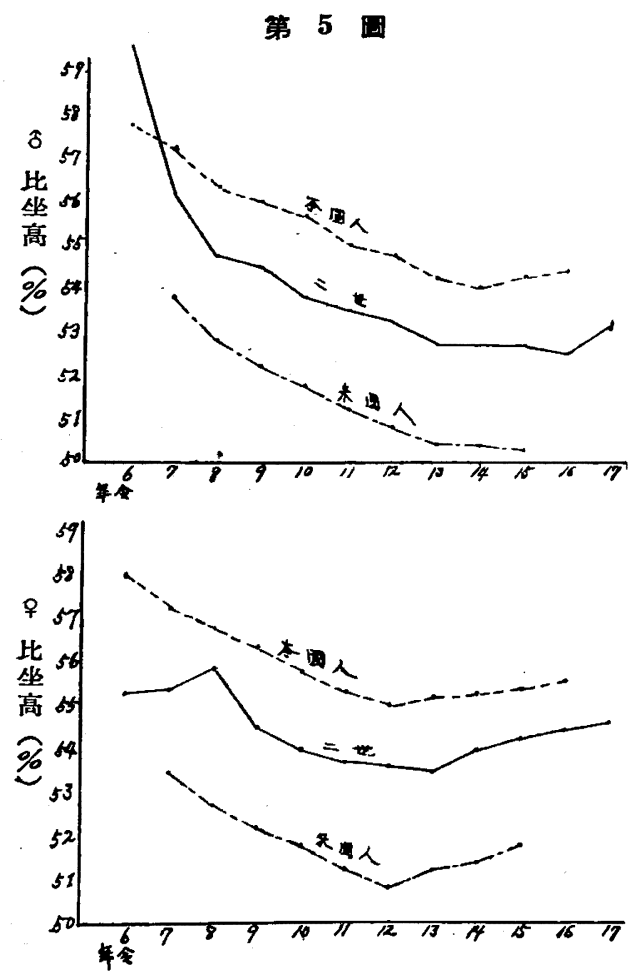

ること 5 図に見る通りである。やはり日本人 は坐高の高い人種なのであ万う(第 2 図).

此坐高の分布度を見ると第 23 表に示すが如 く比坐高 $54 \%$ のものと，53\%のものとで 61 \%となり最も多く，明らかに二世の比坐高は 小さい，更に身長 158 万至 162 糎の日本內地

第 23 表 二世の比坐高分布

\begin{tabular}{c|c|c||c|c|c}
\hline 比坐高\% & 人員 & $\%$ & 比坐高 & 人員 & $\%$ \\
\hline 48 & 3 & 1.16 & 54 & 93 & 36.05 \\
49 & 4 & 1.55 & 55 & 30 & 11.63 \\
50 & 0 & 0 & 56 & 21 & 8.14 \\
51 & 8 & 3.10 & 57 & 1 & 0.39 \\
52 & 31 & 12.01 & 60 & 1 & 0.39 \\
53 & 66 & 25.58 & & &
\end{tabular}

人とほろ゙同し身長を有する二世の 47 名の坐高 を見ると 87.4 糎で，その比坐高は 54.6\%であ る.故に內地の $88.5 \mathrm{~cm}$ に比へるる 1.1 糎だ け小である．其比坐高は $54.6 \%$ で內地の人 55.3 より $0.7 \%$ 小である。

更に下肢長を調べて見ると83.1で日本內地 人の 82.2 糲に比し 0.9 糎大である。換言すれ ば日本人と同じ身長の人を詳しく研究すると 坐高か: 1.1 糎小く，下䁌長か０.9 粝大であると 云う最も注意すべき数字を示したのである.

二編 2 節に詳述したか：女子二世は 日本人に 比し比坐高か： $0.3 \%$ 小さくなり，比下肢長は 全く同率に大きい，Sh 氏の成續では 此坐高 $0.7 \%$ 小さく, 比下肢長 $2 \%$ 伸びている．（3 蓈)

二世は何れの研究も常に內地の人ょり脚が 長くて胴か短い，殊に二杫の日本人と同身長 の人を研究すると 1.1 糎だけ坐高が短く，下 肢長か: 0.9 粝長くなつている (第 19 表). 坐居 が下肢長の発育を，抑制して却つて坐高か;伸 びて居る証左になるやに思われて最も興味深 心凡て生物は一方の発育を抑制方ると他方 に発育することは，しばしば見る現象である 
からである。

次に米国以外の国に発育した二世の下肢長 及び坐高の関係を二㤌の夫れと比較して見る。

玉讲氏の研究による比島に成育した二世日 本人 211 名の坐高を見る：・比帛育ち二世の 坐高法本国人の坐高に比し 8 才〜 14才で 4 9 糲小であり，米国㕕ち二世に比し 3 粝小であ るの屾身長が小であるためである。故に比坐 高を見ると7才〜14才で 0.5〜1.9\%小であり， 米国育古二世に比し $0.7 \sim 1.3 \%$ 大である．換 言すれば米国育ちは比坐高は最も短い次で比 島育ちでおる。更に塚田氏は南洋㮐れ二世 56 名（內 5 名は內地生れで南洋で発育したもの） について坐高を調へたものに就て見ると，

\begin{tabular}{|c|c|c|c|c|c|}
\hline \multicolumn{3}{|c|}{ 比 } & 坐 & \multicolumn{2}{|l|}{ 高 } \\
\hline & 南 & 洋 & 日本人 & 米國二世 & 獨逸人 \\
\hline 11 才。 & & 0.36 & 55.0 & 53.5 & 53.2. \\
\hline $11 \%$ & & 0.33 & & & 53.1 \\
\hline
\end{tabular}

南洋育ち二世は表に見る如く日本人より 0.7
\%小であるが米国㕕ち二世に比へると0.8\%大 である。換言すれば米国育ち三世は最も坐高 が低い，次で南洋育ち比島等で日本人は最も 高いのを知る。

\section{第 3 節 頭部示数の筱化に就て}

䫓彥は 186.4 粍で解剖学会で示した 185.90 粍，塚田博士の宗した 185.3 粍にほろ近似して いるが，中山氏の示した青森県人の 189.3 粍， 秋田県人の 190.3 籷古屋博士の示した北陸地 方の 188,1 粍より小で，安藤氏の示した 金沢 市人 191.5 粍或は 193.3 粍よりはるかに短い数 字である. 又隣邦民族の白老アイヌ(中山) は 195.7 饿, 北海道アイメ (古屋) 195.4粍, 櫵 太フイヌ (古屋) 196.9 粍等に比しては著しく 短い。

品幅は 158.9 粍で解剖学会の 155.6 籷, 長野 県人 (山內, 平沼) 154.1 粍, 近畿地方 (中山) 153.1 粍, 大分県人（西岡）152,9粍，東京產 業人（塚田）152.4 籷等に比しては 6 粍大であ る.隣邦の民族と比較すると，白老フイメ 第 24 表 頭型の分布

\begin{tabular}{|c|c|c|c|c|c|c|c|c|c|c|}
\hline 二 世 & 長 & $\begin{array}{l}\text { 型 } \\
74.9\end{array}$ & $\begin{array}{l}\text { 中 } \\
\text { mess } \\
75\end{array}$ & ph & $\begin{array}{r}\text { 短 } \\
\text { brac } \\
80 \\
\end{array}$ & eph & $\begin{array}{r}\text { 過 } \\
\text { Urtrab } \\
85 .\end{array}$ & $\begin{array}{l}\text { 型 } \\
\text { hyceph } \\
\longrightarrow\end{array}$ & & \\
\hline 一時日本育千 & 0 & $0 \%$ & 1 & $4.3 \%$ & 12 & $52.2 \%$ & 10 & $43.5 \%$ & 23 & $100 \%$ \\
\hline$\therefore \nabla 1$ & 0 & 0 & 6 & 7.3 & 23 & 28.1 & 53 & 64.6 & 82 & 100 \\
\hline 米本 國 & 1 & 0.6 & 17 & $11 . i$ & 70 & 45.7 & 65 & 42.5 & 153 & 100 \\
\hline 總 & 1 & 0.4 & 24 & 9.3 & 105 & 40.7 & 128 & 49.6 & 258 & 100 \\
\hline
\end{tabular}

（中山） 151.1 籷, 北海道アイヌ (古屋) 149.3 粍，樺太アイヌ(古屋) 151.6 粍などに比較し て 8 粔大である：朝解人では済州島（小浜， 佐藤) 158.3 籷, 全羅南道 (荒瀬) 154.3 籷に 比較しても大である.蒙古人，喀爾喀族 158.4 粍，巴爾虎族 161.6 籷と，相似した数字を示し ている。

次に頭示数に就て見るに全国的に見て，表 の如く欧州人は 77 位で, 東洋に至るにつれ示 数は大きくなる。正の頭示数は 85.21 危示し
マルチン氏の 分類により其の分布を示せば上 表の通りである（第 24 表).

第 6 図に見る如く短頭型のものは著しく多 数でこれをがラフで見れば明瞭である。例え ば內地で最も大きい数字を示しているのは解 剖学会の 83.8 で, ついで塚田博士の東京産業 人の 80.8 であるが，他は大低 77〜81 である。

長野県人 (山田, 平沿) 81.7, 近畿地方人 (中山) 81.9 , 大分県人 (西岡) 81.0, 薩摩人 (小浜) 81.2, 大隅人 (小浜) 81.2 , 南九州人 
第 24 表 頭 示 數

\begin{tabular}{|c|c|c|c|c|}
\hline 人種 & $\hat{o}$ & क & 著 & 名 \\
\hline オ一ストリア人 & & 74.2 & Deniker & \\
\hline エシフト (Kharga Oase) 人 & 74.8 & & Hrdlička & \\
\hline ア 1 又 (北海道) 人 & 77.3 & 78.4 & 小 金 井 & \\
\hline$x x-\overrightarrow{7} 2 人$ & 77.3 & & Retzius u Fürst & \\
\hline $1 \neq y$ ○ & 77.6 & & Beđdoe & \\
\hline イキリス (Wales) 人 & 78.7 & & Beddoe u Venn & \\
\hline ルウェ一人 & 78.0 & & Arbo & \\
\hline スペ $1=人$ & 78.1 & & Oloriz & \\
\hline 中華人 (Setschuan) 人 & 79.3 & & Legendre & \\
\hline バルガリア人 & 79.7 & & Wateff & \\
\hline ヘ ル $\neq-1$ & 80.5 & & Houzś & \\
\hline 滿 洲 人 & 79.4 & & 島 井 & \\
\hline カルムッヶン人 & 81.1 & 82.6 & Koroleff & \\
\hline 白 露 人 & 82.4 & 82.2 & Roshdostwenskie & \\
\hline ヒキリッビン人 & 82.3 & & Bean & \\
\hline 江厂 & 84.4 & & Boas & \\
\hline 朝 鲜 人 & 84.6 & & & \\
\hline $\begin{array}{l}\text { 蒙古人（ギリャーク） } \\
\text { カルホルニア・インデアン }\end{array}$ & $\begin{array}{l}84.9 \\
89.7\end{array}$ & 89.9 & $\begin{array}{l}\text { 棤 } \\
\text { Boas }\end{array}$ & \\
\hline
\end{tabular}

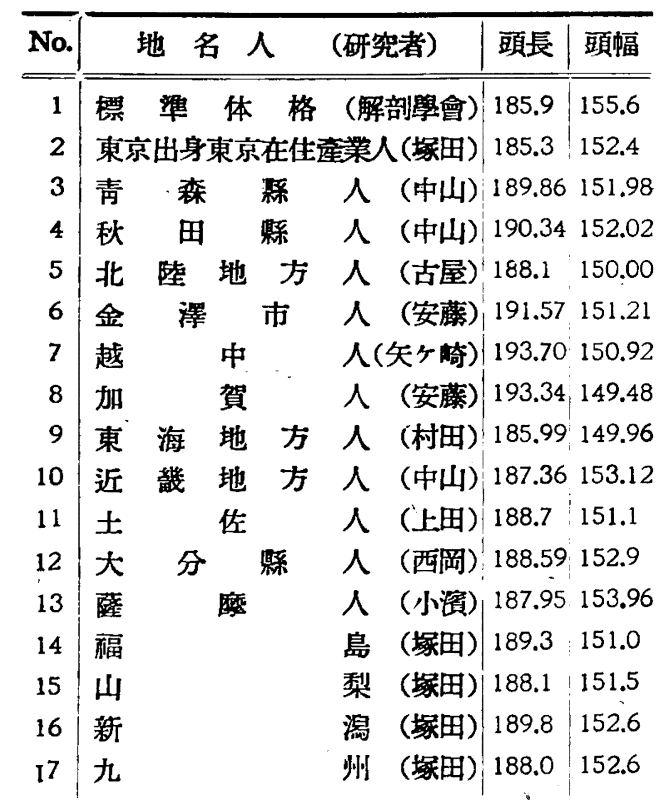

（小浜） 81.8 等で何れも中頭型の最も短頭に近 いものである・最も小さいのは越中人（殡ケ
崎) 77.9, 金沢市人（安藤） 78.9, 加賀人（安 藤) 77.3 , 北陸地方人 (古屋) 80.1 等は中頭型 である。是等の計测を見ると解剖学会で調查

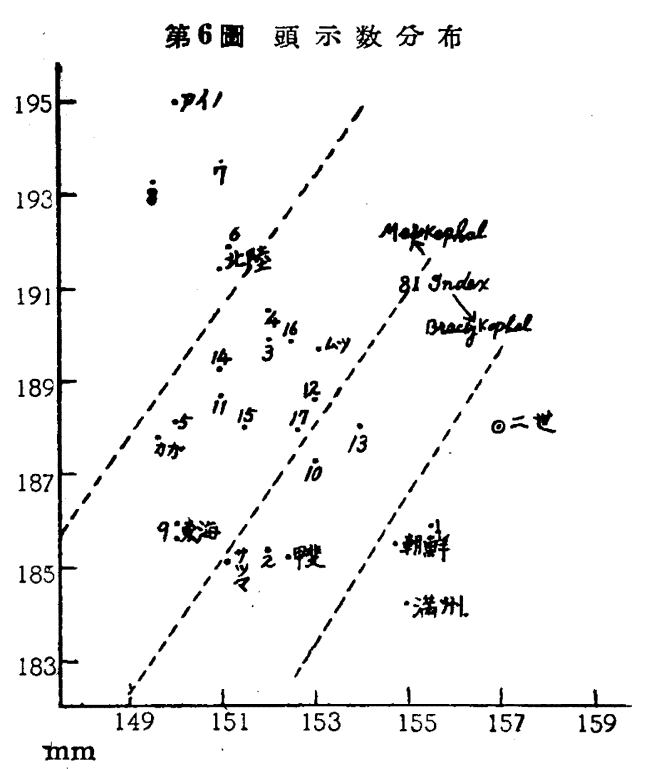


したものが頭幅最も大きく指数も大きいが二 世面に大きい。

地域的に見ると九州西部, 北陸山陰. 伯耆, 最も小で長頭の方であり北海道, 東北も，次で 小さく．東海道，沂畿これに次さ，九州南部 ，中国，信濃梳すつと大きく短頭の方である。 更に隣邦民族に比較すれば白老つイヌ（中山） 77.2,北海道フイヌ (古屋) 76.5 等に比較して 著しく短頭であつて朝鮮人済州島 (小浜, 佐 藤) 85.9 に近く蒙古人（錫林郭勤，橫尾） 82.7, ギリャーク (僙尾) 84.9 に近い数字であ る(6図).

上迅の結果を見て二世は頭長は東北，北陸 上り短く，全国平均数に近く，顽幅は全国平 均よりも， 又近畿中部より6粔も大である。 從つて頭示数は上記全体の平均 80.7 というに 比し二世は85.21 と4.51大きくなつている。 即ち日本人は中頭型と短頭型の間に位してい るが、二世は著しく短頭になり，殆んど全部 短頭と過短頭とである。

又其分布度を見ても $40.7 \%$ は短頭型に属し 過短頭型も $49.6 \%$ 算している.（24 表）

これは，大学專門学校学生の如く又二世の如 く采荃, 教育良好の者か沶数大きく, 頭幅も 示数も大きいのであ万う（俗間日本では頭幅 の大きい人は利潑であるという：欧州では頭 長の大きい人が利没であるという).

次に米国以外の地域で成育した二世の頭示 数に就て見るに表に示すが如く短頭型乃至過 短頭型になつている。
塚田氏表 南洋に於ける各民族の頭示数

\begin{tabular}{|c|c|c|c|c|c|}
\hline \multirow[b]{3}{*}{11 才。 } & \multirow{3}{*}{ 南洋育 } & \multirow{3}{*}{ 日本人 } & \multirow{3}{*}{ 歌人 } & \multicolumn{2}{|c|}{ 因人南洋移民 } \\
\hline & & & & 頭示數 & 81.5 \\
\hline & & & & 頭 偪 & 15.0 \\
\hline $12 \%$ & 87.3 立 0.79 & 84.8 & 81.9 & 頭 長 & 14.6 \\
\hline
\end{tabular}

頭型の分類を見ても次表に見る通りに日本 人とは非常に違つた分布状てある。

\begin{tabular}{|c|c|c|c|}
\hline 長 頭 & 頭 & 短 頭 & 過 短 頭 \\
\hline & $76 \sim 80.9$ & $81 \sim 85.4$ & $85.5 \longrightarrow$ \\
\hline & $3(5.7 \%)$ & $17(32.1 \%)$ & $33(62.3 \%)$ \\
\hline
\end{tabular}

しかし若い年令では頭示数は 90 ののもあ ク,こ.ろには色々の年令の人があるので何と も云い得ない(第 19 卷, 頭示数の項参照). し かし江口氏の南洋移住民及び該地二世の研究 は興味あるものである。不表の如く 1.7 大き い.これは 53 人の成年 (18 才以上)（闪 1 人 は南洋㢅れで他は 4, 5 才で南洋に渡り成育し た人）の検査である(第 19 讼，第 9 図参照). 中沢氏は 日本大学入学生等 4,990 名につき， 6 大都市の人が 頭示数平均 0.45 大きくなると 指摘した。．大学生等の示数であるから一般よ り大きくなっている。

しかし 欧州では都市生活者は 田含居住者に 比し長頭型の\%が多くなつたとゆう調查があ る. 欧州とは違うのかも知れぬ，日本でも都 中澤氏表

\begin{tabular}{|c|c|c|}
\hline & 年 命 & $\mathbf{M} \pm \mathbf{m}$ \\
\hline \multirow{3}{*}{ 中小都方 } & 17 才 & $84.59 \pm 0.24$ \\
\hline & $18.19 \prime \prime$ & $84.57 \pm 0.19$ \\
\hline & $20-$ & $84.18 \pm 0.25$ \\
\hline \multirow{3}{*}{ 六大都市 } & 171 & $85.32 \pm 0.22$ \\
\hline & $18.19^{\prime \prime}$ & $84.97 \pm 0.19$ \\
\hline & $20-$ & $84.41 \pm 0.18$ \\
\hline
\end{tabular}

江口 氏表

\begin{tabular}{|c|c|c|c|c|}
\hline & 南洋移民成人 & 우 & 南洋育ち成人 & 差 \\
\hline 長 & $18.6( \pm 0.27)$ & $17.6( \pm 0.32)$ & $18.4( \pm 0.42)$ & $0.2( \pm 0.50) \quad(\mathrm{D} / \mathrm{mD} \quad 0.4)$ \\
\hline 頭幅 & $15.0( \pm 0.35)$ & $14.5( \pm 0.47)$ & $15.2( \pm 0.49)$ & $0.2( \pm 0.60)(\mathrm{D} / \mathrm{mD}))$ \\
\hline 頭 示 數 & $81.5( \pm 0.24)$ & $81.6( \pm 0.40)$ & $83.2( \pm 0.45)$ & $1.7( \pm 0.51) \quad(\mathrm{D} / \mathrm{mD} 3.3)$ \\
\hline
\end{tabular}


市と農村とを比較して見たい。1924年には Fischer u. Neubauer 両氏は白鼠にビタそ ン欠食を長く与うれば，ビタそン食を給与す るるのに比し長頭型に変はるを証した。

Boas 氏仗欧州上り米国に移民し 20 年以上 たつたものは段々に欧州型を脫し米国の一定 の型になる如く,81より大きいものは小さく， 81 より小いものは大きくなると次の数字を 挙げてるる。

\begin{tabular}{|c|c|c|}
\hline & $\begin{array}{l}\text { o(20年 } \\
\text { 以上) }\end{array}$ & 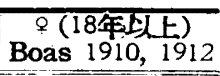 \\
\hline 歐州に生れし唒太人 & 83.0 & 83.6 \\
\hline 米國に座れし唒太人 & 81.4 & 82.3 \\
\hline 歐州に库狄白人 & 77.7 & 77.8 \\
\hline 米國に圱玌し白人 & 81.5 & 80.3 \\
\hline
\end{tabular}

Shapiro はハワイの二世と日本人移民を調 查し，移民したらけでは頭率は変異しないが， 二世では著しく変異し頭率も 3.4 增大したの を見てるる。
Sh. 氏 表

\begin{tabular}{|c|c|c|c|}
\hline . & 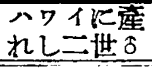 & 移 住 民 & $\begin{array}{l}\text { 內 地人 } \\
\text { (臣島) }\end{array}$ \\
\hline 長 & 186.18 & 189.68 & 189.02 \\
\hline 幅 & 155.28 & 151.5 & 151.6 \\
\hline 頭示數 & 83.8 & 81.0 & 80.4 \\
\hline 頭 高 & 13.68 & 13.41 & 12.73 \\
\hline
\end{tabular}

第 4 節 点示数，顔示數，肩幅，腰幅 に就て

二世に及ぼす尊型の変化を見たものにシヤ パイー氏のハワイのるの及び比島に於て江 口氏のものがある.

移民の·鼻示數表

\begin{tabular}{|c|c|c|c|c|}
\hline 著者 & \multicolumn{2}{|c|}{ Shapiro } & 江 & 口 \\
\hline 人稙 & 百本 & 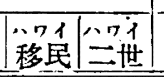 & 南洋移民 $\delta$ & 南洋二世 \\
\hline 累高 & 46.7 & $50.46 \quad 49.84$ & $54 \pm 0.42$ & $54 \pm 0.56$ \\
\hline 鼻幅 & 35.28 & \begin{tabular}{ll|l}
34.96 & 33.74 \\
\end{tabular} & $36 \pm 0.24$ & $34 \pm 0.34$ \\
\hline 悬示數 & 69.92 & 70.4865 .38 & $67.4 \pm 0.53$ & $63.4 \pm 0.73$ \\
\hline
\end{tabular}

移 民 の旡 示 數 表

\begin{tabular}{|c|c|c|c|c|c|c|c|c|c|}
\hline \multirow{2}{*}{ 人種 } & \multirow{2}{*}{$\mid \begin{array}{c}\text { ワイ移民 } \\
\text { (シャバイ } \\
\text { 口-氏 }\end{array}$} & \multirow{2}{*}{$\begin{array}{l}\text { ヘワ } \\
\text { 二世 } \\
\end{array}$} & \multirow[t]{2}{*}{ 南洋移民 } & \multirow{2}{*}{\multicolumn{2}{|c|}{$\begin{array}{c}\text { 南洋二世 } \\
\text { (江 } \quad \text { 口) }\end{array}$}} & \multirow{2}{*}{$\begin{array}{l}\text { 日本人 } \\
\text { (西) }\end{array}$} & \multirow{2}{*}{$\begin{array}{c}\text { 日本人(塚田) } \\
. \\
\end{array}$} & \multicolumn{2}{|c|}{$\begin{array}{c}\text { 瀷 } \\
\text { (Schaffhauser, } \\
\text { Schwerz) }\end{array}$} \\
\hline & & & & & & & & 8 & \% \\
\hline & 141.96 & 142.20 & $142 \quad \pm 0$ & 139 & $( \pm 0.45)$ & 139.9 & $139.75( \pm 0.10)$ & 138 & 129 \\
\hline & 123.74 & 119.87 & $12 z( \pm 0.30)$ & 120 & $( \pm 0.49)$ & 123.0 & $124.22( \pm 0.10)$ & 125 & 110 \\
\hline 願示數 & 87.13 & 84.40 & $85.5( \pm 0.43)$ & 86.7( & $( \pm 0.45)$ & 88.4 & 88.9 & 90.5 & 85.4 \\
\hline
\end{tabular}

両者の成績を見ると悬高は各々其親と同じ であるが鼻幅が粍程小となり從つて示数はハ ワイに於て 4.5, 此島に於て 4.0 たけ 小となつ ている，両者か同率を示していることは興味 あることである（第19 缭，第 11 図参照).

浐型に就て見るに同しくシャバイロー氏の ものと江口氏の南洋諸島のもの,とがある。

之等の成績を見ればハワイ二世は観骨幅は 殆んと善なく，南洋二世は小さくなつてるる。 日本人と移民との差は恐らく計测による差と 思的。
顏高はハワイ二世は $3.87 \mathrm{~mm}$ 短く南洋の二 世も 2 粍小さくなつて現われている。

従つて顏示数もハワイ，南洋共に日本人よ り 2.7 或は 1.7 だけ小さくなっている.(昌本人 は独人に比し 観骨幅が大きいため示数は大き œ.)

肩幅は二世は広い、日本人としては堂園氏 のものと比較すれば男女共 6 才〜 13 才までは 1.5 粝大きい，乙かし 14 才以後は竹內氏の のと比較すれば僅かの差であるか女子成人の 二世は 35.2 で本人の $33.7 \mathrm{~cm} ょ り 1.5 \mathrm{~cm}$ 大 
第 25 表局幅及び比肩幅

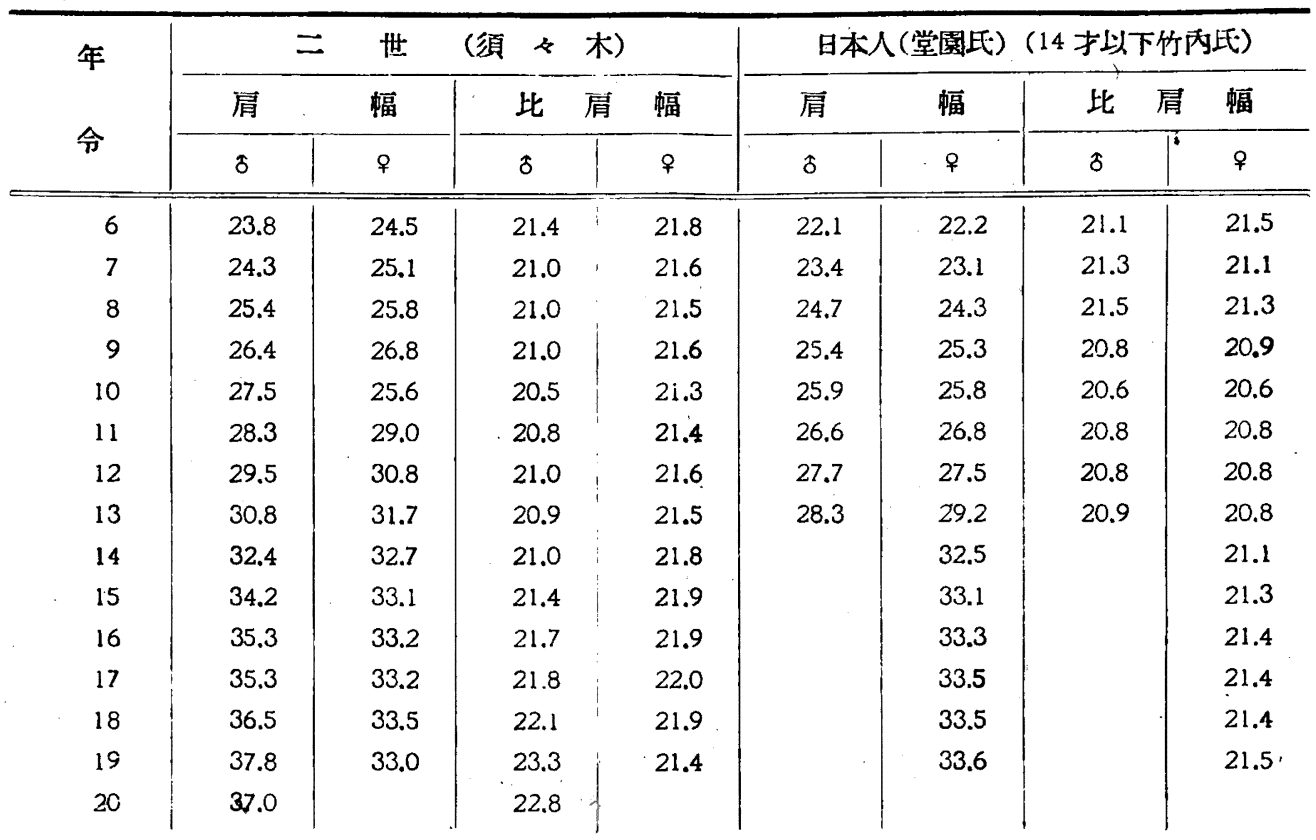

第 26 表 腰幅及比腰幅

\begin{tabular}{|c|c|c|c|c|c|c|c|c|c|c|c|c|c|c|c|c|}
\hline \multirow{3}{*}{ 令 } & \multicolumn{4}{|c|}{ 二世 (須々木) } & \multicolumn{4}{|c|}{ 日 本 人（同上） } & \multicolumn{4}{|c|}{$\begin{array}{l}\text { ミニンへン (Martin } \\
1920 \text { 年) (14 才以下 } \\
\text { Ried. } 1925 \text { 年) }\end{array}$} & \multicolumn{4}{|c|}{$\begin{array}{l}\text { 南露 = } \\
\text { (Weissenberg) }\end{array}$} \\
\hline & \multirow{2}{*}{$\begin{array}{l}\text { 腰 } \\
\delta\end{array}$} & \multirow{2}{*}{$\frac{\text { 幅 }}{\circ}$} & \multicolumn{2}{|c|}{ 比腰幅 } & \multicolumn{2}{|c|}{ 腰 幅 } & \multicolumn{2}{|c|}{ 比腰 幅 } & \multicolumn{2}{|c|}{ 腰 幅 } & \multicolumn{2}{|c|}{ 比腰輻 } & \multicolumn{2}{|c|}{ 腰 幅 } & \multicolumn{2}{|c|}{ 比腰 幅 } \\
\hline & & & $\delta$ & q & $\hat{\delta}$ & $q$ & $\hat{o}$ & 9 & $\delta$ & q & $\delta$ & q & $\delta$ & $q$ & $\delta$ & $q$ \\
\hline 6 & 18.3 & 17.9 & 16.5 & 15.9 & 18.4 & 18.6 & 17.5 & 17.8 & 20.6 & 20.5 & 16.1 & & 18.4 & 17.9 & 16.9 & 16.8 \\
\hline 7 & 18.4 & 18.2 & 15.9 & 15.7 & 19.4 & 19.1 & 17.4 & 17.6 & 21.2 & 21.1 & 16.0 & & 18.9 & 18.6 & 16.9 & 16.6 \\
\hline 8 & 18.7 & 19.0 & 15.5 & 15.8 & 20.3 & 19.8 & 17.7 & 17.5 & 21.9 & 22.0 & 16.1 & & 19.5 & 19.2 & 16.8 & 16.5 \\
\hline 9 & 19.4 & 19.6 & 15.5 & 15.8 & 21.2 & 21.0 & 17.4 & 17.6 & 22.9 & 22.8 & 16.1 & & 20.2 & 20.2 & 16.6 & 16.5 \\
\hline 10 & 20.1 & 20.9 & 15.3 & 16.1 & 21.5 & 21.6 & 17.3 & 17.4 & 23.4 & 23.6 & 16.2 & & 20.8 & 21.1 & 16.6 & 16.6 \\
\hline 11 & 20.8 & 21.3 & 15.3 & 15.7 & 22.3 & 23.8 & 17.6 & 17.8 & 24.1 & 24.4 & 16.0 & & 21.5 & 21.6 & 16.5 & 16.3 \\
\hline 12 & 21.6 & 22.8 & 15.3 & 16.0 & 23.1 & 24.7 & 17.6 & 17.9 & 25.0 & 25.7 & & & 22.2 & 22.6 & 16.3 & 16.2 \\
\hline 13 & 22.6 & 23.8 & 15.3 & 16.2 & 24.4 & 25.6 & 17.2 & 18.6 & 25.8 & 27.0 & & & 22.8 & 24.1 & 16.3 & 16.7 \\
\hline 14 & 23.8 & 24.4 & 15.4 & 16.2 & & 25.5 & & 17.4 & 25.2 & & & & 23.6 & 25.2 & 16.2 & 16.9 \\
\hline 15 & 24.7 & 25.0 & 15.5 & 16.5 & & 26.0 & & 17.6 & 26.2 & & & & 25.0 & 26.2 & 16.8 & 17.4 \\
\hline 16. & 25.2 & 25.2 & 15.5 & 16.6 & & 26.3 & & 17.7 & 27.1 & & & & 25.8 & 26.7 & 16.4 & 17.6 \\
\hline 17 & 25.2 & 25.4 & 15.5 & 16.8 & & 26.7 & & 17.9 & 27.6 & & & & 26.6 & 27.1 & 16.4 & 17.7 \\
\hline 18 & 25.9 & 25.9 & 15.7 & 16.9 & & 26.7 & & 17.9 & 28.0 & & & & 27.0 & 27.4 & 16.6 & 17.8 \\
\hline 19 & 25.3 & 25.2 & 15.6 & 16.3 & & 26.7 & & 17.9 & 27.9 & & & & 27.4 & 27.5 & 16.7 & 17.9 \\
\hline 20 & 25.6 & & 15.8 & & & & & & & & & & 27.5 & 27.5 & 16.7 & $\$ 7.9$ \\
\hline
\end{tabular}


きい(伊藤氏) .

比肩幅は男子は同しか,や了大きいかで，女

各國人比肩幅

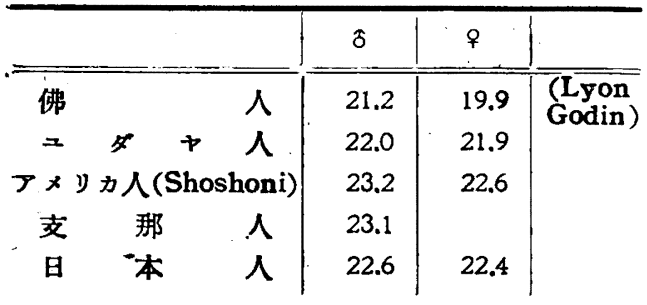

各國人比腰幅

\begin{tabular}{|c|c|c|c|}
\hline 國。 & $\delta$ & $q$ & 研 究 者 \\
\hline シ十人 & 16.3 & & \\
\hline 人 & 16.8 & 18,4 & Godin \\
\hline ハールウェー & 16.6 & & \\
\hline 獨 逸 人 & 17.0 & & Prochowrik \\
\hline 獨 魀 人 & 17.1 & 18.0 & Bach \\
\hline$n-\neg n>$ & 17.2 & & \\
\hline 支 那 人 & 17.7 & & \\
\hline 日 本 人 & 15.3 & 17.4 & \\
\hline$>1 \times 1$ & 17.0 & 18.0 & \\
\hline
\end{tabular}

子も少し大きい（各国成人の比雇幅を見ると 日本人は米人ょり少さい）(第25表).

各国人の比腰幅は第 26 表に見るが如く日本 人だけ 15.3 で最も小さく，佛人心 16.8 , 独人 は 17.0 である・フイヌは 17.0 である。他は大 体等しい。

二世腰幅を日本人（堂園氏）に比較して見 ると，13 才までは $1.5 \mathrm{~cm}$ 程小さい, 14 才以 上を竹內氏のものと比較して見ても，やはり $1.0 \sim 1.5 \mathrm{~cm}$ 小さい. 此腰幅を見ても，男女共 に 2.0 位小さい. 14 才以上も 1.0 以上小さく， 日本人の方が大き。

之れを独逸人に比較して見ると二世の男女 共 3〜 4cm 小さい.14 才以上も 童に比較して見るとやはり $2 \sim 3 \mathrm{~cm}$ 小さい。 比腰幅を見るに，男子は 0,5 小さい，南管人 に比しても男子は 16 拟上で 2 小で，女子は
13 才以上で 1〜2 小である. 日本人は腰幅は 小さい人種であるか，殊に二世は日本人ょり 更に小である。

即ち二世は番幅, 観骨幅, 腰幅, 等の幅は 皆小さくなり鼻示数，顏示数も小さくなる， 只頭巾そ肩幅は大きくなり，頭示数は大きく， なつている.

或人は日わん，身長や体重許り大きくなつ ても，着物は沢山入るし食物は多く要ると， しかし従來の統計でも栄食の砅唀な子, 身長 の高い子の方が成績は良いことを証している し，二世の児童が米国の学校で，一番になり， 優等生になつた話も屡々耳にする，小学校卒 業式で，級総代として謝辞を述べるのは，一番の席次のものが述へるのが例であるが，磨 々二世が一番になり謝辞を述へるのに日本人 系であると云う理由で次席の者が謝辞を述べ させる等で問題になることを姿々聞いている。 又コメリカ陸軍省の 公式調查でる, 壯丁で 4 年制高等学校卒業以上のもの二世は $57 \%$ であ るが、フメリカ白人は 53\%, 欧州からの移住 白人は $48 \%$ であつたと，

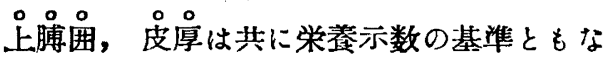
るもので，二世の栄䓹は內地日本人に比し著 しき優秀さを示す最たるものである．栄䓹示 数乃至身長は 知能示数と相関関係のあるこど は己に統計的にも認められていることである。 二世の知能忙果して如何とは当然來る問題で あるる.

依つて二世の知能, 性格, 作業能力, 德義心 なとについて次に䌒めた。栄食，環境の改善 に，日本民族の改善に資するものがあらば望 外の幸である。

\section{第 5 節 二世の知能，性格，作業能揫， 犯罪等に就て}

\section{1. 知能示數に就いて}

先す日本人と各国人と此較した 知能示数に 就て見ん．米国には各国人種の児童がいるの 
で此種の研究には最も良い。最初に日本人を 検查したのは Goodenough. F.L. 氏である。 氏はカルフォルニヤ州で糼稚園や小学校の 児童検査をしたもので次表の通りである。（G 氏表)

表によると最も良いのか支那人で，次でつ メリカ人，次で日本人，英人となり，日本人 は独，伊，佛人ょり優れている，最も惡いの が黑人である。田中寛一博士は北米三都市

G 氏 表

\begin{tabular}{|c|c|c|c|c|}
\hline 民 族 & 中間 數 & S.D. & 人 & 數 \\
\hline 厂×リカ人 & 100.3 & 18.3 & & 500 \\
\hline Fイッ人 & 98.8 & 19.8 & & 29 \\
\hline $\begin{array}{l}1 \neq ゙ リ ス 及 ひ ゙ ス \\
\text { コットランド人 }\end{array}$ & 99.5 & 16.8 & & 14 \\
\hline 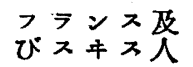 & 92.5 & 19.8 & & 14 \\
\hline 1タリヤ人 & 87.5 & 16.0 & & 456 \\
\hline 南方黑人 & 76.5 & 17.5 & & 613 \\
\hline 支 那 人 & 103.1 & 18.0 & & 25 \\
\hline 日本 人 & 99.5 & 18.0 & & 42 \\
\hline
\end{tabular}

(ロスフンヂルス，サンフラシシスコ,ホンル ル） 5,000名許りの児童を調查したのに次の様 な結果を示している。

田中氏表

\begin{tabular}{|c|c|}
\hline & 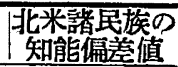 \\
\hline 日 本 人 & 49.92 \\
\hline 支 那 人 & 46.29 \\
\hline 朝 鮮 人 & 46.22 \\
\hline 英 & 44.80 \\
\hline 獨逸人 & 43.88 \\
\hline 1タリア人 & 36.79 \\
\hline ボトガル人 & 41.54 \\
\hline x $\neq$ 泣人 & 37.04 \\
\hline ニダヤ人 (ロシャ) & 45.13 \\
\hline ア $\times$ リカ人 & 44.05 \\
\hline 混 血 兒 & 44.17 \\
\hline 几 71 人 & 39.00 \\
\hline 黑 人 & 35.25 \\
\hline
\end{tabular}

之れで見ると日本人は最す優秀になってい て，次で支那人，朝鮮人良く，ユダヤ人，米 人これに次いで黑人，伊人，メキシュ人等最 も惡い，又支那及び朝鮮国內で支那人，朝鮮人 の览童を調查しここれを日本坚童と比較したる のに次の結果を報告している。即古日本人は 支那人より知能偏差值 2.75 優れ, 其差も蓋然 偏差の 8.2 倍を示し，有意義の美であり.明ら かに日本人の優秀を示している．又朝鮮人 との善は 2.80 で, 且其䒧も蓝然偏差の 4.5 倍 で有意義で 日本人の方が優秀はのを示してい る.

日本人兒童と支那及び朝鮮人との 知能偏差值 (田中)

\begin{tabular}{|c|c|c|}
\hline 人 種 & 知能偏差値 & 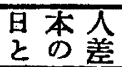 \\
\hline 日本人兒童 & $49.47 \pm 8.90$ & \\
\hline 支那人 " & $46.72 \pm 9.52$ & 2.75 \\
\hline 朝鮮人 " & $46.67 \pm 9.13$ & 2.80 \\
\hline
\end{tabular}

次に米国で二世の 知能示数を調べたものに 1923 年 (大正 12 年) Denver 市 (Colorado)

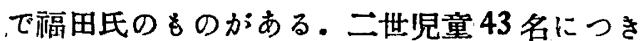
Binet 法で知能示数を求め 97 (最大 143 67) を求め報告した。これが二世の知能示数を求 めたもの3最初だある：其成績の俖秀なのを 見て 1925 年 Sandiford. P. and Kerr. R. 氏 がパンクーバーで 276 名の三世児童と，支那 児童 224 名につき調查し，示数が二世 114.2， 支那児童 107.4 を示している. 㕛欧米人のノル ム以上の成績のもの二世は $80 \%$ あるのを示し た. 三崎氏は昭和 2 年カリフォルニヤにて二 世82名につきビネー式で調查した，氏特に 日本人には英語の不得手があるので二組に分 け一は英語，他は日本語で試驗したのである。 其結果日本語でやうた方が成績が良く両者の 間に 2.4 4.4 月の精神年令の羑を見たのであ る・夫れだけ普通にテストすれば日本人は惡 く成績が出る理である。そこで言葉を要しな いピントナー氏動作検查法で 検查したのに示 
数 112.4 となり,さきの Sandiford 氏の示し た数値に一致したことを示し，Binet の口語 式のものは二世では惡い数字を示すと云つた。

Darsie（1922-24） 氏は 10～15 才览童につ き次の如く知能示数か; 平均して 米人 99.5 , 二 世 89.5 を示した。其分布状態を見ても，や了 二世が劣ることを示した。しかし氏は刃 1925 年サンブランシスコで二世英語に不慣れの ため言語を要しない陸軍式で調查し，12 才て は二世79.5 で米人は 71.7 でり，13求では 二世 82.1, 米人 68.3 であり 二世の方が優れて いると云つた。

Binet I. Q (Darsie 氏)

\begin{tabular}{c|r|r}
\hline$(10 \sim 15 \mathrm{Lj})$ & \begin{tabular}{c} 
米 $\hat{\mathrm{N}}=476$ \\
\hline $136 \sim 145$
\end{tabular} & $\overrightarrow{\overrightarrow{\mathbf{N}}}=570$ \\
\hline $126 \sim 135$ & 5 & 5 \\
$116 \sim 125$ & 1.4 & 1.6 \\
$106 \sim 115$ & 8.3 & 5.8 \\
$96 \sim 105$ & 19.8 & 8.3 \\
$86 \sim 95$ & 31.0 & 18.5 \\
$76 \sim 85$ & 23.2 & 27.4 \\
$66 \sim 75$ & 11.0 & 20.7 \\
$56 \sim 65$ & 4.3 & 12.9 \\
Median & 0.5 & 4.3 \\
& 99.5 & 89.5
\end{tabular}

且又米人のノルム以上に出る二世は $75.2 \%$ あることを示し Sandiford の成績と一致せ るを示したのである。そして二世は英語の意 味や概念に基礎を置く記憶や 抽象的思考には 米人に較へ劣るか，視敩的知営や思考含む 精神作用は米人䝨童より優ること明らかであ ると，そこで両氏は異口同調にこれは日本
民族が優秀であると云うのでなくして，米国 に渡る位の日本人は霸気に富み，利潑勇気を 持つ優秀の人であつて，㭧鈍で覇気にも泛しい ような人は皆本国に残つているためこんな成 績を示すのである. 叉今一つの理由は公立小 学校には二世の児童は皆入学するか， 米人の 良い富裕な家の児童は公立より私立に行くを のが多いからこう云う成績になつたのだろう と結んでいる。後の理由はそうであるかも知 らん，しかし初めの理由は一面の真理はある。 意慢の人は外国にまで踏み出ても食えないか ら，米国に行く位な人は一程度の優秀さは保 つている人であろう，しかし愚鈍な人は內地 に残るという事は全く云え得ないことである。 況んや日本で渡行している人の多数は真の百 姓の人が多かつたようであるからである。

そこで日本民族の知能を論するのに，日本 內地の児童と米国に於ける二世との知能を比 較調查しなければ，一般に日本民族の知能の 云々は論ぜられなくなつた。るこで田中寬一 博士は白本內地の児童として東京, 京都, 名 古屋の 览童 3,000 名, 北米三都市の二世览童 600 名につき調查した。其結果は日本內地の ものより北米のものは優れているか，其恙は 僅かに $0.31 て ゙$, 其 D/P.E.dは 1,15 で有意 の差は示さなかつた。しかし S.D. に就て其 差の信賴度を見ると完全に信賴出來るものて あつた（S.D. の差 1.3 て D/P.E.d の二乘 8.0 であつた). 又其分布曲線を見ても北米のもの が最も高く曲線も左右均等で, 歪み度 (SK) を見ても無視して良い程小さく確かに北米児

田中氏表 各地に於ける日本人の知能テスト

\begin{tabular}{|c|c|c|c|c|c|c|c|c|c|}
\hline \multirow{2}{*}{ 地 } & 方 & \multicolumn{3}{|c|}{ 知 } & 偏 & 美 & \multicolumn{2}{|l|}{ 値 } & \multirow[t]{2}{*}{$\mathbf{n}$} \\
\hline & & $\mathrm{Mi}$ & $\mathbf{M}$ & S.D. & SK & |1と3との迲 & P.E.d & D/P.E.d. & \\
\hline \multicolumn{2}{|c|}{1 內地四都市 } & 49.71 & 49.48 & 10.33 & -0.067 & & & & 3251 \\
\hline \multicolumn{2}{|c|}{2 亞細 亞外地 } & 49.65 & 49.50 & 8.30 & -0.054 & & & & 2756 \\
\hline $3=$ & 米都 市 & 50.18 & 49.79 & 9.04 & -0.129 & -0.31 & 0.27 & 1.15 & 644 \\
\hline
\end{tabular}


童の伾れていることを証するのを見たのであ る.

この結果を見て二つの事を教える. Sandi・ ford p Darsie，の云う様に二世は內地の肾 童より俖れていたのは事実であつたのである。 しかし其差况僅小なものであるから， 日本民

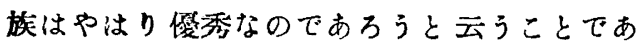
る.今一つは栄餋示数の優れた二世はやはり 知能示数も優れている。しかし其美は小さい ようであるが，渡米した人は日本人として中 或は夫れ以下の人が多いのではなかろうか， そうすれば，其人の児童が日本で最高と思わ れる大都市の览童よりも㕍れているというこ とは，知能示数は著しく優秀化されているの だと日いたくなる所以である。

䌮つて北京，京战，台北等に移住しそそで 産れた二世は內地の児童に比しとうであるか と日うと田中氏の調查ではやろ劣っている。 しかし有意ではないこのことは，日本人の 满洲支那に移佳した人の体位か; 日本內地の人 より劣つていたのと同律に知能もや了低く了 なつているのを見ることも興味あることであ る.

日本人は北米移住により優良化したが他の 国民はとうか，田中博士はホノル、で支那人 览童を調へ，支那內地の児童より 2.85 優れて い，其 D/P.E.d. 65.0 を有意の差を示した
朝鮮人の場合も京战览童とホノル、の朝鮮览 童とを比較し 0.4 の差で有意の差ではなかつ た。しかし北京，京战では裕福览童のみであ つたので相当優れていたと思ふと。

支那, 朝鮮本國內兒童と北米兒裏の比較(田中)

\begin{tabular}{l|l|l|l}
\hline & & 差 & P.E.d. \\
\hline \hline 北 京 兒 童 & $43.47 \pm 9.01$ & 2.85 & 5.00 \\
ホノル、, 妾那人 & $46.32 \pm 9.95$ & & \\
京 城 兒 童 & $45.89 \pm 7.54$ & & \\
ホノル、,朝鮮兒童 & $45.43 \pm 9.29$ & 0.42 & 0.34
\end{tabular}

今度松本助教授に賴み二世の最近の成績を 䁣ねたら，Franklin Berkeley の小学校で 4,5 年級に 10 人の二㔹かいて, 其 $I, Q$ (知 能示数) 沗 $125,103,100,94,89,77,80$, 101, 127, 130 であつた. 77〜130で Mi, 103.3 である. 其学校の 1943 以來の Mi は 98 で,

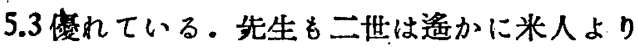
優れていると云つたそうである，象も解二世 は米国に於ての調查成績は極めて優秀なもの である。

\section{2. 二世の性格に就て}

性格の調查として最も多人数に就て調查し た. K. M. Murdoch のものと.M. L. Darsie のものを表示した。両者結果は著しく違つた ものである. Murdoch 氏のものは日本人は 総てに於て白人よりる良く，殊に乘順なるこ

各人種別德義心テスト（12 お） Murdoch. 1925.

\begin{tabular}{|c|c|c|c|c|c|c|c|c|}
\hline \multicolumn{9}{|c|}{ （白人 median 50 として） } \\
\hline & 白 & 人 & 日本人 & 支那人 & 朝 鮮 人 & ハワイ人 & $\begin{array}{l}\text { ポ } \\
\text { ガ } \\
\end{array}$ & 几ト \\
\hline Honesty. 正值 & & 50 & 99 & 87 & 47 & 69 & & 43 \\
\hline Ambitfon 野心 & & 50 & 62 & 70 & 46 & 29 & & 16 \\
\hline Perseverance 不橈 & & 50 & 50 & 63 & 48 & 47 & & 28 \\
\hline Trustworthiness 信用 & & 50 & 50 & 63 & 48 & 47 & & 28 \\
\hline Self-assertion 自己主張 & & 50 & 27 & 29 & 26 & 14 & & 45 \\
\hline $\begin{array}{l}\text { Sensitiveness to public } \\
\text { opinion 舆論に敏感 }\end{array}$ & & 50 & 71 & 68 & 97 & 24 & & 31 \\
\hline Control of emotion 情緒の調篩 & & 50 & 99 & 65 & 38 & 35 & & 33 \\
\hline
\end{tabular}


二世及び米白人性格比較（10〜13 き) Darsie. 氏表

（最大 $=1$ median $=7$ 最小 $=13$ ） 米人 266 , 二世 242

\begin{tabular}{|c|c|c|c|c|}
\hline & $=\quad 世$ & 米白人 & 差 & $\begin{array}{c}\text { Critical } \\
\text { Ratio }\end{array}$ \\
\hline 働く力量 Amount of physical energy. & 6.84 & 6.53 & -0.31 & 2.3 \\
\hline 樑 㢆 Prudence and forethought. & 7.08 & 7.07 & -0.01 & 0.1 \\
\hline$\triangle$ 自 信 Self-confidence. & 7.16 & 6.16 & -1.00 & 7.6 \\
\hline 意力と涊耐 Will-power and perseverance. & 6.56 & 6.40 & -0.16 & 1.2 \\
\hline 。美 鑑 賞 Appreciation of beauty. & 6.54 . & 6.81 & 0.27 & 2.4 \\
\hline$\Delta$ 樂 天 Cheerfulness and optimism. & 6.36 & 5.57 & -0.79 & 6.9 \\
\hline 天氣やでない Permanence of moods & 6.20 & 6.19 & -0.01 & 0.1 \\
\hline 友達の人氮 Popularity with other children & 6.84 & 6.55 & -0.29 & 2.5 \\
\hline 氣に入るよう心境い Sensitivity to approval & 6.78 & 6.24 & -0.54 & 4.3 \\
\hline ○野 心 Desire to excel. & 6.20 & 6.23 & 0.03 & 0.2 \\
\hline - 虚榮の心配なし Freedom from vanity. & 5.94 & 6.09 & 0.15 & 1.2 \\
\hline$\Delta$ 同情心 Sympathy and tenderness & 7.18 & 6.24 & -0.89 & 8.1 \\
\hline$\triangle$ 利已的でない Generosity and unselfishness & 6.96 & 6.42 & -0.54 & 5.2 \\
\hline 良心 的 Conscientiousness & 6.44 & 6.15 & -0.29 & 1.5 \\
\hline$\Delta$ 信 賴 Trustfulness & 6.68 & 5.86 & -0.82 & 6.3 \\
\hline - 技 功 Mechenical ingenuity. & 6.76 & 5.91 & 0.15 & 1.3 \\
\hline$\triangle$ 知識憼 Desire to know & 7.62 & 6.43 & -1.19 & 6.0 \\
\hline 獨 創 力 Originality & 7.56 & 7.07 & -0.49 & 2.6 \\
\hline 知 能 General intelligence & 7.24 & 6.35 & -0.89 & 7.1 \\
\hline
\end{tabular}

と，感動を良く抑制する等最も優れている。 自己主張に於てのみ著しく惡いが，自己主張 は余り强くない方が良いとすれば紷て優れて いることになり，次で支那人か良く朝鮮人は 白人より概して惡く，ポルトガル人最も惡く， 次でハワイ人となつている。

然るに Darsie の成續では表で見るように， 日本人の優れているものは（○印を附け，劣 つたもに 賞，野心，虚栄心の少なきこと等の四つのみ で有意義の差を示したものはーつもない，只 僅かに差の高いものは技巧と美鑑賞のみであ る.反之米白人の優れたものは皆有意義の硈 を示したものである・主なものを挙げると日 本人は自信力の少ないこと，悲観的內行的の 考方方, 同情心, 博愛心の少なきこと, 正直 でないこと，利己的であること等を挙げてい る。両都で最も差を示しているのは前者は日
本人は白人と等しく正直であるとなし，後者 では白人ょり惡くなつている．何れが正しい か判らない. Strong 氏は又市の手形交换 を調へて 日本人は白人よりも支执䓕で遅延し たものが少なく優つている，他は大体同して ある.支那火は略同しであつたと。

ロスアンジルス區手形交換（Strong）

\begin{tabular}{|c|c|c|c|}
\hline & $\begin{array}{c}\text { 日本人 } \\
\%\end{array}$ & 日 人 & 支那人 \\
\hline 手形割引せしすの & 27.1 & 27.8 & 28.9 \\
\hline 支拂正確なりしもの & 41.6 & 40.3 & 43.5 \\
\hline 支拂打そきもの & 23.3 & 21.4 & 19.2 \\
\hline 支拂甚だおそくなりしあの & 8.0 & 10.5 & 8.3 \\
\hline
\end{tabular}

描画法で白人と二世を比較すると，比例の 認識，色の選択は二世の方か優れているか， 総合して二世は白人のノルムょりやろ下る(り みであると云う。

職業の迩択を白人と比較すると余り差かな 
い. 教育程度により美はあるが其相関々係も 0.71〜0.94である. 概して日本人は学校先生, 百姓，医師，建築，技師を希望して，新聞記 者, 保險員, 商人, 宣伝員, 法律家等を希望 しないと云う。

\section{3. 二世の作業能カに就て}

A. 另量 ハワイで S.P. Porteus 氏が 1931 年に大学及び高等学校学生 466 名の 各人種に つき力量の調查したものか，次裴である。沫 れで見るように日本人はフキリッビン人に次
で惡い。これは R.G. Bernreuter 氏の成續も そうであつて終りからら番目であつた。民は これは日本人は筋肉容積自体も少ないのであ るから止むを得ないことである。しかるに工場 ての成績は正反奶で日体人は最㗏である。こ れは，工場での働きは知能及び性質，才能が 力量より大切であるからであることをも証明 一するものであると. 又最近のロ市でのオリン ビック競技で水泳等に優勝したのを見ると， 力量は劣つていても競技には練習と技術勇気 等が必姴であると思うと結んでいるがこの

A 表 力 量 試 驗 Strength Test. (Porteus. S.D). 1931

\begin{tabular}{|c|c|c|c|c|c|c|c|c|}
\hline & 右揘力 & 左 暒 $\begin{array}{c}\text { 力 } \\
(\mathrm{kg})\end{array}$ & $\begin{array}{r}\text { 肺 活 量 } \\
\left(\mathrm{in}^{3}\right)\end{array}$ & $\begin{array}{r}\text { 猆能力 } \\
(\mathbf{k g})\end{array}$ & $\begin{array}{c}\text { 背脚笳力! 身 } \\
(\mathrm{kg}) !\end{array}$ & 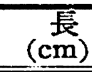 & 力量荼 & No \\
\hline フキリッピン人 & 44.4 & 42.2 & 177.0 & 138.3 & $172: 6$ & 159.6 & 397.5 & 107 \\
\hline 日 本人 & 46.0 & 41.9 & 207.2 & 118.5 & 192.8 & 161.5 & 399.5 & 86 \\
\hline オーストラリヤ & 46.6 & 45.3 & 180.0 & 139.0 & 201.0 & 169.5 & 4320 & 108 \\
\hline 那 & 50.0 & 45.3 & 211.1 & 123.2 & 220.2 & 166.8 & 438.7 & 52 \\
\hline 白人（大學生） & 54.0 & 48.6 & 277.0 & 139.3 & 242.7 & 175.8 & 484.6 & 35 \\
\hline$\therefore \nabla 1$ 人 & 53.5 & 48.5 & 228.9 & 138.3 & 252.8 & & 493.1 & 78 \\
\hline
\end{tabular}

B 表 二世と米白人モートル熟練試驗（高等學校學生）Motor Skill

\begin{tabular}{l|c|c|r|r|r|r}
\hline & $\begin{array}{c}\text { Koerth } \\
\text { Pursuit Rotor }\end{array}$ & $\begin{array}{c}\text { Motor } \\
\text { Rhythmus. }\end{array}$ & $\begin{array}{c}\text { Seeshore serial } \\
\text { Discrimeter }\end{array}$ & $\begin{array}{c}\text { Speed of } \\
\text { Tapping }\end{array}$ & $\begin{array}{c}\text { Brown Spool } \\
\text { Packer }\end{array}$ & $\begin{array}{c}\text { Miles Motility } \\
\text { Rotor }\end{array}$ \\
\hline 二 世 & 1.577 .3 & 597.8 & 1.074 .1 & 224.4 & 564.2 & 1.714 .8 \\
白 人 & 1.549 .9 & 818.6 & 982.5 & 208.2 & 531.7 & 1.630 .0 \\
差 & 27.4 & -221.8 & 91.6 & 16.1 & 32.5 & 84.8 \\
Critic. & 0.3 & 3.7 & 3.3 & 4.1 & 3.9 & 3.7 \\
ratio & & & &
\end{tabular}

C 表 調篩及び反射速度試驗 (秒時) Co.ordination and Reaktion Tests

\begin{tabular}{|c|c|c|c|c|c|c|}
\hline & $\begin{array}{l}\text { 年令又は } \\
\text { 平均年令 }\end{array}$ & $\begin{array}{l}\text { Finger } \\
\text { Coordination }\end{array}$ & $\begin{array}{l}\text { Finger } \\
\text { Reaktion } \\
\text { Pressing } \\
\end{array}$ & $\begin{array}{l}\text { Finger. } \\
\text { Reaktion } \\
\text { Lifting } \\
\end{array}$ & $\begin{array}{l}\text { Right Foot } \\
\text { Reaktion } \\
\text { Lifting } \\
\end{array}$ & $\begin{array}{l}\text { Right Hand } \\
\text { Coor- } \\
\text { dination }\end{array}$ \\
\hline 二世(高校生) & 16.1 & 0,262 & 0.152 & 0.168 & 0.181 & 1.090 \\
\hline 白人（"I） & $12 \sim 19$ & 0.143 & 0.211 & 0.224 & 0.231 & 1.168 \\
\hline 堒 & & -0.119 & 0.059 & 0.056 & 0.050 & 0.78 \\
\hline D/P.E.d & & 12.5 & 5.2 & 4.6 & 4.1 & 2.7 \\
\hline 二世(大學生) & 22.8 & 0.254 & 0.143 & 0.149 & 0.166 & 1.05 \\
\hline 白人（"1） & $18 \sim 34$ & 0.110 & 0.194 & 0.204 & 0.208 & 1.126 \\
\hline 差 & & -0.144 & 0.051 & 0.055 & 0.042 & 0,076 \\
\hline D/P.E.d & & 28.8 & 8.8 & 11.0 & 9.3 & 2.9 \\
\hline
\end{tabular}


試驗の人は身長本均 $161.5 \mathrm{~cm}$ と云うと二世 でも大㚆小さい人であるから力量を小さく出 たものと思われる。

B. 作業能力 白人に比して丁埸に於て熟練 エには日本人は甚だ少ない。然るに日本人に は科学者としては賞金を得又は成功者がある のは一見矛盾しているように見える。究こで 日本人は精密機械に適与るのか，“適せないの かを試驗するために， 高等生 76名，大学生 43 名と白人同級のもの 70 名を比較したるの である. 此機栈は R.H. Seashore 創案のも ので巳に多数の実驗を行い， 白人での標準值 を出ており，方々のこの種試驗に応用されて いるものである。 B.A. Reed, Campbell 氐 等の調查したものである．試驗の目的は㠊密 な読み方，敏活，迅速な制断，電話により鍵 を手早く打つこと等であるか詳細な技術は明 らかでないので表には原語のまるを記した.表 で見るように，2番目は日本人の劣つたもので あるが，それは一つだけて皆日本人か優れて いる。それで日本人は敏活で精密を必要とす る作業に決して適しないのではない，今迄の 熟練工の少さいのは他の理由であるとしてい る. (B 表)

C. 反応速度 W.R. Miles 氏の創案に低る 反応速度测定法により前項と同一人につき調 查したものである．本测定法も屡々米国で使 用されるものである，鍵を打ち，ベンを第一 の穴から第二の穴に移し，一定のボタンを押 す等の働作である。前表で見ると二世は圧倒 的に優秀で，殊に反射速度にも調節にも白人 を凌駕しているのを見る。(C表)

D. 任事振 引 Strong 教授か; 千通の質閣状 を㕍主に差出し 342 の返信を得た其結果を総 括じたものか次表である。之れで見ると日本 人は谌だ優秀であって，㕍主から点に満足し て使うもの及び満足したもの室內で 91\%で， 室外で 73\% で白人ょり㗹秀なのみならす，能 秉不良のため解㕍したものは室內では白人の
1/6, 室外で $1 / 3$ である。（D 表）

$$
\text { D 表 }
$$

履人として日本人と米人との比較％(Strong)

\begin{tabular}{|c|c|c|c|c|}
\hline & 室 & 內 & 室 & 外 \\
\hline & 日本人 & 米人 & 日本人 & 米人 \\
\hline 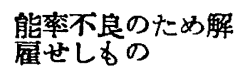 & 2 & 13 & 5 & 17 \\
\hline $\begin{array}{l}\text { 良いのがないため } \\
\text { 一時雇つた }\end{array}$ & 5 & 11 & 2 & 7 \\
\hline 中 位 & 2 & 17 & 20 & 15 \\
\hline 滿足したもの & 29 & 17 & 40 & 17 \\
\hline 萬點に满足したるの & 62 & 42 & 33 & 44 \\
\hline
\end{tabular}

份人種别的に能率及び信用度を調查したも のによると，日本人は最伾位にあつて独逸人 より良く，次で米人で，カナタ人性最下位に なっている。(E 表)

\section{4. 二世の犯罪率に就て}

Stanfort 大学 E. K. Strong (1933) は犯 罪について次の調查がある.F表に就て見る如 く少年犯罪者の率は他民族 の $1 / 4$ 1/6 であ

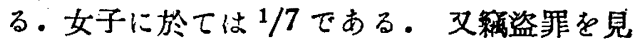

表 E、 (Strong) 氏表 室內作業の能率及び信賴度

\begin{tabular}{|c|c|c|c|c|c|c|c|}
\hline \multirow{2}{*}{ 人 } & \multirow{2}{*}{ N. } & \multicolumn{2}{|c|}{ 能 } & 秉 & \multicolumn{2}{|c|}{ 信 賴 } & \\
\hline & & $\begin{array}{l}\text { 㱔均 } \\
\text { 點 }\end{array}$ & & & & $\begin{array}{l}\text { F良 } \\
\%\end{array}$ & 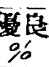 \\
\hline スコットランド人 & 15 & 4.6 & 7 & 80 & 4.8 & 0 & 80 \\
\hline 丁抹及瑞西人 & 66 & 4.5 & 0 & 64 & 4.6 & 3 & 72 \\
\hline 日本 & 86 & 4.4 & 2 & 62 & 4.7 & 0 & 66 \\
\hline フキンランド人 & 35 & 4.3 & 6 & 63 & 4.7 & 3 & 74 \\
\hline 獨逸 & 59 & 4.1 & 8 & 54 & 4.5 & 3 & 70 \\
\hline 支 那 & $51^{i}$ & 4.1 & 6 & 45 & $\therefore 4$ & 2 & 53 \\
\hline 黑 & 70 & 4.1 & 9 & 51 & 4.2 & 3 & 43 \\
\hline アイルランド人 & 41 & $4.0^{\prime}$ & 7 & 51 & 4.4 & 2 & 63 \\
\hline フキリッピン人 & 25 & 3.9 & 0 & 28 & 4.0 & 4 & 19 \\
\hline 英カナダ人 & 30 & 3.8 & 10 & 47 & 4.3 & 0 & 60 \\
\hline 米 $\quad$ 人 & 147 & 3.6 & 12 & 41 & 4.3 & 2 & 57 \\
\hline 均 & & 4.1 & 7 & 50 & 4.4 & 2 & 59 \\
\hline
\end{tabular}


表 F. 青少年の過失犯罪者（ホノル、1913 〜1928）10１7才 男子

\begin{tabular}{|c|c|c|c|c|c|c|}
\hline \multirow{2}{*}{ 年 次 } & \multicolumn{3}{|c|}{ 日本人以外 } & 日 & 本 & 人 \\
\hline & \multicolumn{3}{|c|}{ 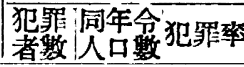 } & \multicolumn{3}{|c|}{ 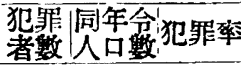 } \\
\hline 1913 & 371 & 3,209 & 1,156 & 49 & 876 & 559 \\
\hline 1918 & 324 & 4,007 & 809 & 41 & 1,303 & 315 \\
\hline 1923 & 260 & 5,098 & 510 & 30 & 2,322 & 129 \\
\hline 1926 & 160 & 5,870 & 273 & 17 & 3,170 & 53 \\
\hline 1927 & 228 & 6,128 & 372 & 25 & 3,452 & 72 \\
\hline 1928 & 256 & 6,385 & 401 & 26 & 3,735 & 70 \\
\hline 全信 ${ }_{1928}^{1917}$ & \multicolumn{2}{|c|}{$2,82060,221$} & 468 & 369 & 27,349 & 135 \\
\hline & \multicolumn{3}{|c|}{ 女 } & \multicolumn{3}{|l|}{ 子 } \\
\hline 1913 & 88 & 3,075 & 286 & 3 & 826 & 36 \\
\hline 1918 & 61 & 3,819 & 162 & 7 & 1,235 & 57 \\
\hline 1923 & 53 & 4,861 & 109 & 4 & 2,240 & 18 \\
\hline 1926 & 86 & 5,606 & 153 & 7 & 3,080 & 23 \\
\hline 1927 & 90 & 5,855 & 154 & 7 & 3,360 & 21 \\
\hline 1928 & 89 & 6,103 & 146 & $\cdot 3$ & 3,640 & 8 \\
\hline 1929 & 101 & 6,352 & 156 & 11 & 3,920 & 28 \\
\hline 全計 ${ }^{1917}$ & 419 & 69,389 & 132 & 79 & 34,507 & 23 \\
\hline
\end{tabular}

ても $1 / 4 \sim 1 / 7$ であこと次表 $\mathrm{H}$ の通りであ る.

表 H. 籍犯罪者, 男子, ホノ几、1913 28

\begin{tabular}{|c|c|c|c|c|c|c|}
\hline \multirow{2}{*}{ 年 } & \multicolumn{3}{|c|}{$\begin{array}{c}\text { 日 本人 以 外 } \\
(10 \sim 17 \text { 手) }\end{array}$} & 日 & 本 & 人 \\
\hline & 盜罪數 & $\begin{array}{l}\text { 同年令 } \\
\text { 人口 }\end{array}$ & 犯罪 & 盗罪數 & $\begin{array}{l}\text { 同年令 } \\
\text { 人口 }\end{array}$ & $\begin{array}{l}\text { 犯罪 } \\
\text { 茶 } \\
\end{array}$ \\
\hline 1913 & 83 & 3,209 & 255 & 12 & 876 & 137 \\
\hline 1918 & 123 & 4,007 & 307 & 12 & 1,303 & 92 \\
\hline 1927 & 133 & 6,128 & 217 & 17 & 3,452 & 49 \\
\hline 1928 & 162 & 6,385 & 254 & 13 & 3,735 & 35 \\
\hline 全計 ${ }_{1928}^{1917}$ & 1,296 & 60,221 & 215 & 144 & 27,349 & 53 \\
\hline
\end{tabular}

ロスフンヂルス市に於て青年犯罪率を各人 種別に調查したものか㳄裴Iでこれで，見れ ば, 日本人，支那人最も優良で，米人は其 4 倍 になり，最も惡いのは黑人である。
表 I. 人種別の青年犯罪率 (Los Angeles.)

\begin{tabular}{|c|c|c|c|c|c|}
\hline \multirow{2}{*}{ 人 } & \multirow{2}{*}{ 犯罪較 } & \multirow{2}{*}{\multicolumn{2}{|c|}{$\begin{array}{l}\text { 18才以上 } 1930 \\
\text { 人口調查小學校 } \\
1929\end{array}$}} & \multicolumn{2}{|c|}{ 犯罪率對千 } \\
\hline & & & & 1929 & 1930 \\
\hline$\gamma \times$ 况 & 2,043 & 235,580 & & 8.7 & \\
\hline 黑 & 374 & 6,973 & & 53.6 & \\
\hline 支 那 人 & 2 & 1,031 & 783 & 1.9 & 2.5 \\
\hline 日本人 & 19 & 8,682 & 7,290 & 2.1 & 2.6 \\
\hline 伊太利人 & 220 & & 6,834 & & 32.1 \\
\hline x $\neq=$ 三人 & 963 & 40,646 & & 23.6 & \\
\hline フキリッピン人 & 6 & 486 & & 12.3 & \\
\hline - $シ ア 人$ & 56 & & 2,110 & & 26.5 \\
\hline スペイン人其他 & 1,055 & & 39,099 & & 26.9 \\
\hline
\end{tabular}

A.W Lind は青年犯罪载判例及び比率を人 種別に調查したものは次の如くであつた。

この J 裴で見ると一番犯罪の少ないのは白 人で, 次で日本人で支那人は其 2 倍以上, 朝鮮 人は6倍である。欧州白人でもボルトガル人 は日本人の 5 倍で，フキリッピン人は9倍に も垂んとしている。最も惡いのはハワイ土人 である。茹に下記の各表に日本人と日うのは， 青年と日うのであるから大体二师であると思 われる。 ハワイは総て二世の㐫でも良くない

表 J. ホノル、とて青年裁制例數及び犯罪率 (1926 1928) (Lind)

\begin{tabular}{|c|c|c|}
\hline 人 種 別 & 裁制 例 数 & 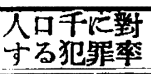 \\
\hline 八 $\nabla 1$ 人 & 208 & 169.7 \\
\hline Part Hawain 人 & 176 & 46.9 \\
\hline 水ルガ 人 & 173 & 65.1 \\
\hline Port Rican 人 & 51 & 167.1 \\
\hline ス ペ 1 人 & 7 & 46.3 \\
\hline 其他の白人 & 26 & 10.7 \\
\hline 支 那 人 & 114 & 26.8 \\
\hline 本 & 106 & 12,1 \\
\hline 朝 鮮 人 & 43 & 72.8 \\
\hline フキリッピン人 & 49 & 108.1 \\
\hline 全＼cjkstart計 & 960 & 38.3 \\
\hline
\end{tabular}

のが多いから，北米本土の方では白人と同率 或は夫れ以上良いのであ万ちと思われる。

Beach 氏はカルホル ニ゙ャてて 1900〜27 年間 
の大小全部の犯罪から過料まで総てを調べ其 総数 2,037,794 中（支那人は全米人口 $1.5 \%$ ， 日本人は $1.7 \%$ で支那人の方が少ないが）犯罪 率は支那人 $3.5 \%$ ，日本人 $0.9 \%$ であるから日 本人の方か $1 / 4$ の犯罪率であると，(これは日 本人として調查したので二世とは限らないら (w)

San Quetin 及び Folsom 両州の犯罪数 65.919 件中其人口に対する比率を見るに，支 那人 $1.6 \%$ ，日本人 $0.2 \%$ で $1 / 8$ であるが，且.支 那人には重罪すあるか， 日本人には微罪のも のが多数であるのみならす詳細に人口樥成か ら見るとこの数字以上に日本人の方か：良い理 となると，斯く日本人は犯罪加ら見ると他の 民族より a fine record を示したと結論して いる。

月号释來潮年令は伊藤，須々木氏の研究によ 几ば二世は 13 才 1 月（10〜18才）で日本声人 の 14 才 3.8 月に比し 14.8 月早く同地白人の 12 才 11 月より 2 月おくれている，血压は队地姑 人と.同しである.(收縮 68.6, 拡張 $11.6 \mathrm{~mm}$ )

\section{芽6 菂 總括}

1. 身長及び体重 二世は日本人に比し出成 時巳に大きく，発育に供い其差著しく，成人 に於て身長 5 9 粴 $(4.8 \%$ 5.8\%) 大きく， 体重に於ても 9 12 狂 (17\%) 重い.今夫等の 発充曲楾を見ると警く程米人や欧人と同じで ある (1，3図). しかし夫れは 15 方 (男子)ま でら，夫れから成人までに米人は引き続き 12.8 糎伸びるが日本人は $7.3 \mathrm{~cm}$, 二世怈 9.4 糎 しか伸びない（女子は 13 才まで同じで，そ れから米人は 16.4 糎伸び，日本婦人は $7.2 \mathrm{~cm}$, 二世仙 8.5 糎しか伸びない)。体重に於てもそ の関係は同じである。人種的の差であろうか。 (1, 3 図)

同じ二世の內でもカルホルニャ産れ最す儑 れ，次で他州，次でハワイで，日本に一定期 間育つた人は最す劣る。

月释來潮の年令も二世は 13 年 1 月で，內地 人ょり 14.8 月も早いか，白人とは殆んと等し く僅かに 2 月おくれるた゚けである。
米国以外の 殖昌地二世の身長は满洲の二世: は內地人とほゔ同大で，比島は 1.5 粧位小さ

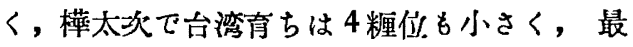
も劣つているのは南洋諧島である. (4, 5 表)

2. 米国㕕ち二世の 7 才から 17 才までの年 々の発充萃曲楾を見ると, 日本人男子は 10 才 から13才までの間の発育か:二世より著しく幄 れている.女子に於ては10才から12才，殊に 12 才で二世や米国人は大きな山築くのに，

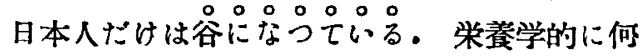
か人陷があるのではなかううか。(4図)

3. 一番琹を示したのは皮厚であつた。 二世 は日本人にくらへ $123 \%$ す厚いのに驚く,次で は上正脯囲の $13.5 \%$ 優秀なことである。皆共に 栄䓹の優秀さを証明するすのであるか，特に 上膊囲の差は筇肉の銀鍊を物語るるのである。

4. 穴肢長と坐高 二世の下肢長は $2.7 \sim 8.3$ 糎長く此下肢長す五著者皆高くなつている 〔2.7\% (石), $2.7 \%$ (須), 0.7 (邻) , $2.0 \%$ (Sh)， 우 0.3 (伊) ].

反之比坐高は觜低くなつている〔1.5\%(㮌)， $1.2 \%$ (飯)，0.7\% (Sh)， +0.3(伊)]. 即古下䁌 長が長くなつたらけ坐高か縮んでいた。皇こ で日本內地人と略同身長の二世を調べて見る そ，下肢長は $0.9 \mathrm{~cm}$ 伸びているか：坐高は 1.1 cm 縮んでいると日る事実を見た。下肢長の 伸びたことは栄養の骤良さに任つて說明もつ くか，坐高の縮んだこと㳊䚴されない，日 本の坐居か下肢長の伸長孝抑制し，却つて坐 高が伸びたのではあるまいか，生物は一方の 発育を抑制されると，他方に伸びる現象は常 に見ることであるからである。(19表)

新生児で二世と日本人との下肢長は同しで あるが，白人の下肢長より共に長い。発育 3 才で白人の方が長くなる。

胎児の上肢長は下肢長より長く胴は短かい。 猿は生涯そうである。（人は出生後其伸び方か； 人積によつて違う。ネグロは坐高が短く下肢 
長も長いが上肢長特に前膊が長い，白人は生 れた時た下䁌長より上肢長か長いか２２ 3 年で 下肢長の方が長くなる。此坐高も生れたては 高いがすぐ低くなる。日本人は生れたて上肢 長より下肢長の方が長いが仰び方が 小さく短 い, 比坐高も一番高くなる。亗いつでも 白人と日本人との中間で発育する。

5. 頭示数 二世は出产直挠は日本人を同し であるが，後頭幅大きくなり (約 7 粍), 頭 示数平均 85.21 (日本人平均 80.7) になる.分布 率を見ても過短頭型 $49.6 \%$ の多数である。 シ ヤバイローのハワイ二世の頭示数は 83.8 とな り，汀口氏及び塚田氏の南洋の二世は共に 84 前後を示している．ボフス氏は欧人の米国育 ち二世の頭示数の変化を唱えているのである. 栄食と移民によつて変るるのと思はれる・

6. 二世姑斯く身長, 下肢長は伸び, 坐高鼻 幅, 観骨幅小縮小, 肩幅, 比指極, 胸囲は增 天，鼻示数，顏示数は小さくなることは白人 に近つくが，頭巾增大，腰巾，上肢長短縮・ 肢間示数は減小!白人に遠ざかつている。

7. 上肢長は二世は短い, 全米二世の平均比 上肢長に於て $0.8 \%$ 小であり，日本人と同身 長の二俈と比較すると実数に於て 1.0 粧小さ く，比上肢長に於て $0.6 \%$ 小である. 何故て あるか說明に苦しむ，或は坐高の短くなつて いるのに比例したものかもしれぬ。

$\frac{\text { 上胶長 }}{\text { 示 数 }}=$ 示数を見ると新生児です成人て も,二世と日本人とは同じ割合にあることを 見るからである・(22表C)

以上は過去 5 ヶ年に涉る研究で，兹に緾め 得て感なき能はすである。蓋し一は遺伝因子 の結合に位る変化，一は移民環境に依る変化 で両者自ら別である。皮膚や筡の色彩や血液 型其他の示数の変化は混血にのみ位つて変る ものである。然るに骨格の示数の如きるのは 良く移民に依つて変るのを見たのである。二 拉は斯く体位に弪れているか;知能示数，性 格，作掌能力，德義心，犯罪数等他の民族よ
クッッット優れているのを見た（A-J 表).一番 の欠陷である栄食を改善すれば体育知育共に 優秀な民族たる天賦の素質を保つている。日 本民族の体育と知育改善に資することもあら ば至幸である。

\section{主要文献}

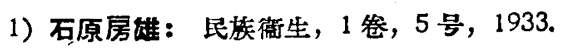

2) 石原房雄：日本医事新報，1324 号，1949.

3) 須々橩：果京影徽鏡学会猚誌，40卷，2号. 体育研觉，5然，5,6号，(沿和 13 年)。 民族衙生, 16 卷, 2 号, (妿和 24 年).

4) 吉田章倍：社会医学䧴誌，466, 467 号，（大 正14 年 11 12月).

人口閣題研究㗄料, 59 号, (1950).

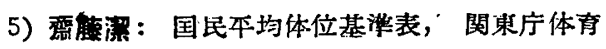

6) 關東歷体育旺究所：日满兒望の調楂，(㗁和 7 年).

7) Paul, K. Ito.: American Jaurnal of diseases of children Aug. 1936. Vol. 52.

8) Paul. K. Ito.: Human Biology, Vol. 14, No. $3,1942$.

9) 玉并芳幸: 人類学, 人類造伝学体犋学論文 集, (登応大学医科解剖学数室, 谷口教授編), 10 册, 7 册.

10) 塚田勝: 人類学, 人類遗伝学体質学論交集, 10 册, 4 册.

11) 野田一夫：人類学, 人類造伝学体質学 論交 集, 3 册.

12）中澤䉆司： 人類学, 人類遇伝学体質学論交 集, 11 册.

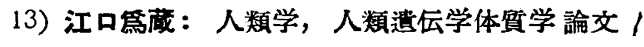
集, 1 册.

14) Stratz, C.H.: Der Körper des Kindes. Stuttgart.

15) Collins, S.D and J. Clark: Physical measurements of boys and girls of Native white race Stock in the United States, Public Health Report 44, 1083. May, 1929.

16) Fridenthal: Allgemeine u. Spezielle Physiologie d. Menschenwachstum. 1914. Berlin.

17) Taylor, Rood: Measurements of 250, Full Jerm. New. Born Infants: Am. J. Dis. Child. 17: 355, May, 1919. 
18) Riggs: Obstetrics, 5, New York.

19) A. W. Lind.: American Journal of Sociology. XXXVI. 215. 1930.

20) E. K. Strong.: Stanford University. Press. 1933.

21) W. G Beach: Stanford University. Publications. Vol. 111 No. 3. 1932.

22) T. Fukuda: American J. of Psychology XXXIV 599-601 及び 30, 1923.

23) M. L. Darsie: Comparative Psychology Monographs Vol. 11l. No. 15. January 1926.

24) 田中空一：東京文理科大学文科紀要, 19 卷, 昭和 16 年, 12 卷, 14, 15, 17 卷.

25) Murdoch and Sullivan: American Physical Education Review XXVIII 1923.

26) P. Sandiford and R. Keer: J. of Educat. Psycholog. XVII. 1926.
27）神㥓 K : Ann. of. American Academy of Political a. Social Science, Vol. XCII. 1921.

附

幼児（1６才）の体位測定値

飯高歲子

本編は度応大学谷口教授指導の許に石原援 助の下に行つたものであるが，混血児と日本 人とを比較するに日本人の幼児の各部位の测 定値無き為め行つたもので,其比較に便ならん と特に妶に記す。原著は不日谷口教授編人類 学，体質学論文集に詳述する。测定人員 514 名で東京都內幼児である。

倨本研究は厚生直人口問題研究所の委託研究で ある。 


\title{
A CONTRIBUTION TO JUDGMENT OF. SOCIAL PROGNOSIS FOR OFFENDERS
}

By

\author{
Ikdo YonekdRa and Genicht Naka.jika
}

About 220, random-sampled, offenders discharged from the Nagoya prison between 1948 and 1949 were followed up until March, 1952 as to their conduct; and tried to evaluate the relative importance of 19 biological and sociological factors.

Out of these offenders 78 violated again after from 26 to 42 months.

It was found with these 78 violators and 192 nonviolators by statistcal test that the following 9 factors were significant on the judgment of social prognosis for offenders :

1) Hereditary disease of kin

2) Family trouble

3) Misconduct before 18 age

4) Serious illness and wound

5) No protector

(Above, less than $1 \%$ of the level of significance)

6) Incomplete compulsory education of parent

7) Prison punishment

8) Psychopathy

9) No occupational aptitude

(Above, less than $5 \%$ of the level of significance)

(Seto Refarmatory and Gifu Mental Institution)

\section{A COMPARATIVE STUDY OF BODY STRUCTURE OF NISEI AND OF NATIVE JAPANESE}

By

T. ISHI IIDAKA

1) An anthropometric examination was conducted of 534 so-called Niseis who were born in the United States to parents of pure Japanese stock. As compared with the native Japanese adult, the total length of body of a Nisei is 5 to $9.3 \mathrm{~cm}$. greater and the weight 9 to $12 \mathrm{~kg}$. heavier. As shown in Figure No. 1, the growth curve of the Nisei from 6 to 15 years of age remarkably runs accordant with that of the white American, but after that age the yearly growth in the case of the latter amounts to $12.8 \mathrm{~cm}$. till he becomes an adult, whereas in the case of Nisei and Japanese it amounts to only $5.5 \mathrm{~cm}$. Also the developing curves of body weight show an almost identical curve. The second generation Japanese in other countries, such as the Philippines, Sumatra, Korea and Manchuria, do not show such good records of growth, but fall below those of the native Japanese, by 1 ito $4 \mathrm{~cm}$. in stature and 5 to $10 \mathrm{~kg}$. in body weight. (Table 4.5 . Fig. 1. 3.) 
2) It is quite remarkable that the curve of indices for annual growth of the Nisei between the ages of 10 and 13 runs far above that of the native Japanese, especially in the case of Nisei girls. The white Americans form a peak in the curve at the age of 12 years, in sharp contrast to a deep dent made by the native Japanese at that age. (cf. Figure No.4)

3) The most notable difference between the Nisei and the native Japanese is found in the thickness of skin and the circumference of upper arm. The former of the Nisei is larger by 123 per cent, and the latter by 17 per cent, than those of the native Japanese. Such difference has been caused by the better nutrition and better training of muscles in the case of the Nisei than in the case of the native Japanese. (Table 3.)

4) Leg length and trunk length. On the averge, the leg length of a Nisei is 2.8 to $8.3 \mathrm{~cm}$. greater and its ratio to his stature about 1.00 per cent larger than the corresponding figures for a Japanese, and, on the other hand, the sitting height of Nisei is shorter by about 1.2 per cent. Therefore, for the purpose of our researches, we have sampled out such Nisei and native Japanese as have approximately the same total length of body, and examined their leg length and their sitting height. It has been ascertained that the averge leg length of a Nisei is greater by about $0.9 \mathrm{~cm}$. and his sitting height smaller by about $1.1 \mathrm{~cm}$. than the comparable figures for a native Japanese. It is concluded that leg length of the native Japanese has been shortened, and that their sitting height made taller, as the result of restraint on growth due to the sedentary habit in their daily life. As we often find in living organisms, a restraint on the one part as a rule causes a development on the other. (Table 9. 10. 11. 19. 20. Fig. 2.)

5) Cephalic index. The biparietal diameter of head of the Nisei is larger by about $7 \mathrm{~mm}$. than the Japanese native's, with no variation in the occipitofrontal diameter. Therefore, the cephalic index works out at $\mathbf{8 5}$ for Niseis, as against 81 for Japanese natives on the average. Shapiro already obtained the cephalic index for Niseis in Hawaii, which amounted to 83.8. He also measured native Japanese and obtained figure of 80.1 for them. Eguchi and Tsukada examind the second-generation Japanese in South Sea areas and arrived at a figure of 84 . It is interesting to note that these inquiries of the emigration people have produced approximately similar results. (Table 3. 24. Fig. 6.)

6) To a greater or lesser degree, the breadth of nose, cheak bone, shoulder, as well as intercristal breath of the Nisei is smaller than that of the native Japanese, though with respect to the lengths the former excels the latter. The indices of both nose and face are smaller for the Nisei.

7) It is somewhat surprising to find that the relative arm length of the Nisei is about 0.8 per cent smaller than that of the native Japanese, and that, in the case of those having an equal body length with the Japanese native, the Nisei's total arm length is $1.0 \mathrm{~cm}$ shorter and their relative arm length 0.6 per cent smaller. On the other hand, the ratio of the trunk and totale arm length of Japanese and Nisei showed about same number. (Table 19.)

(Microbic Institute, Nihon Univrsity. Vice Director Fusao Ishiwara) 